\title{
SITE-SPECIFIC STANDARD REQUEST FOR UNDERGROUND STORAGE TANKS 1219-U, 1222-U, 2082-U, AND 2068-U AT THE RUST GARAGE FACILITY BULDINGS 9754-1 AND 9720-15
}

\author{
OAK RIDGE Y-12 PLANT \\ OAK RIDGE, TENNESSEE \\ FACILITY ID \#0-010117
}

December 1994

Environmental Management Department

Health, Safety, Environment, and Accountability Organization 


\section{DISCLAIMER}

This report was prepared as an account of work sponsored by an agency of the United States Government. Neither the United States Government nor any agency thereof, nor any of their employees, makes any warranty, express or implied, or assumes any legal liability or responsibility for the accuracy, completeness, or usefulness of any information, apparatus, product, or process disclosed, or represents that its use would not infringe privately owned rights. Reference herein to any specific commercial product, process, or service by trade name, trademark, manufacturer, or otherwise, does not necessarily constitute or imply its endorsement, recommendation, or favoring by the United States Government or any agency thereof. The views and opinions of authors expressed herein do not necessarily state or reflect those of the United States Government or any agency thereof. 


\section{DISCLAIMER}

Portions of this document may be illegible in electronic image products. Images are produced from the best available original document. 
SITE-SPECIFIC STANDARD REQUEST FOR UNDERGROUND STORAGE TANKS 1219-U, 1222-U, 2082-U, AND 2068-U AT THE RUST GARAGE FACILITY BUILDINGS 9754-1 AND 9720-15

\author{
OAK RIDGE Y-12 PLANT \\ OAK RIDGE, TENNESSEE \\ FACILITY ID \#0-010117
}

\title{
December 1994
}

Environmental Management Department

Health, Safety, Environment, and Accountability Organization

\author{
Prepared by \\ Science Applications International Corporation \\ Under Subcontract 18B-99069C \\ for the \\ Oak Ridge Y-12 Plant \\ Oak Ridge, Tennessee 37831
}

\author{
Managed by \\ Martin Marietta Energy Systems, Inc. \\ for the \\ U.S. Department of Energy \\ Under Contract No. DE-AC05-84OR21400
}


SCIENCE APPLICATIONS INTERNATIONAL CORPORATION

contributed to the preparation of this document and should not be considered an eligible contractor for its review. 


\section{TABLE OF CONTENTS}

Page

LIST OF FIGURES $\ldots \ldots \ldots \ldots \ldots \ldots \ldots \ldots \ldots \ldots \ldots \ldots \ldots \ldots \ldots$

LIST OF TABLES $\ldots \ldots \ldots \ldots \ldots \ldots \ldots \ldots \ldots \ldots \ldots \ldots \ldots \ldots \ldots$ viii

LIST OF ACRONYMS $\ldots \ldots \ldots \ldots \ldots \ldots \ldots \ldots \ldots \ldots \ldots \ldots \ldots$ ix

SIGNATURE PAGE $\ldots \ldots \ldots \ldots \ldots \ldots \ldots \ldots \ldots \ldots \ldots \ldots \ldots \ldots$

CERTIFICATION PAGE $\ldots \ldots \ldots \ldots \ldots \ldots \ldots \ldots \ldots \ldots \ldots \ldots \ldots \ldots \ldots \ldots$

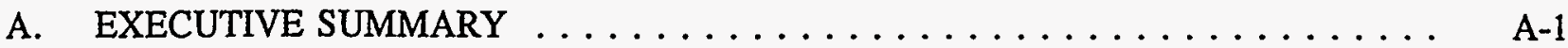

B. Provide the Physical and Chemical Characteristics of Petroleum; Including

Its Toxicity, Persistence, and Potential for Migration . . . . . . . . . . . .

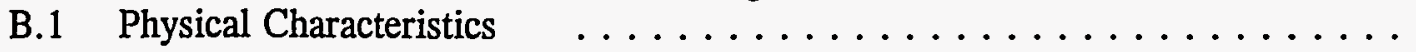

B.1.a The source(s) of contamination and amount released ...........

B.1.b The background level of each constituent in both the soil and groundwater of the area if naturally-occurring petroleum is suspected to exist upgradient of the contaminant plume(s) $\ldots \ldots \ldots \ldots$

B.1.c The media through which the release is spreading or is likely to spread, the direction, and the rate $\ldots \ldots \ldots \ldots$ B-2

B.1.d Site maps showing the contaminant plume(s) defined to the applicable cleanup levels as listed in Appendices 3 and 4 of Rule 1200-1-15 . . . . . . . . . . . . . . . . . . . . . .

B.1.e The results of a Synthetic Precipitation Leach Test (SW-846, Method 1312, July 1992) if BTX soil contamination is present above applicable cleanup levels (Note: The soil sample shall be collected in the area of highest known contamination and analyzed for the groundwater constituents in Worksheets 1 and 2) ........

B.2 Chemical Characteristics

B.2.a A comparison of the constituents by completing Worksheets 1 and 2 (Note: If the released and requested constituent concentrations are the same, only complete Worksheet 1 . If the released and requested constituent concentrations are different, give the rationale for selecting the requested concentrations.) . . . . . .

B.2.b The mobility of each constituent (i.e., solubility in water, ability to move by vapors, absorption by soil, etc.) . . . . . . . . B.2.b.i Gasoline - Benzene, Ethylbenzene, Toluene, Xylene, Methyl Tertiary Butyl Ether, Di-Isopropyl Ether, TPH - Gasoline Range Organics . . . . . . . . . . . .

B.2.b.ii Diesel, Kerosene, Waste Oil, etc. - TPH -

Diesel Range Organics/418.1 . . . . . . . . . .

C. Provide the Hydrogeologic Characteristics of the Petroleum Site and the

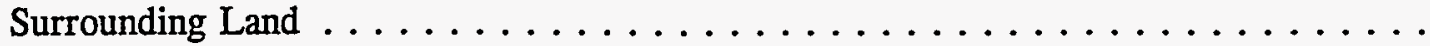

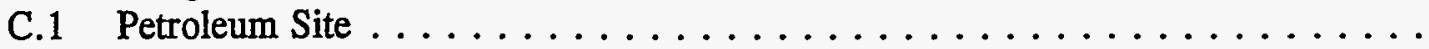

C.1.a The soil permeability as required in Section $E$ of the 
C.1.b and c. Groundwater recharge area and rate $\ldots \ldots \ldots \ldots \ldots \ldots$

C.1.d Hydrology (groundwater flow gradient, direction, and the

occurrence of main aquifers or water bearing zones) . . . . . . . .

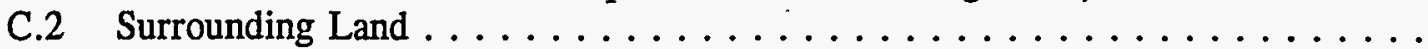

C.2.a and $b$. Groundwater recharge area and rate .............

C.2.c Hydrology (groundwater flow gradient, direction, and the occurrence of main aquifers or water bearing zones) $\ldots \ldots \ldots \ldots$

D. Provide the Proximity, Quality, and Current and Future Use of Groundwater . . . . . .

D.1 The groundwater classification of the aquifer or water source (i.e., drinking water supply or non-drinking water supply)

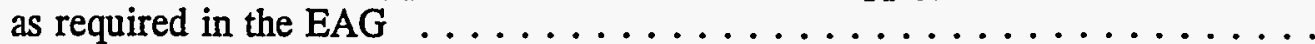

D-1

D.2 Any current and/or future uses of the groundwater within a one-half mile radius of the petroleum site (All well and spring locations shall be indicated on an $8.5 \times 11$ or $11 \times 17$ inch color topographic map.) . . . . . . . . . . . . . . . . .

D.3 The depth to each aquifer or water bearing zone encountered

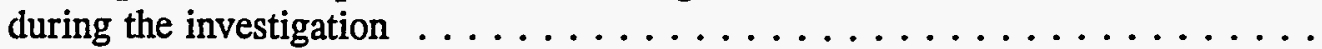

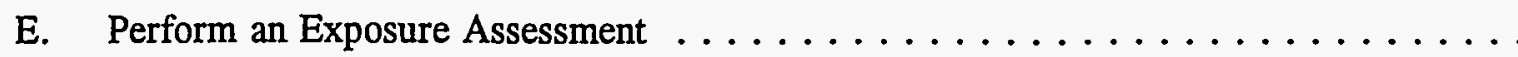

E.1 Potential exposure routes including any future change in land use

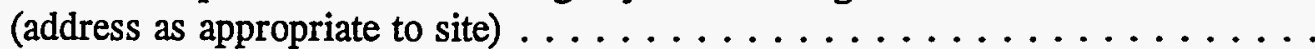

E.1.a Groundwater . .................... E-1

E.1.a.i and ii Oral and Dermal .............. E-1

E.1.b Surface water $\ldots \ldots \ldots \ldots \ldots \ldots \ldots \ldots \ldots \ldots \ldots \ldots \ldots \ldots \ldots$ E-2

E.1.b.i and ii Oral and Dermal .............. E-2

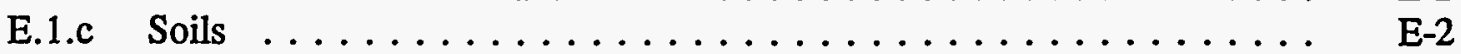

E.1.c.i and ii Oral and Dermal: (I) Surficial (12 ft or less) and (II) Deep (greater than $12 \mathrm{ft}$ ) $\ldots \ldots \ldots \ldots$ E-2

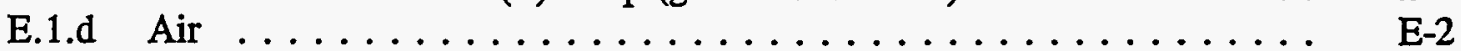

E.2 Potential receptors by exposure route $\ldots \ldots \ldots \ldots \ldots \ldots \ldots \ldots$ E-3

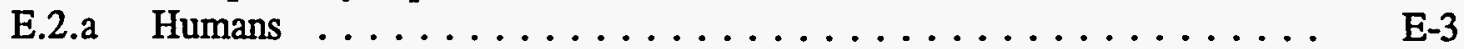

E.2.a,b, and c Domestic species, Aquatic species (plants and wildlife), and Terrestrial species (plants and wildlife) $\ldots \ldots \ldots \ldots$ E-5

F. Provide the Proximity, Quality, and Current and Future Uses of Surface Waters ... F F-1

F.1 Any surface waters within a one-half mile radius and the site location indicated on a color topographic map (This map shall be on

$8.5 \times 11$ or $11 \times 17$ inch paper.) $\ldots \ldots \ldots \ldots \ldots \ldots \ldots \ldots \ldots \ldots \ldots \ldots \ldots \ldots$ F-1

F.2 Any current and/or future uses of surface waters within a one-half mile radius

(i.e., drinking water source, recreation, etc.) $\ldots \ldots \ldots \ldots \ldots \ldots \ldots$ 


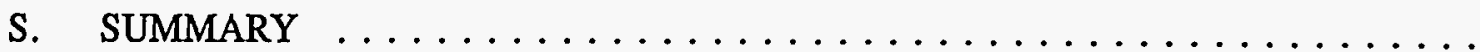

S.1 A summary justifying the proposed site-specific cleanup levels based on

all available information. The summary must include a discussion of the calculations in Worksheets 1 and 2, the information compiled in the exposure assessment, and all risk(s) (carcinogenic, systemic toxicant, and other) to human health or the environment . . . . . . . . . . . . .

S.2 A proposal of the groundwater monitoring wells to be sampled during site status monitoring if the Site-specific Standard Request is approved. Closure monitoring and reporting shall be performed in accordance

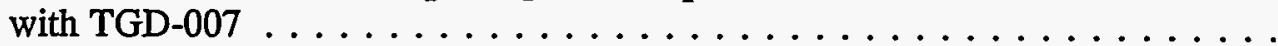

ATTACHMENT A: $\quad$ Site-Specific Standard Request Worksheet $1 \ldots \ldots \ldots \ldots$ A-2 Site-Specific Standard Request Worksheet $2 \ldots \ldots \ldots$ A . . . . .

ATTACHMENT B: $\quad$ ODAST Fate and Transport Modeling Data . . . . . . . . . B-1 


\section{LIST OF FIGURES}

Figure Title

Page

A.1 Location of the Rust Garage Facility at the $\mathrm{Y}-12$ Plant $\ldots \ldots \ldots \ldots$ A-4

A.2 Rust Garage Facility Site Map . . . . . . . . . . . . . . A

B.1 Horizontal Extent of Soil Contamination at the Rust Garage Facility . . . . . . B-9

B.2 Rust Garage Facility Vertical Extent of Soil Contamination

Along Geologic Cross-Section A-A $\ldots \ldots \ldots \ldots \ldots \ldots$ B-10

B.3 Rust Garage Facility Vertical Extent of Soil Contamination

Along Geologic Cross-Séction B-B' ${ }^{\prime} \ldots \ldots \ldots \ldots \ldots \ldots$ B-11

B.4 Rust Garage Facility Vertical Extent of Soil Contamination

Along Geologic Cross-Section $\mathrm{C}^{-\mathrm{C}^{\prime}} \ldots \ldots \ldots \ldots \ldots \ldots \ldots$ B . . . . . . .

B.5 Rust Garage Facility Vertical Extent of Soil Contamination

Along Geologic Cross-Section $\mathrm{D}^{\mathrm{D}} \mathrm{D}^{\prime} \ldots \ldots \ldots \ldots \ldots \ldots \ldots \ldots$ B-13

B.6 Rust Garage Facility Vertical Extent of Soil Contamination

Along Geologic Cross-Section $\mathrm{E}^{\prime} \mathrm{E}^{\prime} \ldots \ldots \ldots \ldots \ldots \ldots \ldots$ B $\ldots \ldots \ldots$

B.7 Horizontal Extent of Benzene Contamination in Groundwater

at the Rust Garage Facility . . . . . . . . . . . . . . . . B-15

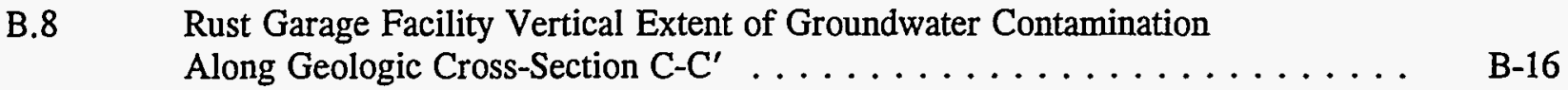

B.9 Rust Garage Facility Vertical Extent of Groundwater Contamination

Along Geologic Cross-Section D-D' . . . . . . . . . . . . B-17

C.1 Hydrogeologic Regimes at the $\mathrm{Y}-12$ Plant $\ldots \ldots \ldots \ldots$ C-5

C.2 Rust Garage Facility Site Groundwater Potentiometric Contour Map,

November $1993 \ldots \ldots \ldots \ldots \ldots \ldots \ldots \ldots \ldots \ldots$. . . . . . . . . . .

C.3 Rust Garage Facility Site Groundwater Potentiometric Contour Map,

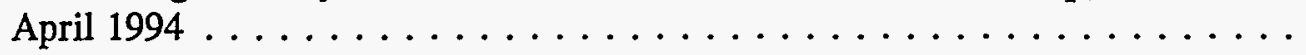

C.4 Conceptual Groundwater Flow Patterns in the Vicinity

of the Oak Ridge $\mathrm{Y}-12$ Plant $\ldots \ldots \ldots \ldots \ldots \ldots \ldots \ldots \ldots$ C-8

C.5 Groundwater Elevations in the Water-Table Interval at the Y-12 Plant . . . . C C 
D.1 Locations of Springs within a One-half Mile Radius of

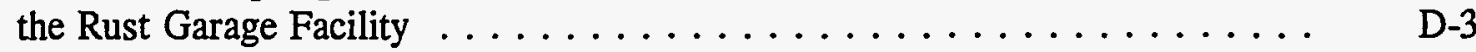

E.1 Boundaries of the Oak Ridge Reservation and the City of Oak Ridge $\ldots \ldots$ E-7

F.1 Surface Water Features Located in the Vicinity of the

Rust Garage Facility . . . . . . . . . . . . . . . . . . F F-2 


\section{LIST OF TABLES}

Table Title $\underline{\text { Page }}$

A.1 Proposed Site-Specific Cleanup Levels for the Rust Garage Facility . . . . . . A-6

B.1 Summary of Soil Analytical Data Generated from Site Investigations

Conducted at the Rust Garage Facility ................ B-18

B.2 Summary of Groundwater Analytical Data Generated from Site Investigations Conducted at the Rust Garage Facility . . . . . . . . . B B

B.3 Parameters Describing Chemical Characteristics of Petroleum

Constituents Present at the Rust Garage Facility ............. . B-34

B.4 Input Parameters Used by ODAST $\ldots \ldots \ldots \ldots \ldots \ldots \ldots \ldots \ldots \ldots \ldots$

C.1 Summary of Groundwater Measurement Information for

Monitoring Wells Located at the Rust Garage Facility . . . . . . . . . . C C-10 


\section{LIST OF ACRONYMS}

$\begin{array}{ll}\text { BCV } & \text { Bear Creek Valley } \\ \text { BGS } & \text { below ground surface } \\ \text { BTEX } & \text { benzene, toluene, ethylbenzene, and xylene } \\ \text { BTX } & \text { benzene, toluene, and xylenes } \\ \text { CAP } & \text { Corrective Action Plan } \\ \text { CERCLA } & \text { Comprehensive Environmental Response, Compensation, and Liability Act } \\ \text { CHI } & \text { Carcinogenic Hazard Index } \\ \text { DOE } & \text { U.S. Department of Energy } \\ \text { EAG } & \text { Environmental Assessment Guidelines } \\ \text { East Fork Regime } & \text { Upper East Fork Poplar Creek Hydrogeologic Regime } \\ \text { EPA } & \text { U.S. Environmental Protection Agency } \\ \text { LEFPC } & \text { Lower East Fork Poplar Creek } \\ \text { MSL } & \text { mean sea level } \\ \text { MTBE } & \text { methyl tertiary butyl ether } \\ \text { ORR } & \text { Oak Ridge Reservation } \\ \text { SHI } & \text { Systemic Hazard Index } \\ \text { TDEC } & \text { Tennessee Department of Environment and Conservation } \\ \text { TGD } & \text { technical guidance document } \\ \text { TPH } & \text { total petroleum hydrocarbons } \\ \text { UEFPC } & \text { Upper East Fork Poplar Creek } \\ \text { UST } & \text { underground storage tank }\end{array}$


I certify under penalty of law, including but not limited to penalties for perjury, that the information contained in this report and on any attachments, is true, accurate and complete to the best of my knowledge, information, and belief. I am aware that there are significant penalties for submitting false information, including the possibility of fine and imprisonment for intentional violations.

\section{See Attached Certification}

Owner/Operator (Print)

Christopher D. Potter Professional Geologist (Print)

\section{Signature}

Date

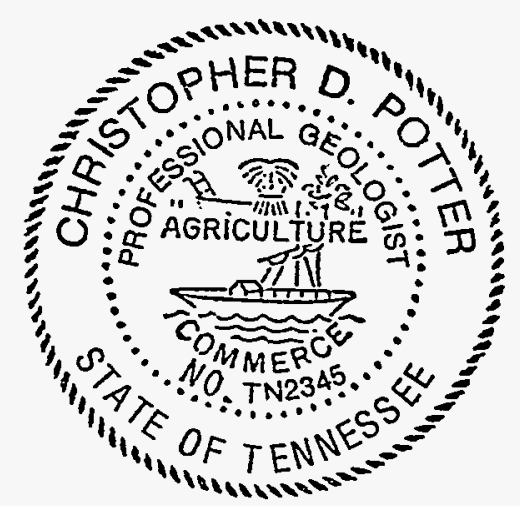

(P.G. Stamp/Seal)

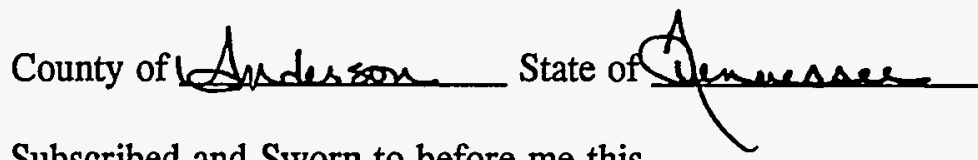

Subscribed and Sworn to before me this

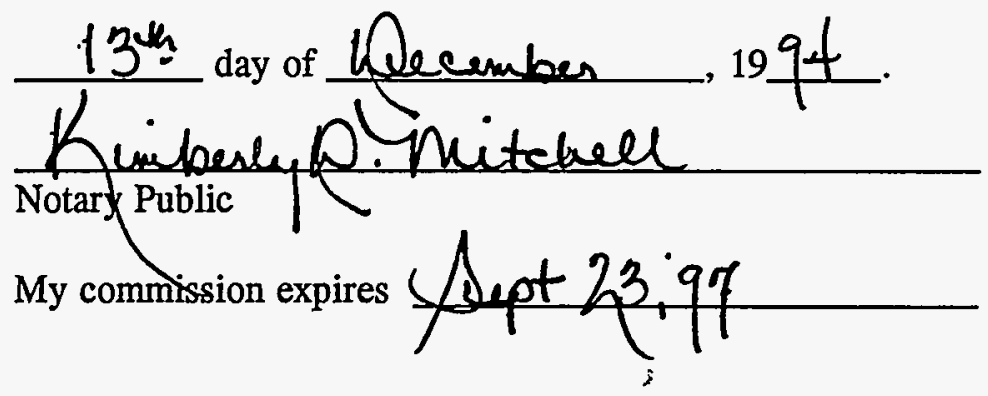

(Notary Seal) 


\section{SIGNATURE PAGE (Page 2 of 2)}

I certify under penalty of law, including but not limited to penalties for perjury, that the information contained in this report and on any attachments, is true, accurate and complete to the best of my knowledge, information, and belief. I am aware that there are significant penalties for submitting false information, including the possibility of fine and imprisonment for intentional violations.

$\frac{\text { WILLIAM N. ROBINSON }}{\text { Professional Engineer (Print) }} \quad \frac{\text { Whlwin N.PLin//101025 }}{\text { Signature TN License/Reg. \# }} \frac{12 / 13 / 94}{\text { Date }}$

If a Professional Engineer signs this report, please indicate the area of expertise.

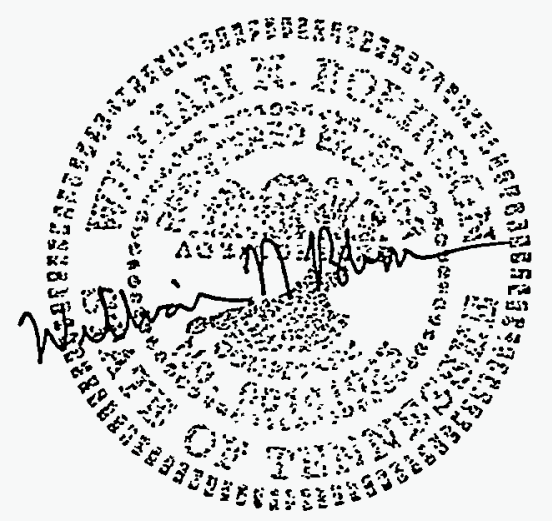

(P.E. Stamp/Seal)

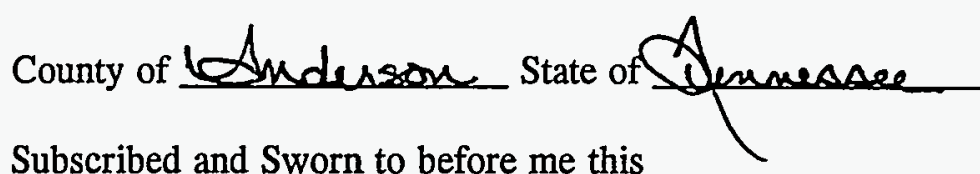

Subscribed and Sworn to before me this

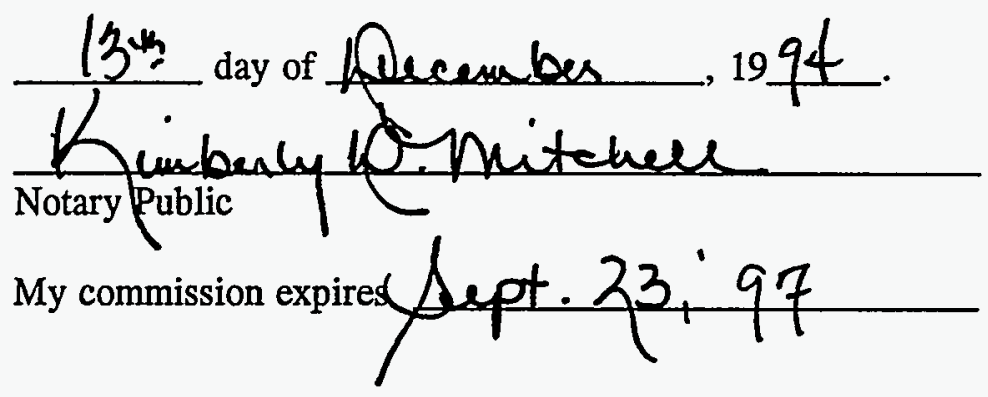

(Notary Seal) 


\section{CERTIFICATION STATEMENT FOR THE SITE-SPECIFIC STANDARD REQUEST \\ FOR UNDERGROUND STORAGE TANKS 1219-U, 1222-U, 2082-U, AND \\ 2068-U AT THE RUST GARAGE FACILITY BUILDINGS 9754-1 AND 9720-15}

I certify that this document and all enclosures were prepared under my direction or supervision in accordance with a system designed to ensure that qualified personnel properly gather and evaluate the information submitted. Based on my inquiry of the person or persons directly responsible for gathering the information, the information submitted is, to the best of my knowledge and belief, true, accurate, and complete.

\section{U.S. Department of Energy}

Owner and Operator

By:
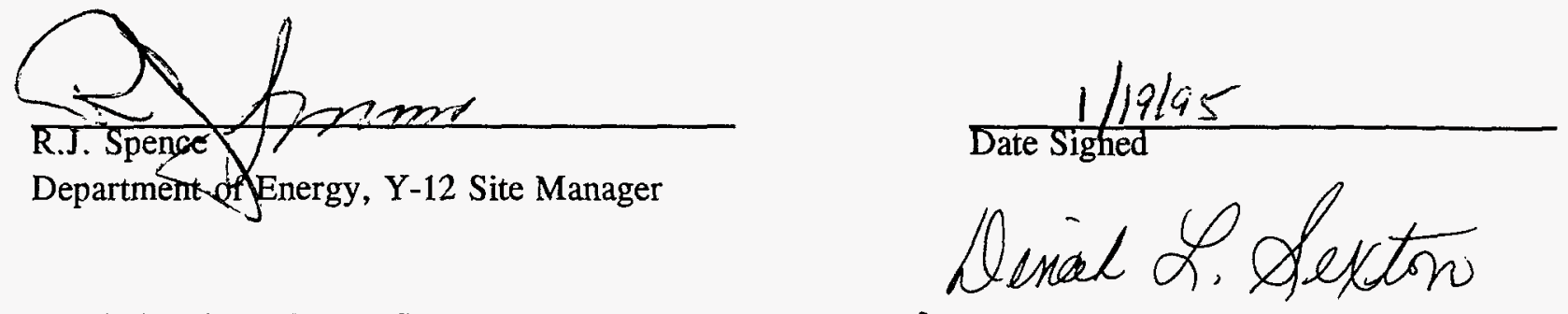

Martin Marietta Energy Systems, Inc.

Co-Operator

My. commission expires Oct. $4,19 \overline{98}$

By:

T.R. Butz

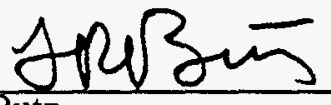

Martin Marietta Energy Systems, Inc.

Y-12 Plant Manager

NOTART

(Stamp/Sejl)

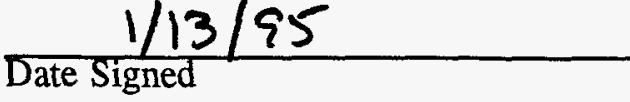

Note: Both signatures have been notarized per requirements.

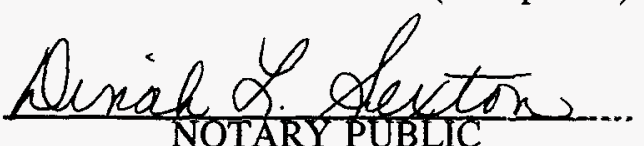

My Commission Expires:

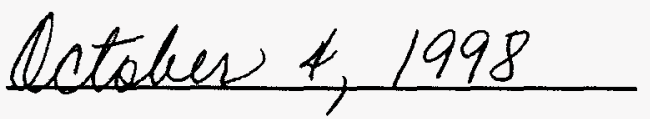




\section{A. EXECUTIVE SUMMARY}

Provide an Executive Summary describing the findings of the project to date. Include conclusions and interpretation of data derived from implementing the environmental assessment and/or corrective action activities. The summary shall include the proposed site-specific cleanup levels.

This document represents a Site-specific Standard Request for underground storage tanks (USTs) 1219-U, 1222-U and 2082-U previously located at former Building 9754-1, and tank 2068-U previously located at Building 9720-15, Oak Ridge Y-12 Plant, Oak Ridge, Tennessee. For the purposes of this Site-specific Standard Request, the tank site comprising Buildings 9754-1 and 9720-15 will be regarded as a single UST site as was the case for previous documentation submitted to the Tennessee Department of Environment and Conservation (TDEC) for this site. This site is commonly referred to as the "Rust Garage Facility" and will be so referenced in this document. This document has been prepared in accordance with TDEC Technical Guidance Document - 008, Procedure to Obtain a Site-specific Standard for a Petroleum Underground Storage Tank Site (January 1994).

The Rust Garage Facility is located at the western end of the Oak Ridge Y-12 Plant (Figure A.1-all figures found at end of respective section). The facility site is generally defined as the area surrounding the current location of Buildings $9720-15$ and 9831 , and the former location of Building 9754-1. The site was previously the location of four active gasoline and diesel USTs (Figure A.2). Three of the USTs were located at Building 9754-1 in a single tank bay; these included a steel 12,000-gallon diesel tank (tank 1219-U), a steel 12,000-gallon gasoline tank (tank 1222-U), and a steel 8,000-gallon gasoline tank (tank 2082-U). The fourth UST was a steel 1,000-gallon gasoline tank (tank 2068-U) previously located along the south side of Building 9720-15. A pressurized underground gasoline transfer pipeline that extended from the two gasoline storage tanks at Building 9754-1 to the single gasoline storage tank at the south side of Building 9720-15 was also previously located at the facility. Above ground product dispenser pumps were also previously located adjacent to both facility tank bays. Installation dates for the underground tanks and transfer lines located at the Rust Garage Facility are as follows: tank 1219-U, pre-1960; tanks 1222-U and 2068-U and the transfer pipeline, 1968; and tank 2082-U, 1982.

During 1980, underground gasoline tank 2068-U located next to building 9720-15 was removed from service because of gasoline leakage from the tank and infiltration of water into the tank. Originally, the tank was abandoned in place, but was later excavated and removed in February 1990. During September 1987, tightness testing conducted on diesel tank 1219-U indicated that leakage from the tank was occurring. During this test approximately 85 gallons of diesel fuel were released. Based on the assumption that the leakage from the tank had occurred in the upper portions of the tank or the associated piping, the tank was used for restricted diesel storage until March 1988, at which time the tank was emptied and removed from service. The tank was excavated and removed in December 1989. Leakage from the gasoline transfer pipeline was suspected in January 1988 after oily water was observed seeping from cracks in pavement downgradient of the line. During testing of the pipeline in February 1988, the transfer pipeline was found to be leaking. Subsequently, the line was capped and removed from service. Excavation and removal of the transfer pipeline occurred in February 1990. During May 1988, tightness testing of gasoline tanks 1222-U and 2082-U at Building 9754-1 was conducted. Tank 1222-U passed the test, but tank 2082-U failed primary and secondary tests. Subsequently all product was removed from tank 2082-U and all fuel dispensing operations were discontinued at Building 9754-1. These tanks were also removed in December 1989. 
Detailed information concerning the history of free product removal and site investigation activities conducted between 1980 and 1990 is presented in the Corrective Action Plan (CAP) for the Rust Garage Facility (Y/SUB-92-99928C/2). The CAP for the facility was submitted to TDEC in May 1992. An addendum to the CAP was issued in February 1994. Remediation actions for both soil and groundwater were defined in the CAP and addendum. Prior to the implementation of corrective action, TDEC issued the second edition of the Underground Storage Tank Reference Handbook (January 1994). The revised handbook included a revision of technical guidance document (TGD)-008 that, in conjunction with other regulatory changes, indicated that site status monitoring might be the most appropriate disposition for the site.

Based on the determination that groundwater at the Rust Garage Facility is classified as a nondrinking water source, the applicable TDEC Closure Action Levels for groundwater remediation at the site would be $0.070 \mathrm{ppm}$ benzene and $1.0 \mathrm{ppm}$ total petroleum hydrocarbons (TPH). Analytical results for groundwater samples collected during site investigations indicate that a single area of groundwater contamination, exceeding applicable action levels, extends south from the former Building 9720-15 tank bay, approximately $80 \mathrm{ft}$, to a point just north of monitoring well GW-631 (see Figure B.7). Based on the rapid thinning of contamination away from the suspected source, the thickness of impacted groundwater is interpreted to be relatively small, extending only several feet below the water table. The location of this contamination area suggests that leakage of product from gasoline tank 2068-U and/or from the underground gasoline transfer pipeline are probable sources for the observed contamination.

Based on the nondrinking water source classification for groundwater at the Rust Garage Facility and analysis of slug testing data for several monitoring wells at the site that indicate that soil permeabilities range between $10^{-3}$ and $10^{-5} \mathrm{~cm} / \mathrm{sec}$, the applicable TDEC Closure Action Levels for soil remediation at the site would be $250 \mathrm{ppm}$ total benzene, toluene, and xylenes (BTX) and $500 \mathrm{ppm}$ TPH. Analytical results for soil samples collected during several site investigations at the site suggest that no soil contamination in excess of $250 \mathrm{ppm}$ total BTX is present; however, several soil samples were found to exhibit TPH values exceeding the applicable action level. Soil TPH contamination at the facility appears to be located within two separate areas, a smaller area located in the immediate vicinity of the former Building 9754-1 tank bay and a larger area extending south from the former Building 9720-15 tank bay (see Figure B.1). The vertical extent of soil contamination at the site is at variable depth and transfer line between the ground surface and the local potentiometric surface.

The site-specific standards being requested for approval by TDEC for the Rust Garage Facility are presented in Table A-1 (all tables found at end of respective section). These site-specific standards are justified based on conclusions derived from the exposure assessment that indicates there is no current or foreseeable future human health risk associated with petroleum contaminants at the site, and that the current and future ecological risks associated with the contaminants would be generally limited to terrestrial species living within the subsurface environment at the site (i.e., earthworms) and plant life that has root systems extending into contaminated media. This risk is further limited since most of the impacted area at the site is covered by asphalt or concrete. These conclusions are supported by the observation that the vertical and horizontal extent of soil and groundwater contamination are limited to the immediate area of the Rust Garage Facility that is located within the access restricted Y-12 Plant.

The current land use associated with the Y-12 Plant is light industrial. The operational period of the plant is projected to be at least 30 years, with an additional passive institutional control period of 100 years. Thus, potential future residential exposures are not expected to occur for at least 30 years. Based on the degradation coefficient for benzene (the only carcinogenic petroleum constituent detected 
in soils or groundwater at the Rust Garage Facility), it is expected that the benzene and other contaminant compounds at the site will likely be reduced prior to expiration of the 30-year plant operational period, and well within the timeframe for assumed institutional controls. The reduction of all contaminant levels at the Rust Garage Facility will undoubtedly be aided by various natural mechanisms including volatilization, biodegradation, and aquifer flushing. Based on the removal of the original source, the limited area of petroleum contamination present and the absence of exposure, a site-specific standard is now being requested for the Rust Garage Facility. 


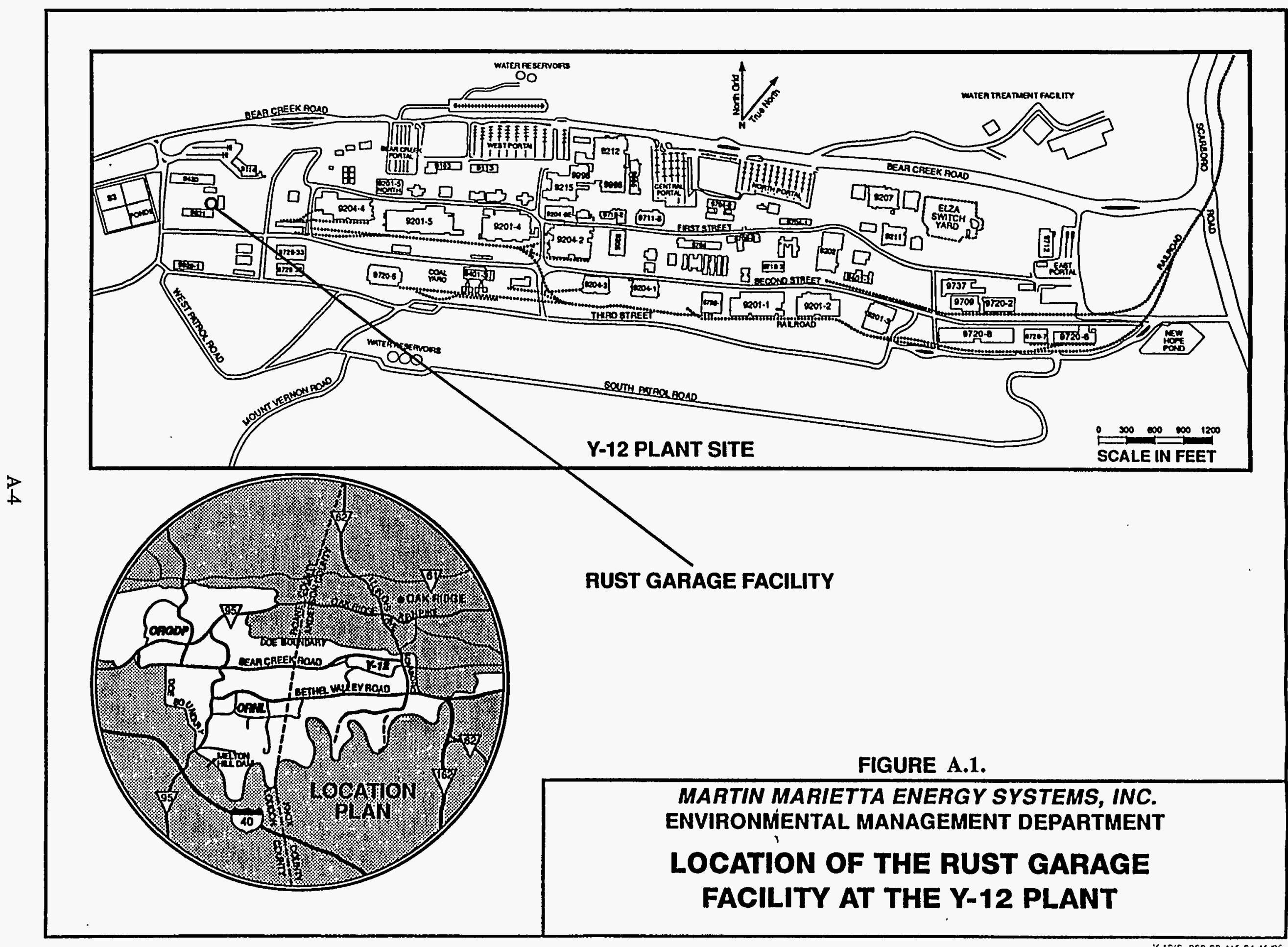




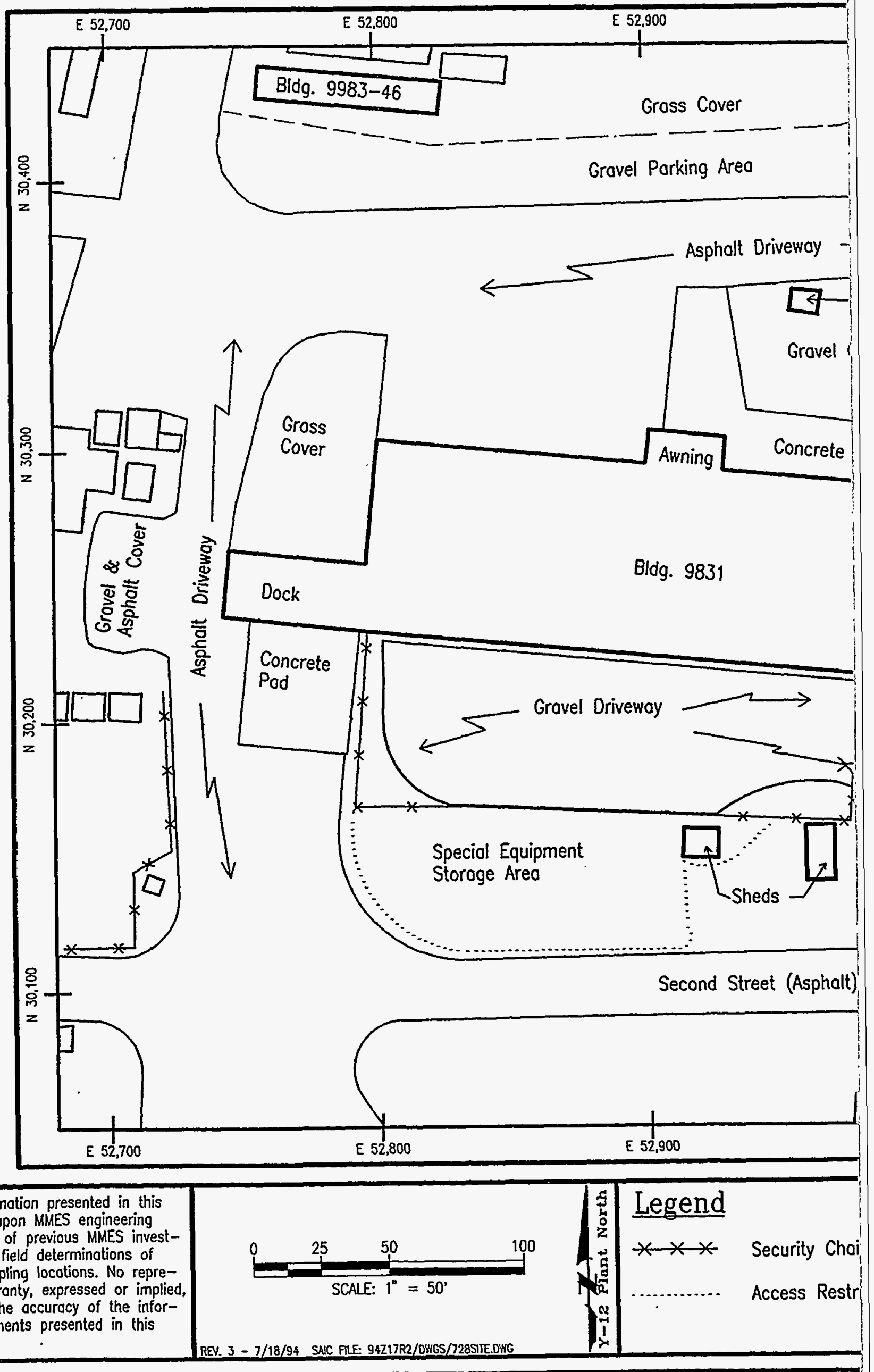

All location information presented in this figure is bosed upon MMES engineering drawings, results of previous MMES investigations, and/or field determinations of feoture and sompling locotions. No representation or worranty, expressed or implied is made as to the accuracy of the information or stotements presented in this figure.

Bidg. 9983-46

Grovel Porking Area

Bldg. 9831

능

Special Equipment Storage Area

Second Street (Asphalt) 


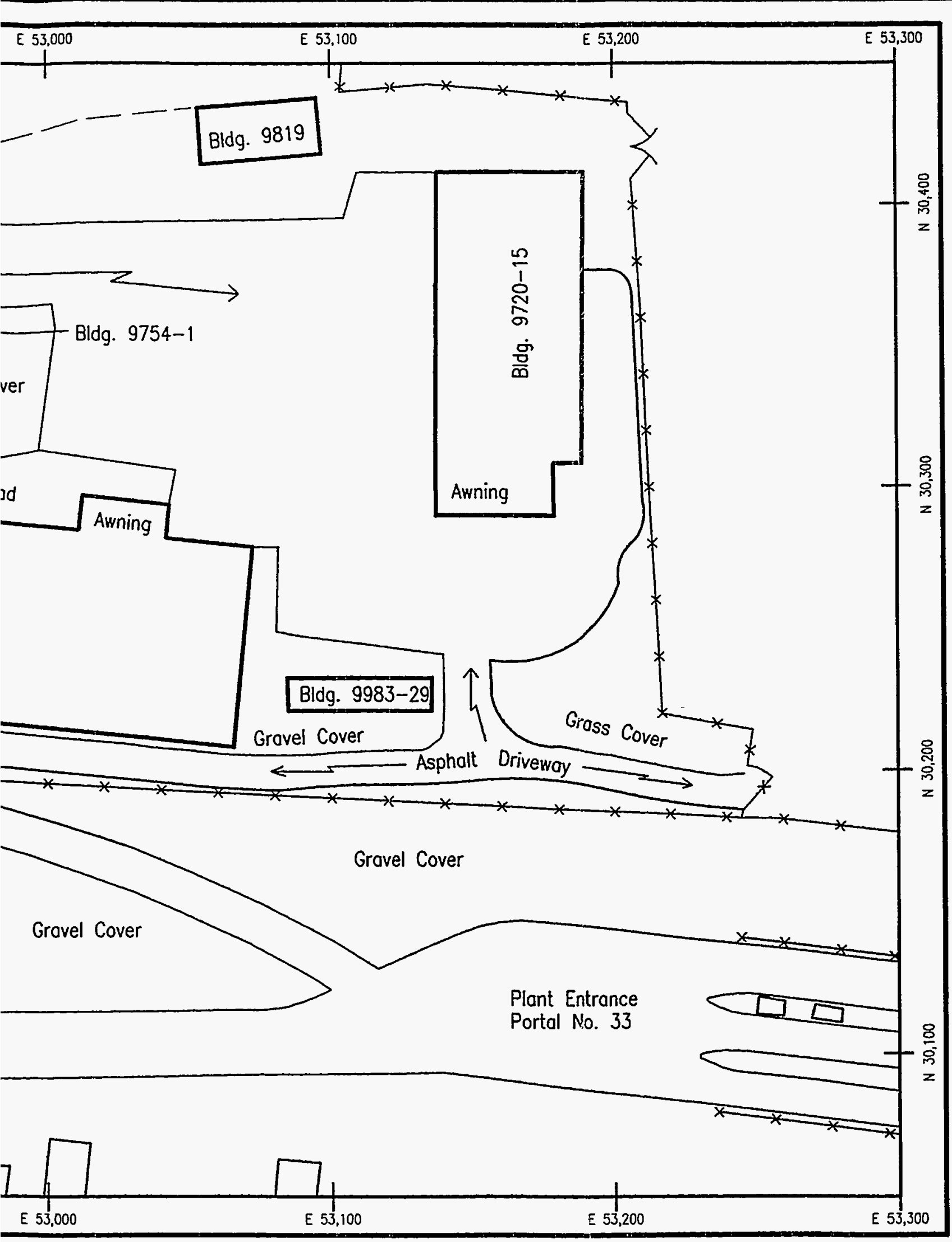

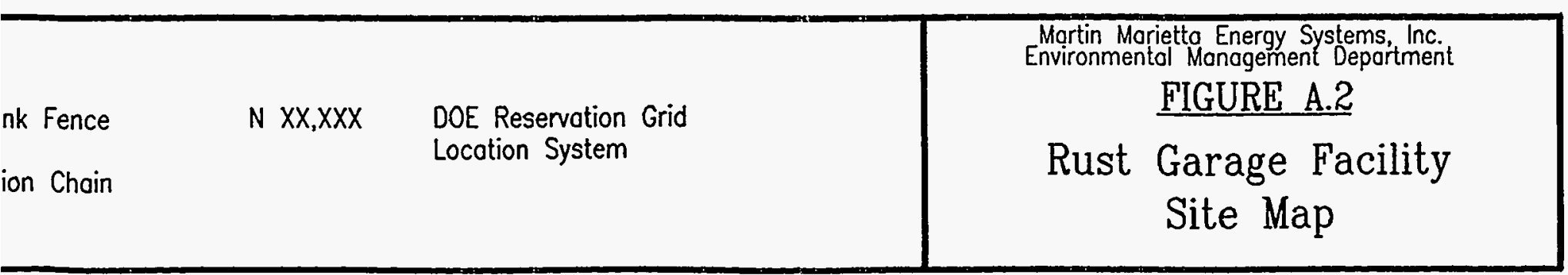


Table A.1. Proposed Site-Specific Cleanup Levels for the Rust Garage Facility

\begin{tabular}{clrrr}
\hline $\begin{array}{c}\text { Exposure } \\
\text { Media }\end{array}$ & $\begin{array}{c}\text { Constituent } \\
\text { Released }\end{array}$ & $\begin{array}{c}\text { Requested } \\
\text { Concentration }\end{array}$ & Criteria Value & $\begin{array}{c}\text { Applicable Closure } \\
\text { Action Level }\end{array}$ \\
\hline Groundwater & Benzene & $19.0 \mathrm{ppm}$ & $0.005 \mathrm{ppm}$ & $0.070 \mathrm{ppm}$ \\
& Toluene & $46.0 \mathrm{ppm}$ & $10.0 \mathrm{ppm}$ & Not Applicable \\
& Ethyl-Benzene & $7.0 \mathrm{ppm}$ & $4.0 \mathrm{ppm}$ & Not Applicable \\
& Xylenes & $70.0 \mathrm{ppm}$ & $70.0 \mathrm{ppm}$ & Not Applicable \\
& MTBE & None & $0.7 \mathrm{ppm}$ & Not Applicable \\
& & & & \\
Soil & & & & \\
& Benzene & $1.10 \mathrm{ppm}$ & $240 \mathrm{ppm}$ & $250.0 \mathrm{ppm}$ total BTX \\
& Toluene & $11.06 \mathrm{ppm}$ & $20000 \mathrm{ppm}$ & $250.0 \mathrm{ppm}$ total BTX \\
& Ethyl-benzene & $3.40 \mathrm{ppm}$ & $8000 \mathrm{ppm}$ & $250.0 \mathrm{ppm}$ total BTX \\
& Xylenes & $56.0 \mathrm{ppm}$ & $200000 \mathrm{ppm}$ & $250.0 \mathrm{ppm}$ total BTX \\
& TPH & $3800.0 \mathrm{ppm}$ & $11287 \mathrm{ppm}$ & $500.0 \mathrm{ppm}$ \\
\hline
\end{tabular}




\section{B. Provide the Physical and Chemical Characteristics of Petroleum; Including Its Toxicity, Persistence, and Potential for Migration}

\section{B.1 Physical Characteristics}

\section{B.1.a The source(s) of contamination and amount released}

The USTs and the transfer pipeline that were the primary sources of subsurface petroleum contamination at the Rust Garage Facility have all been excavated and removed from the site. Therefore, the only current contamination source that exists at the site is residual contaminated subsurface soil.

Known sources of contamination at the Rust Garage Facility included past releases from tanks 2068-U, 1219-U, and 2082-U, and releases from the underground transfer pipeline which extended between the former tank at Building 9720-15 and the former tanks at Building 9754-1. The first discovery of a petroleum product release at the Rust Garage Facility occurred at gasoline tank 2068-U, located next to Building 9720-15. In 1980, this tank was removed from service because of gasoline leakage from the tank and infiltration of groundwater into the tank. The tank was abandoned in place by removing the fuel contents and filling the tank with clean sand. The tank was excavated and removed in February, 1990, and the soil from the excavation was returned to the former tank pit. Inspection of the tank after removal revealed numerous corrosion holes. No records exist concerning the quantities of gasoline which may have been released from the tank.

Infiltration of groundwater into diesel tank 1219-U and gasoline tank 2082-U was discovered in 1982. The diesel tank was tightness tested in 1987, and the gasoline tank was tested in 1988. Both tanks failed testing and approximately 85 gallons of fuel were released during the diesel tank test. Although no corrosion holes were found in either of the tanks upon their removal in 1989, leakage of product from small holes located in the fill tube necks of these tanks probably occurred during the operational life of the units.

In 1988, a release from the underground transfer pipeline was suspected after oily water was observed seeping from an isolated area of cracked pavement located south of the line. In February 1988, the transfer pipeline failed a tightness test conducted with soapy water and was subsequently capped and removed from service. The contaminated water seep was observed to occur only following rainfall. The seep was attributed to an 18-inch stormwater drainage line, extending across the transfer line trench, that had been severed during excavation of the trench but not plugged at an upgradient inlet. It was concluded that water entering the trench from the north section of the severed drain line flushed product released from the transfer line south to the area of the water seep. The transfer line was excavated and removed in 1990.

Other than the approximately 85 gallons of fuel released during testing of diesel tank 1219-U, the amount of petroleum product released from tanks 2068-U, 1219-U, and 2082-U, and from the underground transfer pipeline is not documented. However, during a preliminary assessment of the site conducted in April 1988, free product was observed and measured in one of three installed piezometers (GW-507, GW-508, GW-509). Free product in well GW-508 was found to accumulate and increase in measured thickness from approximately $1.5 \mathrm{ft}$ on April 20, 1988 to approximately $3.5 \mathrm{ft}$ by April 30 , 1988. Between October, 1988 and July 20, 1990, GW-508 was pumped until free product was reduced to below recoverable limits, at which point approximately 150 gallons of free product had been removed. 


\section{B.1.b The background level of each constituent in both the soil and groundwater of the area if naturally-occurring petroleum is suspected to exist upgradient of the contaminant plume(s)}

No known or suspected naturally-occurring sources of petroleum contamination exist at or upgradient of the Rust Garage Facility.

\section{B.1.c The media through which the release is spreading or is likely to spread, the direction, and the rate}

Analytical data from various investigations conducted at the Rust Garage Facility have shown that contamination has affected both subsurface soils and groundwater. Generated data included the results of chemical analyses for soil and groundwater samples collected in December 1989 during the removal of tanks 1219-U, 1222-U and 2082-U, and in February 1990 during the removal of the underground gasoline transfer pipeline and tank 2068-U at Building 9720-15. Analytical data were also generated for soil samples collected from sampling (SB series) and monitoring well (600 series) boreholes drilled during the Site Investigation in May 1990. Additional analytical data for groundwater was collected as part of the annual Y-12 Plant Groundwater Quality Assessments (1989-1993), and during comprehensive monitoring conducted at the site in April 1994.

Section B.1.d of this report provides descriptions and site maps illustrating the contaminant plumes at the Rust Garage Facility. Based on the geometry and location of the larger of the two soil contamination plumes illustrated in Figure B.1, the apparent direction of contaminant migration in the unsaturated zone is from the north-northwest to the south-southeast. This direction is evidenced by the location of the soil contamination plume, south and extending slightly east of two of the suspected sources (tank 2068-U and the gasoline transfer line). Additionally, a south-southeast direction of contaminant migration is supported by the surface topography of the site and the direction of surface runoff that is from northwest to southeast. Cross-sections A-A', C-C' and D-D' (Figures B.2, B.4, and B.5) depicting the vertical extent of TPH contamination greater than $500 \mathrm{ppm}$ indicate that contamination has migrated to contact the water table south of Building 9720-15. This probably indicates a downward component of contaminant migration.

Based on mapping of the potentiometric groundwater surface at the Rust Garage Facility, using measurements obtained during April and May between 1988 and 1990 and additional measurements obtained in November 1993 and April 1994 (see Section C.1.d), the direction of groundwater flow was determined to be generally from the north-northwest to the south-southeast across the facility. This flow direction is in part influenced by the joint structures and fractures of the underlying bedrock, and generally coincides with the surface topographic slope at the facility. Based on slug testing analyses conducted in several of the site monitoring wells, the hydraulic gradient was determined to be $0.07 \mathrm{~cm} / \mathrm{cm}$, with an average linear velocity equal to $14.5 \mathrm{ft} /$ year. (hydraulic gradient and average linear velocities recalculated from data in the Corrective Action Plan for the Rust Garage Facility, Appendix G, Y/SUB/92-99928C/1).

\section{B.1.d Site maps showing the contaminant plume(s) defined to the applicable cleanup levels as listed in Appendices 3 and 4 of Rule 1200-1-15}

A majority of the Rust Garage Facility site is covered by asphalt or concrete which is underlain by unconsolidated materials consisting of manmade fill, alluvial fill, residual soil, and weathered bedrock. These materials range in total thickness from approximately 8 to $16 \mathrm{ft}$ across the site. Manmade fill 
forms a nearly continuous cover at the site. Alluvial fill and residual soil underlie the manmade fill, and a poorly defined boundary separates the residual soil from the underlying weathered bedrock/saprolite. The Nolichucky Shale comprises the competent bedrock beneath the Rust Garage Facility. This formation is predominantly composed of shale; however, zones of shale interbedded with limestones and siltstones are common.

At the site, manmade fill consists primarily of a surficial layer of limestone gravel or a mixed clayey gravel, ranging 0.5 to $5.0 \mathrm{ft}$ in thickness. This is underlain by an excavated and transported yellow brown to green brown clay-rich fill with rock fragments. The residual soil beneath the manmade fill ranges from 0 to $13 \mathrm{ft}$ in thickness and consists of yellow to green brown and yellow green, locally carbonaceous, shaley clay with abundant shale fragments. Two alluvial deposits were identified during drilling. These consist of clayey silt with rounded fragments of weathered limestone, sandstone, and shale, and may be geologically recent channel deposits. These deposits appear to be of limited extent and cross-cut earlier soils. Saprolite or weathered bedrock underlies the residual soil and alluvial deposits, and has poorly defined gradational contacts with adjacent units. The saprolite consists of clayey shale fragments that preserve the original rock fabric, including numerous iron-stained fractures.

Analytical data to support the delineation of soil contamination at the Rust Garage Facility were derived from several investigations noted in Section B.1.c of this document. A summary of all analytical data generated for soils is presented Table B.1. Figure B.1 shows a composite of the locations where boreholes were drilled during previous investigations to characterize soil contamination at the site.

Delineation of the horizontal extent of petroleum contamination within soils at the Rust Garage Facility is also presented in Figure B.1. This delineation is based on field observations and soil sampling results generated from the previous investigations conducted at the facility. Two types of delineations were developed for the facility, one defining the extent of contamination greater than the most stringent TDEC Closure Action Levels for soils (100 ppm TPH and $10 \mathrm{ppm}$ total BTX), and the other defining the extent of contamination greater than the applicable Closure Action Levels for soils at the Rust Garage Facility (500 ppm TPH and $250 \mathrm{ppm}$ total BTX). However, none of the soils at the facility were found to exceed the applicable level of $250 \mathrm{ppm}$ for total BTX.

Soil contamination at the facility appears to be located within two separate areas, a smaller area located in the immediate vicinity of the former Building 9720-15 tank bay and a larger area extending south from the former Building 9720-15 tank bay and transfer line. The delineation of both the most stringent and applicable contamination levels within the two noted contamination areas generally encompass the same approximate areal extent. The only major deviation of the two types of delineation occurs at the north end of the larger contamination area where the limit of the most stringent level soils extends approximately $\mathbf{5 0}$ additional feet northwest of the limit of the applicable level soils.

Delineation of the vertical extent of contamination in excess of $500 \mathrm{ppm}$ TPH within soils at the Rust Garage Facility is based on five cross-section lines (lines $A-A^{\prime}$ through $E-E^{\prime}$ ) established across critical sections of both contamination areas at the facility (Figure B.1). Subsurface conditions within the smaller contamination are projected onto line $\mathrm{A}-\mathrm{A}^{\prime}$, which is depicted in Figure B.2. This crosssection line shows the presence of an apparently isolated contamination lens ranging up to $0.5 \mathrm{ft}$ in thickness and at a shallow depth located along the southern margin of the former Building 9754-1 tank bay. A similar lens at the same depth is located along the northern margin of this tank bay. 
Subsurface conditions within the larger contamination area are projected onto lines $A-A^{\prime}$ through E-E' that are depicted in Figures B.2 through B.6. Cross-section lines $A-A^{\prime}, D-D^{\prime}$, and $E-E^{\prime}$ show the presence of a single soil contamination zone exhibiting variable thickness, which is generally located on top of the local groundwater table in this area of the facility. This contamination zone begins as a relatively symmetrical concave lens approximately $3 \mathrm{ft}$ in maximum thickness at the north end of the zone, expands to a west sloping wedge varying in thickness from approximately $4.5 \mathrm{ft}$ at the east end to approximately $0.5 \mathrm{ft}$ at the west end, and decreases to a relatively flat lens approximately $0.5 \mathrm{ft}$ in thickness at the south end of the zone. Cross-section line C-C' shows that contaminated soil along the north-south axis of the zone maintains a relatively uniform thickness of approximately $3 \mathrm{ft}$ in the north and central parts of the zone, and rapidly decreases to a thickness of approximately $0.5 \mathrm{ft}$ in the south part of the zone.

A comprehensive description of the groundwater system at the Rust Garage Facility is presented in Section C. 1 of this document. Analytical data to support the delineation of groundwater contamination at the site have been derived from several of the investigations noted in Section B.1.c of this document. A summary of all analytical data generated for groundwater is presented in Table B.2. Figure B.7 shows a composite of the locations where monitoring wells were installed during previous investigations to characterize groundwater contamination at the site.

Delineation of the horizontal and vertical extent of petroleum contamination within groundwater at the Rust Garage facility was accomplished using analytical results for both TPH and benzene from the last round of sampling conducted at the site. The last round of sampling was conducted during comprehensive monitoring, which occurred on April 5, 1994. As directed by TDEC, monitoring wells GW-508, GW-631, GW-632, and GW-634 were sampled during this event. Based on this data, two types of delineations were developed, one defining the extent of contamination greater than the most stringent TDEC Closure Action Levels for groundwater $(0.005 \mathrm{ppm}$ benzene and $0.100 \mathrm{ppm}$ TPH) and the other defining the extent of contamination greater than the applicable Closure Action Levels for groundwater at the Rust Garage Facility (0.070 ppm benzene and $1.0 \mathrm{ppm}$ TPH).

Groundwater contamination at the facility appears to be located within a single area extending south from the former Building 9720-15 tank bay (Figure B.7). The delineation of both the most stringent and applicable contamination levels within the noted contamination area generally encompasses the same approximate areal extent.

Delineation of the vertical extent of benzene contamination in excess of $0.070 \mathrm{ppm}$ and TPH $>1.0 \mathrm{ppm}$ within groundwater at the Rust Garage Facility is based on two cross-section lines (lines C-C'

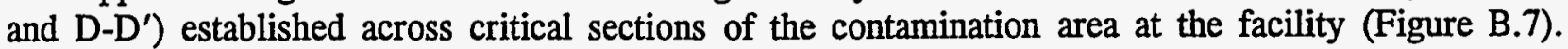
Subsurface conditions within the contamination area projected onto these lines are depicted in Figures B.8 and B.9. These cross-section lines show the presence of a groundwater contamination lens that appears to exhibit a maximum thickness of several feet below the local water table.

Petroleum product contamination originating from the tank 2068-U bay and/or the transfer pipeline trench would be expected to migrate south under the influence of the local groundwater flow. This concept is supported by the delineation of the groundwater contamination area at the facility. The elongate east-west shape of the contamination area may, in part, be attributed to local bedrock bedding planes and joints that influence the movement of groundwater within overlying unconsolidated material zones. The apparent limited depth of groundwater contamination below the local water table at the facility is believed to result from the strong upward flow component of the local hydrological regime. 
This component of flow would restrict the downward migration of contaminants originating from a surface or near surface source.

\section{B.1.e The results of a Synthetic Precipitation Leach Test (SW-846, Method 1312, July 1992) if BTX soil contamination is present above applicable cleanup levels (Note: The soil sample shall be collected in the area of highest known contamination and analyzed for the groundwater constituents in Worksheets 1 and 2)}

No BTX soil contamination above the applicable cleanup levels has been identified at the Rust Garage Facility. For this reason, a synthetic precipitation leach test has not been performed.

\section{B.2 Chemical Characteristics}

B.2.a A comparison of the constituents by completing Worksheets 1 and 2 (Note: If the released and requested constituent concentrations are the same, only complete Worksheet 1 . If the released and requested constituent concentrations are different, give the rationale for selecting the requested concentrations.)

The petroleum constituents released at the Rust Garage Facility were derived from both gasoline and diesel product. The petroleum contaminants present at the site include benzene, toluene, ethylbenzene, xylenes (BTEX), and TPH. These contaminants are present in both soil and groundwater. However, none of the soils at the facility were found to exceed the applicable level of $250 \mathrm{ppm}$ for total BTX. A comparison of the constituents released at the facility is presented in Worksheet 1 (Attachment A). As directed and approved by TDEC-U.S. Department of Energy (DOE) Oversight Division, the maximum concentrations from the most recent sampling event (comprehensive monitoring) are presented for groundwater.

The nature of releases at the Rust Garage Facility produced no observable affects to adjacent surface water bodies. All surface water exiting at the Y-12 Facility is monitored through permitted outfalls and no sheens or volatile organic compounds attributable to the Rust Garage Facility have been reported at these compliance points. Because surface water bodies have not been affected by releases at the Rust Garage Facility, sections of Worksheets 1 and 2 that pertain to surface water have been marked "NA" or not applicable. Likewise, no adverse effects to ambient air quality have been documented at the Rust Garage Facility, and, therefore, the section of Worksheets 1 and 2 that pertains to air has been marked "NA."

Contaminants exhibiting concentrations in groundwater that exceed the TDEC Criteria Values (Worksheet 1) are benzene and toluene. Methyl tertiary butyl ether (MTBE) was not an analyte of concern at the time the investigations were conducted at the Rust Garage Facility. Therefore, this constituent was not considered as part of the Systemic Hazard Index (SHI). The Carcinogenic Hazard Index (CHI) for groundwater at the site is calculated to be 1840 , and the summed SHI is 3.364. Both of the index results are in excess of a guideline value of 1.0. Analyses of TPH in groundwater also indicate that this contaminant is of potential concern because it has been detected in excess of the applicable TDEC Closure Action Level.

The requested constituent concentrations are presented in Table A-1 and Worksheet 2 (Attachment A). The requested concentrations for soil are the maximum concentrations observed in soil, and therefore, are the same as the values presented in Worksheet 1 . All values are significantly below the 
criteria value. For soils $12 \mathrm{ft}$ or less, the $\mathrm{CHI}$ is calculated to be $4.58 \times 10^{-2}$, and the summed SHI is 0.3380 . For soils greater than $12 \mathrm{ft}$, the $\mathrm{CHI}$ is calculated to be $4.0 \times 10^{-4}$, and the SHI is 0.0151 .

The requested constituent concentrations for groundwater are proposed based on the observations of analytical data for the site collected since 1989. The requested concentrations for benzene, toluene, and ethylbenzene are $19.0 \mathrm{ppm}, 46.0 \mathrm{ppm}$, and $7.0 \mathrm{ppm}$ (respectively). Each of these requested values represent concentrations that are slightly greater than the maximum (singular) high values for each constituent observed during previous sampling. The requested concentrations for benzene, toluene, and ethylbenzene have not been met or exceeded at the site, but are selected to allow for seasonal fluctuations and periodic contaminant flushing that may occur during monitoring. The U.S. Environmental Protection Agency (EPA) criteria of $70 \mathrm{ppm}$ is requested for xylenes.

Several points that mitigate the impact of the elevated hazard index scores for groundwater at the site include the following: (1) groundwater movement at the site is very slow, and contaminants within the groundwater will not reach potential receptors for an extended period of time; (2) monitoring and control of exit pathway endpoints will occur during the operational period of the Y-12 Plant which is projected to be at least 30 years; (3) the constituents of concern are subject to natural degradation, producing minimal to no risk by the time the constituents reach potential receptors; and (4) the approved nondrinking water quality standard for the Rust Garage Facility suggests that the TDEC Criteria Values are overly stringent for the water quality and water use at the site.

\section{B.2.b The mobility of each constituent (i.e., solubility in water, ability to move by vapors, absorption by soil, etc.)}

\section{B.2.b.i Gasoline - Benzene, Ethylbenzene, Toluene, Xylene, Methyl Tertiary Butyl Ether, Di-Isopropyl Ether, TPH - Gasoline Range Organics}

\section{B.2.b.ii Diesel, Kerosene, Waste Oil, etc. - TPH - Diesel Range Organics/418.1}

Table B.3 presents some commonly used quantitative parameters to describe the mobility, persistence, and toxicity of both gasoline and diesel petroleum constituents. Individual sets of parameters for BTEX are presented. However, no single set of these parameters is available for TPH. Therefore, the chemical benzo(a)pyrene, which is a fairly ubiquitous by-product chemical of combustion and asphalt use, is used as a point of reference for TPH.

Benzo(a)pyrene is relatively insoluble, and, thus, the quantitative values describing mobility should be different from the relatively soluble BTEX constituents. As indicated by the parameters "solubility" and "octanol-water partition coefficient" in Table B.3, the BTEX compounds are relatively soluble and have a tendency to partition from solid to liquid. This tendency is also reflected in the other quantitative parameters. The BTEX compounds also readily partition into the gaseous phase, as shown by the relatively high Henry's Law Constant values.

As indicated by the toxicity information, the BTEX compounds are generally not as toxic or carcinogenic as the chemical compounds that comprise TPH. The primary reason for this is that compounds that are less soluble are lipophilic and tend to accumulate in the body, whereas soluble compounds are more easily cleared from the body. However, while not as potent as other known carcinogens, benzene is one of the few chemicals that is known to be a human carcinogen. 
The values of the "octanol-water partition coefficient" can be made more site-specific by defining a partition coefficient $\left(\mathrm{K}_{o c}\right)$ between solvents in water and the soil organic carbon. A fraction of the BTEX constituents will partition into the soil organic carbon phase. Application of the $K_{o c}$ requires sitespecific data on total organic carbon in soil.

Natural soils and residuum within Bear Creek Valley are characterized by structures (bedding planes, fractures) inherited from the parent bedrock. These structures tend to focus fluid flow between and around blocks of soil matrix. Contaminants flowing through the soils prior to removal of the source will tend to diffuse into the pores of the matrix blocks. Following removal of the source, contaminants stored in matrix pores will slowly diffuse out into water flow zones. This process of matrix diffusion limits the rate of removal of dissolved contaminants from such sites.

The migration of water and dissolved contaminants from the waste source to the receptor involves flow through both unsaturated (vadose zone) and saturated zones. Flow in these zones is controlled by Darcy's law, which states that the volumetric flow is proportional to the product of the driving force, the material's ability to transmit water, and the cross-sectional area perpendicular to the flow direction. The driving force for the flow in saturated conditions is the hydraulic gradient.

Dispersion (mixing) in groundwater is primarily caused by molecular diffusion, varying pore sizes, varying path lengths, variation in velocity gradients across the pore space, and flow splitting around matrix particles. In groundwater, dilution due to mixing occurs at a much slower rate than in surface water, and the overall magnitude of dispersion is smaller. In addition to dispersion, both attenuation and retardation should be considered in transport modeling.

Attenuation is the loss of contaminants from the plume. While the mass of the contaminant is not changed, a certain percentage of the total contaminant will be removed from the solution by geochemical reactions and will no longer be available for transport. Attenuation is used to model those processes that immobilize contaminants. These mechanisms can include hydrolysis, complexation, oxidation/reduction reactions, acid/base reactions, organic and radioactive decay, and chemical precipitation. The attenuation process can be accounted for by the use of decay constants (biodegradation rates) for the organic compounds.

Retardation consists of reversible reactions that slow the movement of a constituent. Retardation causes the development of a plume that has a long tail of decreasing concentration. The plume will be present for extended time periods following source removal. These adsorption processes have a substantial potential to alter the migration rate of reactive solutes, and for compounds with high partitioning coefficients, may be the dominant influence on the transport process. The partitioning coefficient $\left(K_{d}\right)$ is used to derive a retardation factor $(R f)$. Although the $K_{d} / R f$ formulation of the reaction term of the transport equation has numerous assumptions and uncertainties associated with it, it nevertheless provides a practical means of incorporating the reaction process into transport models. $K_{d}$ values for the organic compounds can be obtained by calculations based on octanol-water partition coefficients (literature values) and fractional organic carbon content (site specific values).

To account for these processes a simple one-dimensional analytical solution technique was applied to groundwater contamination at the Rust Garage Facility. Since TPH is representative of a complex range of organic chemicals and no established literature values are available for modeling its fate and transport in the environment, benzene was selected for modeling. ODAST (Javendel et al. 1984), a onedimensional analytical model was used to predict the fate and transport of benzene, as a conservative 
representation of groundwater contamination (benzene would be the most mobile constituent), from the source areas to the nearest receptor location (Table B.4). The model calculates the normalized concentrations of benzene in a uniform flow field along a homogenous isotropic porous medium, from a source having a constant or varying concentration. ODAST evaluates the basic one-dimensional analytical solute transport equation as a function of seepage velocity, dispersion coefficient, source decay, retardation factor, depletion time, and radioactive decay or biodegradation rate. Where values for specific input parameters were not available for the Rust Garage Facility, conservative literature values were chosen for modeling purposes (Table B.4 provides a typical range for input parameters taken from literature). Simulations were performed for a period of 500 years with a 5-year time step to project the concentrations at a distance of $4,500 \mathrm{ft}$ (shortest distance to a receptor location where groundwater discharges into surface water) downgradient from the source. Attachment B presents the tabulated results of the ODAST model.

Modeling results indicate that the maximum concentration of benzene in groundwater before entering the surface water (using highly conservative values for the input parameters) will range from 0.0 $\mathrm{ppm}$ to $0.092 \mathrm{ppm}$. The groundwater concentration will be significantly diluted (more than an order of magnitude) with surface water as soon as it enters the surface water body (East Fork Poplar Creek). Therefore, the concentration of benzene in surface water due to contribution from the groundwater will be significantly lower than the maximum concentration in groundwater. Simulation results also indicate that with the retardation factor of 4 (which is probably more representative of actual site conditions), benzene will be completely degraded before reaching the receptor location. When the simulation was performed using the average hydraulic conductivity at the site, $(0.283 \mathrm{ft} /$ day $)$ the benzene plume would be expected to reach the receptor location in 50 years and the maximum concentration was projected at $6.4 \mathrm{E}-13 \mathrm{ppm}$. It should be noted that the actual retardation factor and organic decay constant may not closely follow the assumed literature value, particularly over the long term. Also, the source depletion time of 100 years may be overly conservative, because of actual limitations on the available mass of contaminant. The slow rate of removal (the gradational release of contaminants) coupled with dilution, dispersion, and degradation may eliminate the need for active groundwater removal and treatment. 


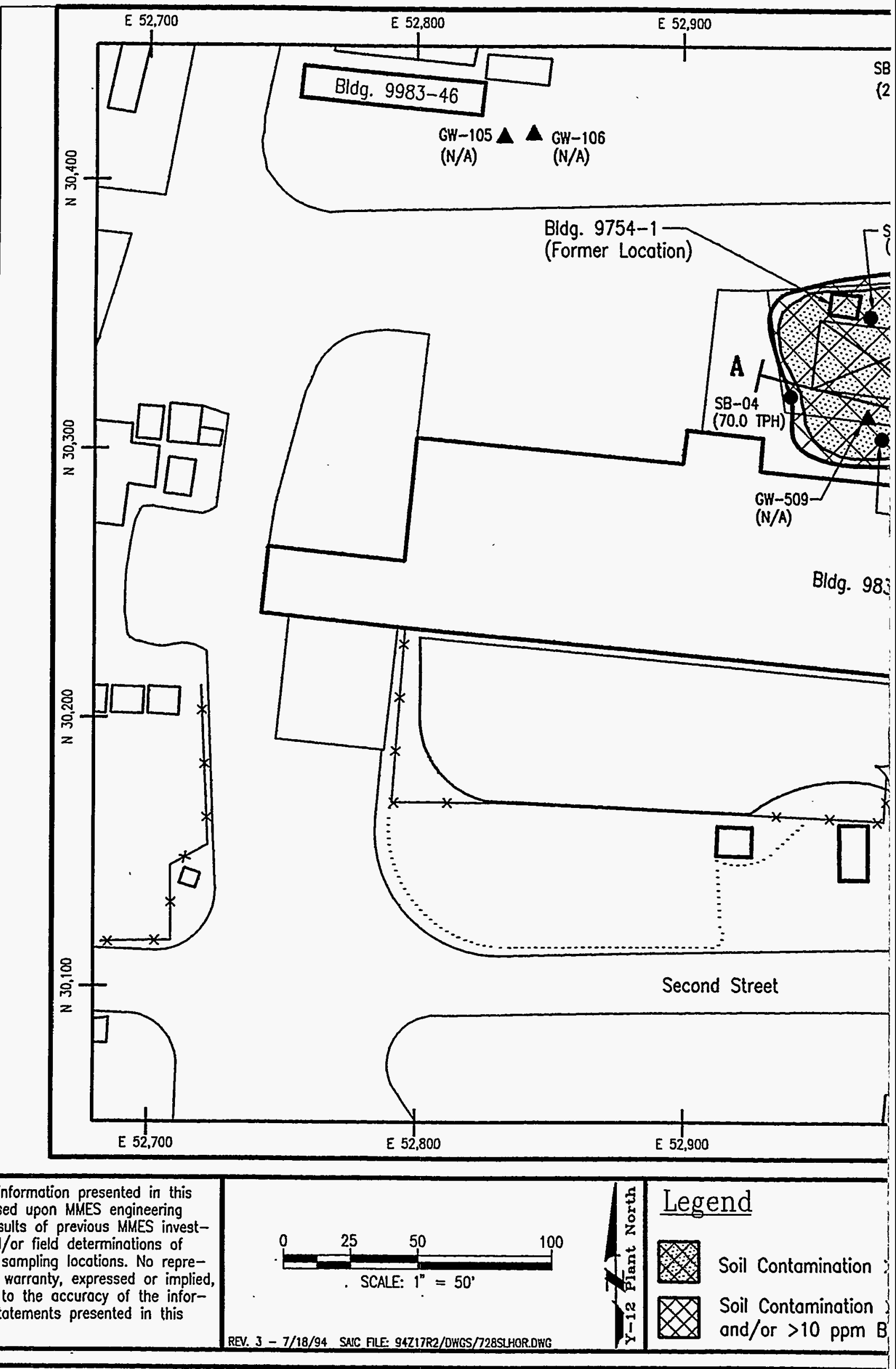

All locotion information presented in this figure is based upon MMES engineering drawings, results of previous MMES investigations, ond/or field determinations of feoture and sompling locations. No representation or warranty, expressed or implied, is made as to the occuracy of the informotion or statements presented in this figure. 


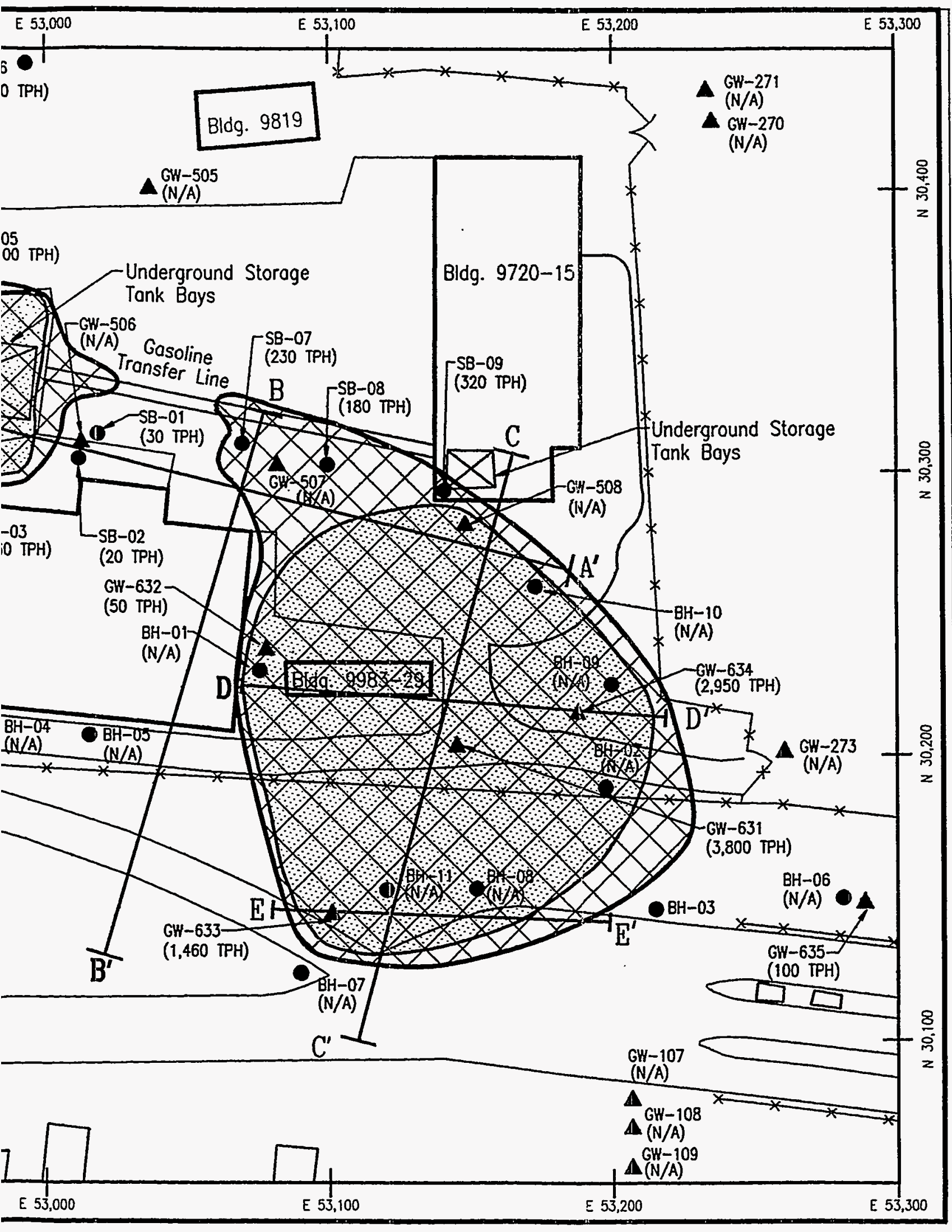

NOTE:

$00 \mathrm{ppm} \mathrm{TPH}$

00 ppm TPH
1) $N / A=$ Sample not analyzed for TPH.

2) Concentrations in parentheses in parts per million (ppm)
Martin Marietto Energy Systems, Inc. Environmental Management Department FIGURE B.1

Horizontal Extent of Soil Contamination at the Rust Garage Facility 


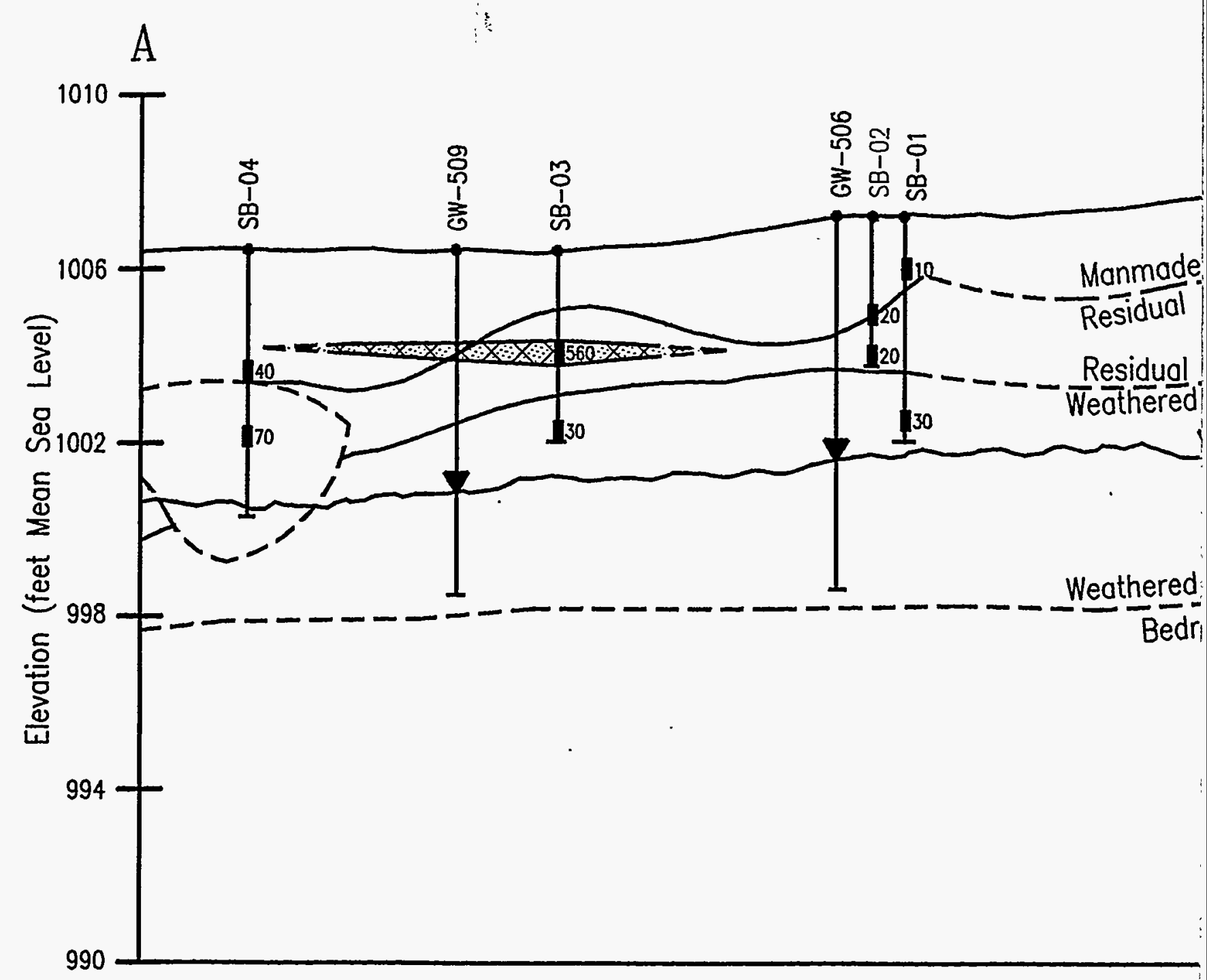

\begin{tabular}{|l|l|l|}
\hline $\begin{array}{l}\text { All location information presented in this } \\
\text { figure is bosed upon MMES engineering } \\
\text { drawings, results of previous MMES } \\
\text { investigotions, and/or field determinations } \\
\text { of feature ond sampling locotions. No } \\
\text { representation or worronty, expressed or } \\
\text { implied, is made os to the occuracy of } \\
\text { the information or stotements presented } \\
\text { in this figure. }\end{array}$ & Vertical Scale $5 \mathrm{X}$ horizontal scale & Soil Contamin \\
\hline
\end{tabular}




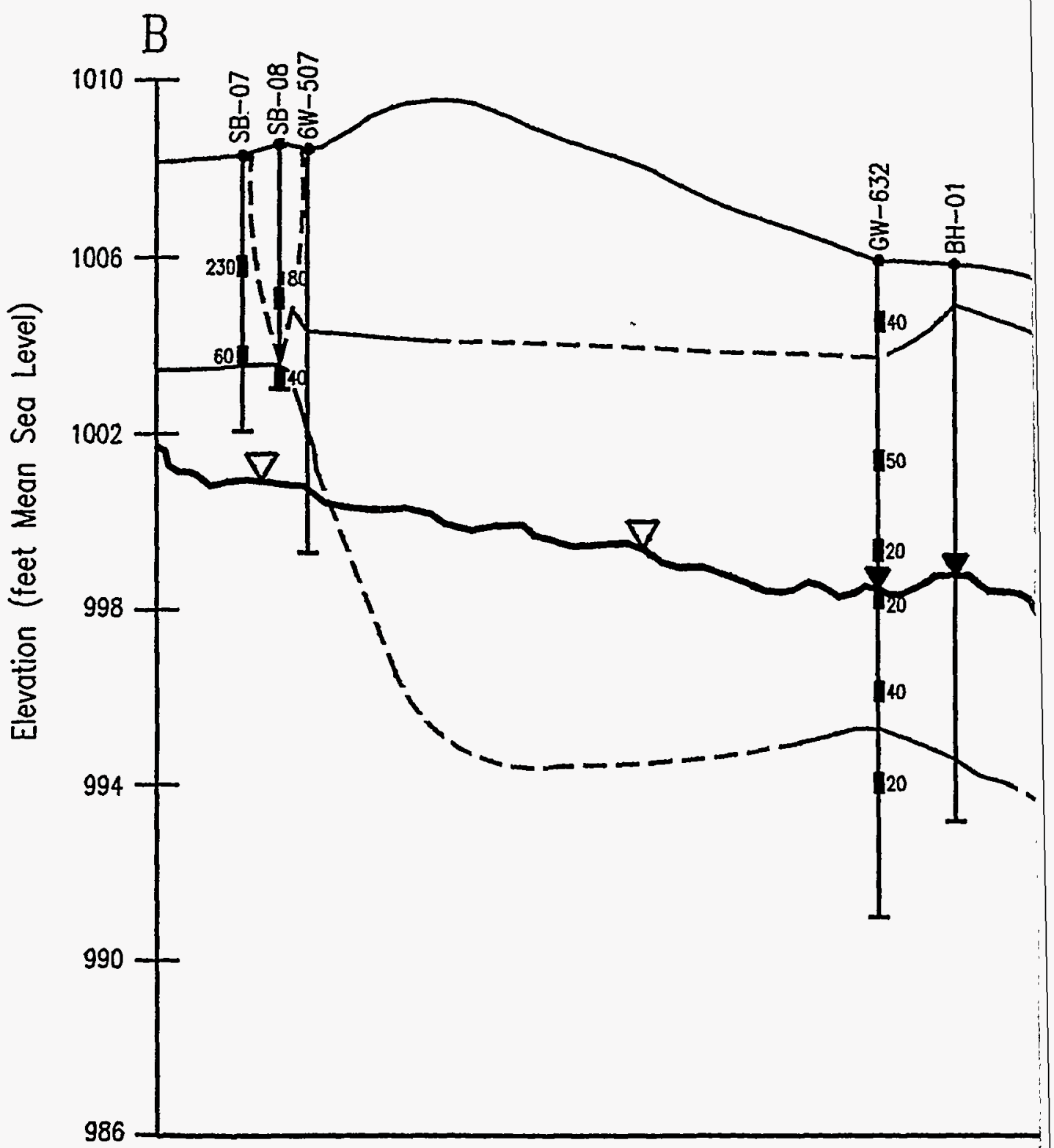

All locotion information presented in this figure is based upon MMES engineering drawings, results of previous MMES investigations, and/or field determinations of feature and sampling locations. No representation or warranty, expressed or implied, is made os to the accuracy of the information or stotements presented in this figure.

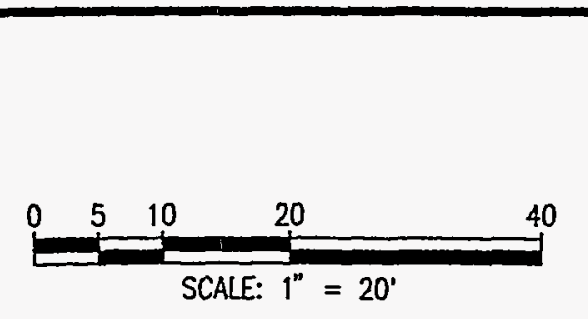

Vertical Scale $5 x$ horizontal scale

\section{LEGEND}

$\nabla \quad$ Inferred Woter

$\$ 50$

Sompled Inten TPH Concentro 


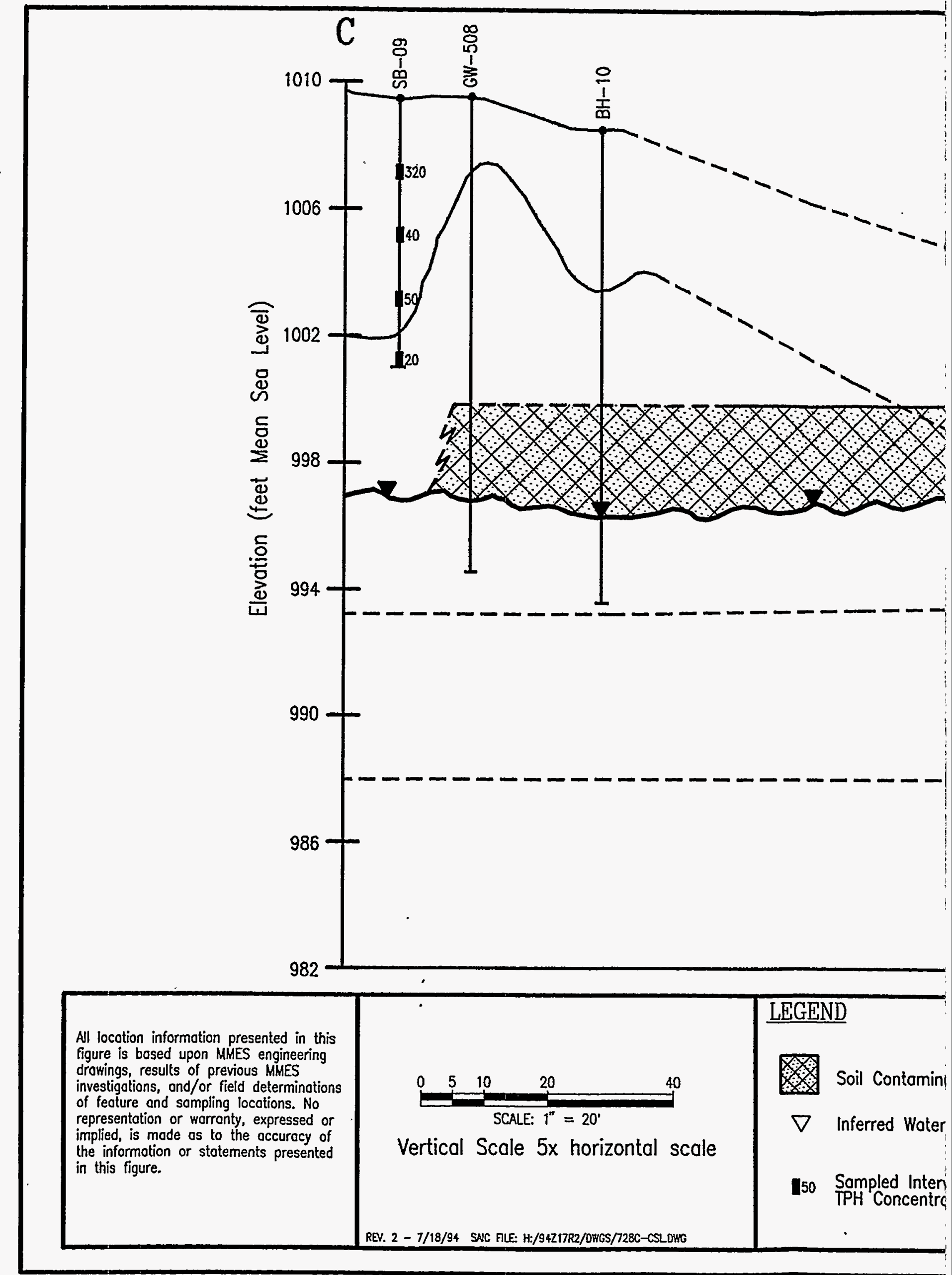




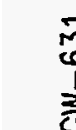
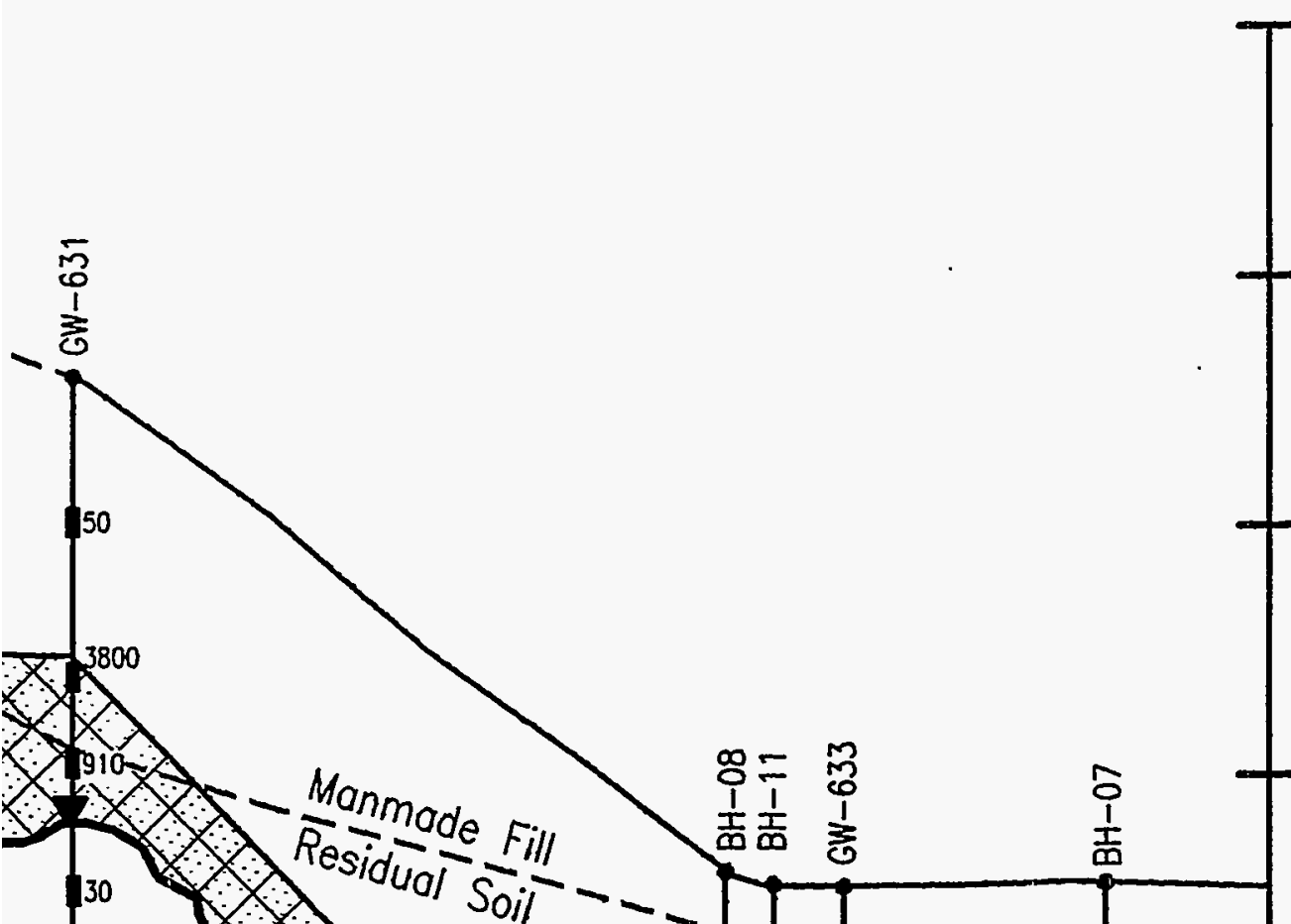

on

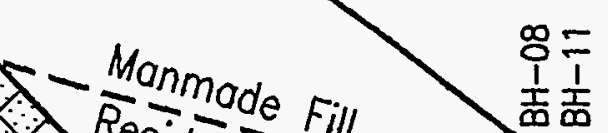
Residual Fill 吉志 产 dual Soil $\rightarrow$

30 SA So

150

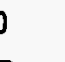
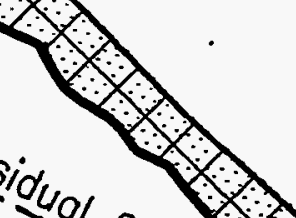

20

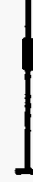

170

athered
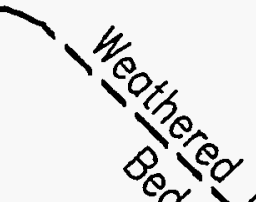

\%
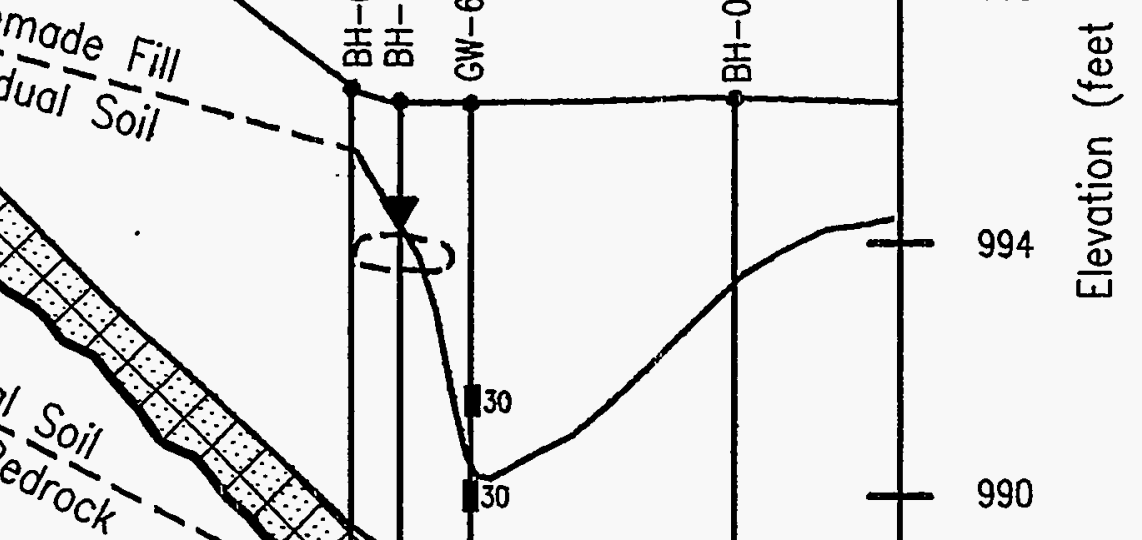

1002

क্

ติ

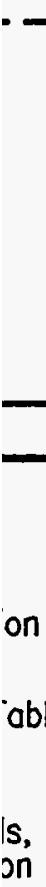

ab
on

500 ppm TPH

ble

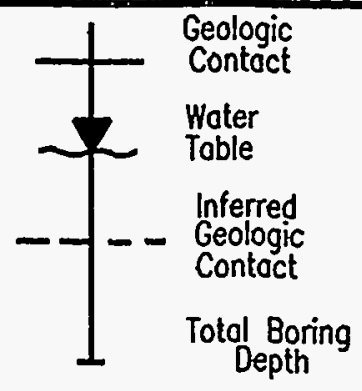

Z Totol Depth Scole

\section{2}

Martin Marietto Energy Systems, Inc.

Environmental Monagement Department

\section{FIGURE B.4}

Rust Garage Facility

Vertical Extent of Soil Contamination Along Geologic Cross-Section $\mathrm{C}^{-\mathrm{C}^{\prime}}$ 


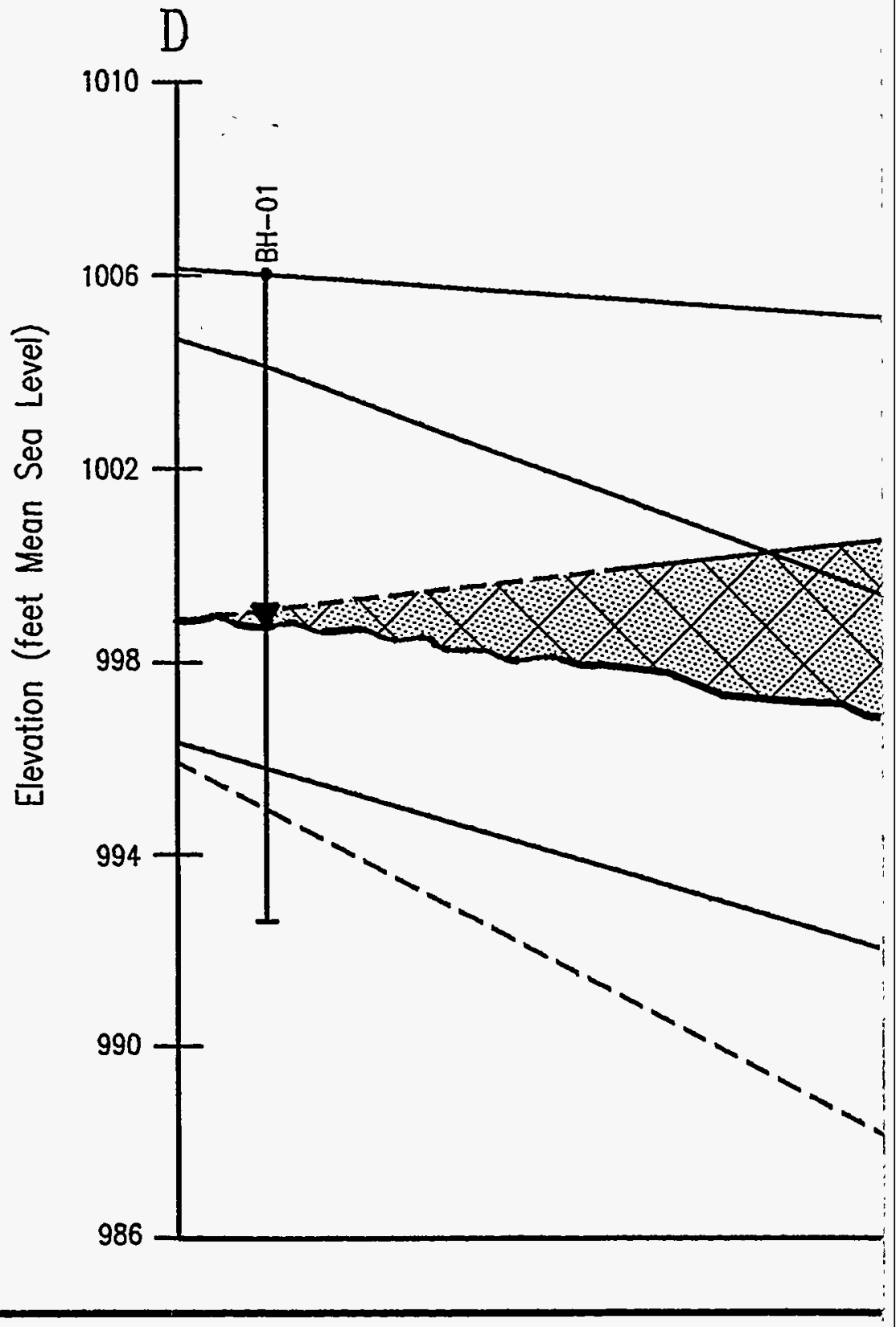

All location information presented in this figure is bosed upon MMES engineering drawings, results of previous MMES investigations, ond/or field determinotions of feoture and sampling locations. No representotion or worronty, expressed or implied, is made os to the occurocy of the information or stotements presented in this figure.

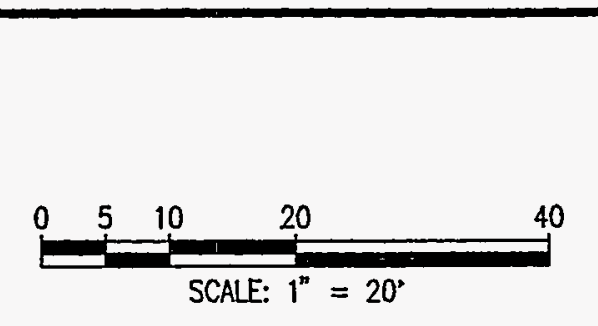

Vertical Scale $5 x$ horizontal scale

\section{LEGEND}

s

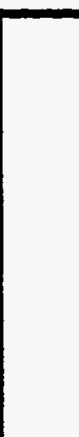




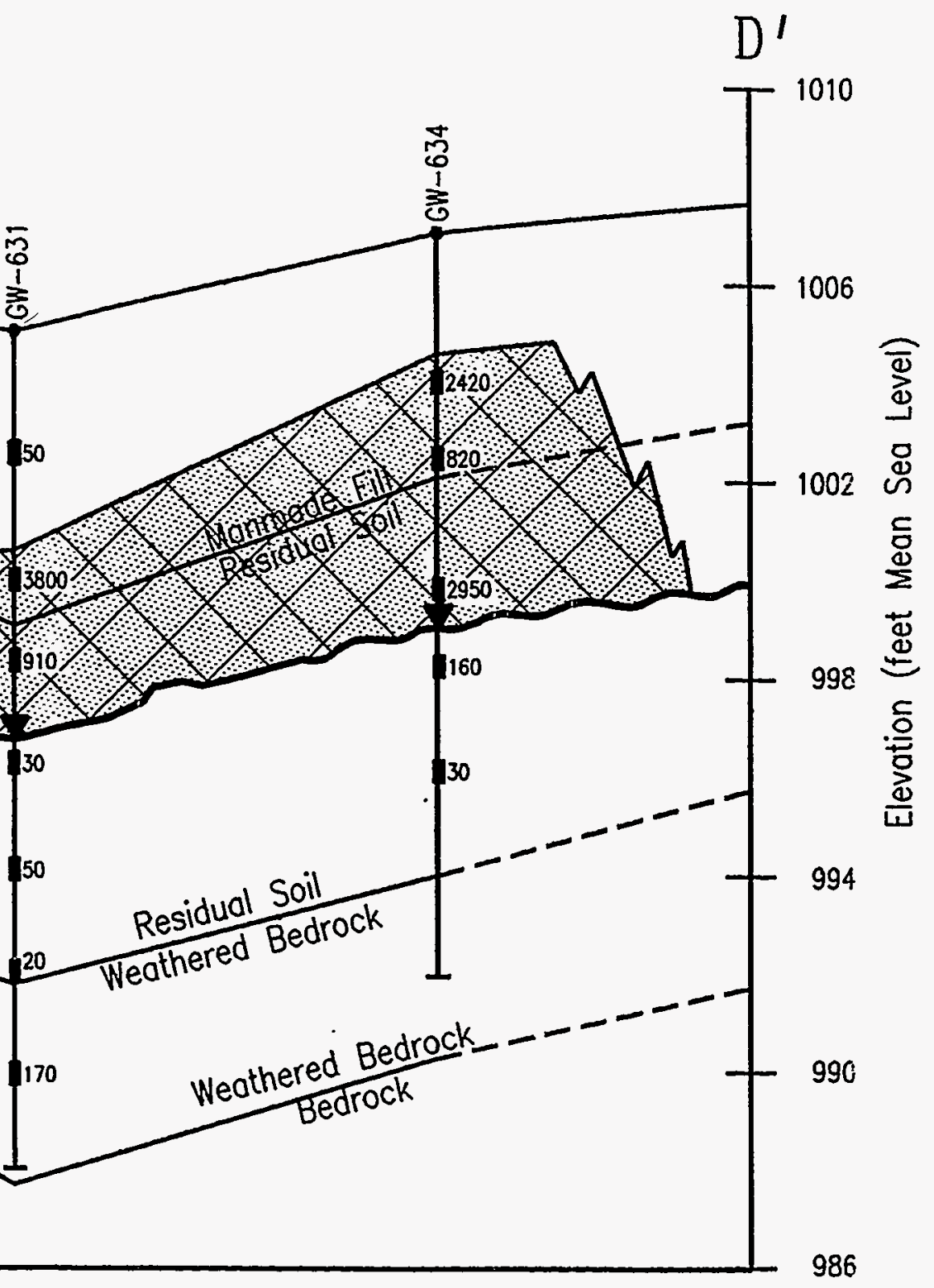

ion $>500 \mathrm{ppm} \mathrm{TPH}$

Table

als,

ion in $\mathrm{ppm}$

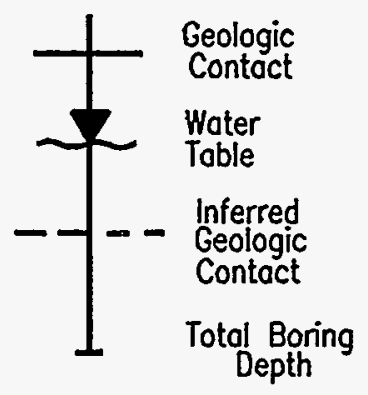

3 Total Depth Scale

Martin Marietto Energy Systems, Inc.

Environmentol Management Department

\section{FIGURE B.5}

Rust Garage Facility

Vertical Extent of Soil Contamination Along Geologic Cross-Section D-D 


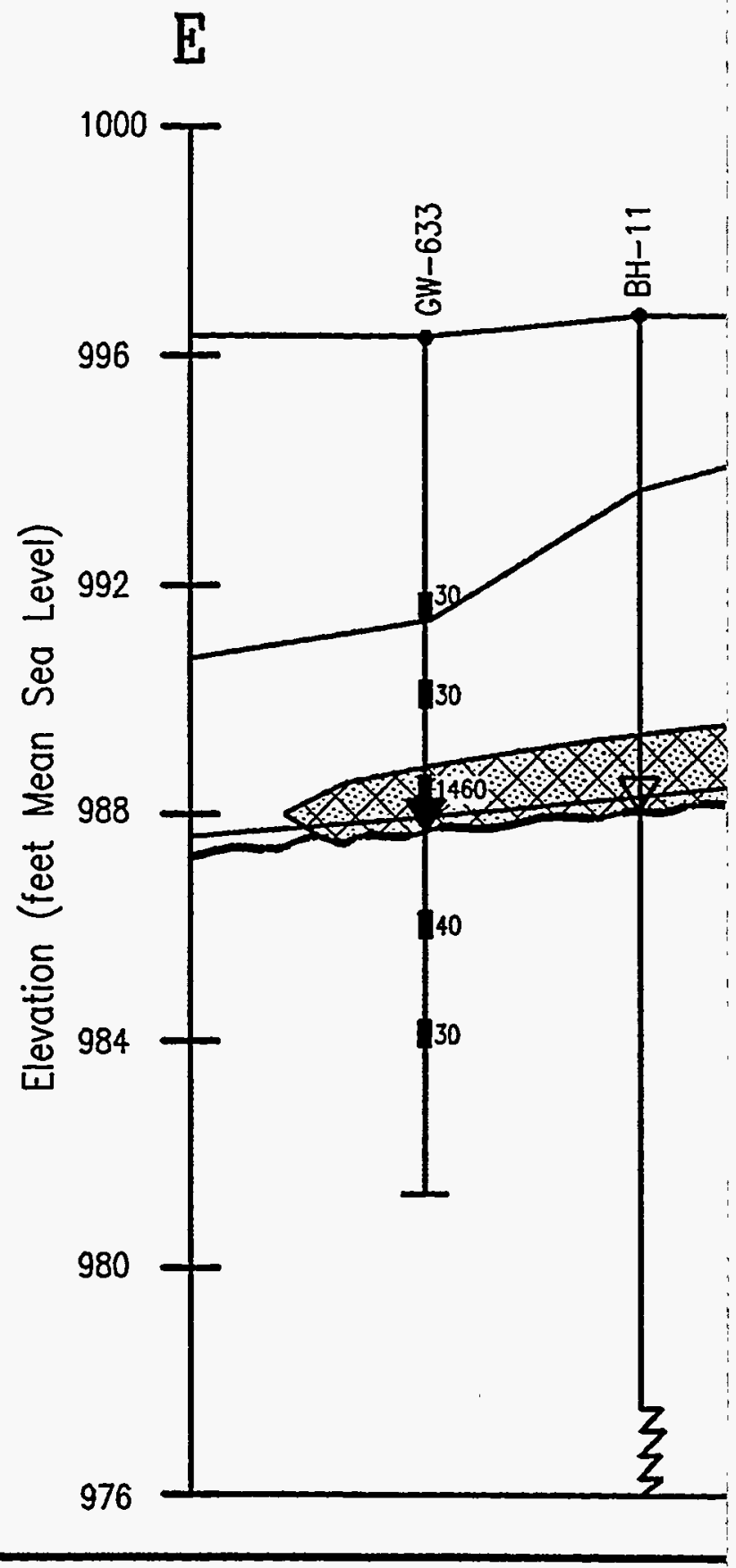

All location information presented in this figure is bosed upon MMES engineering drawings, results of previous MMES investigations, and/or field determinations of feature and sampling locations. No representation or warranty, expressed or implied, is made os to the occuracy of the information or statements presented in this figure.

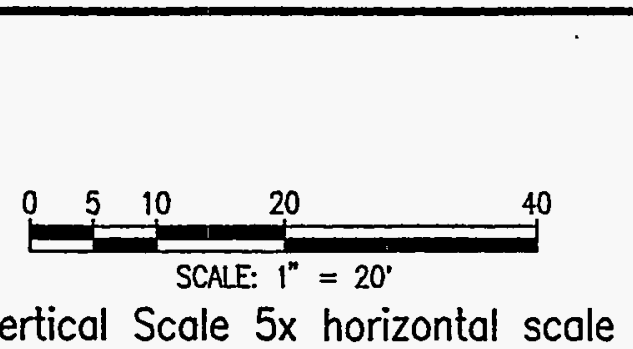

Vertical Scale $5 x$ horizontal scale
LEGEND

LEGLND

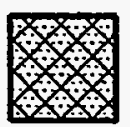

Soil Cont

$\nabla \quad$ Inferred V

150 Sampled 


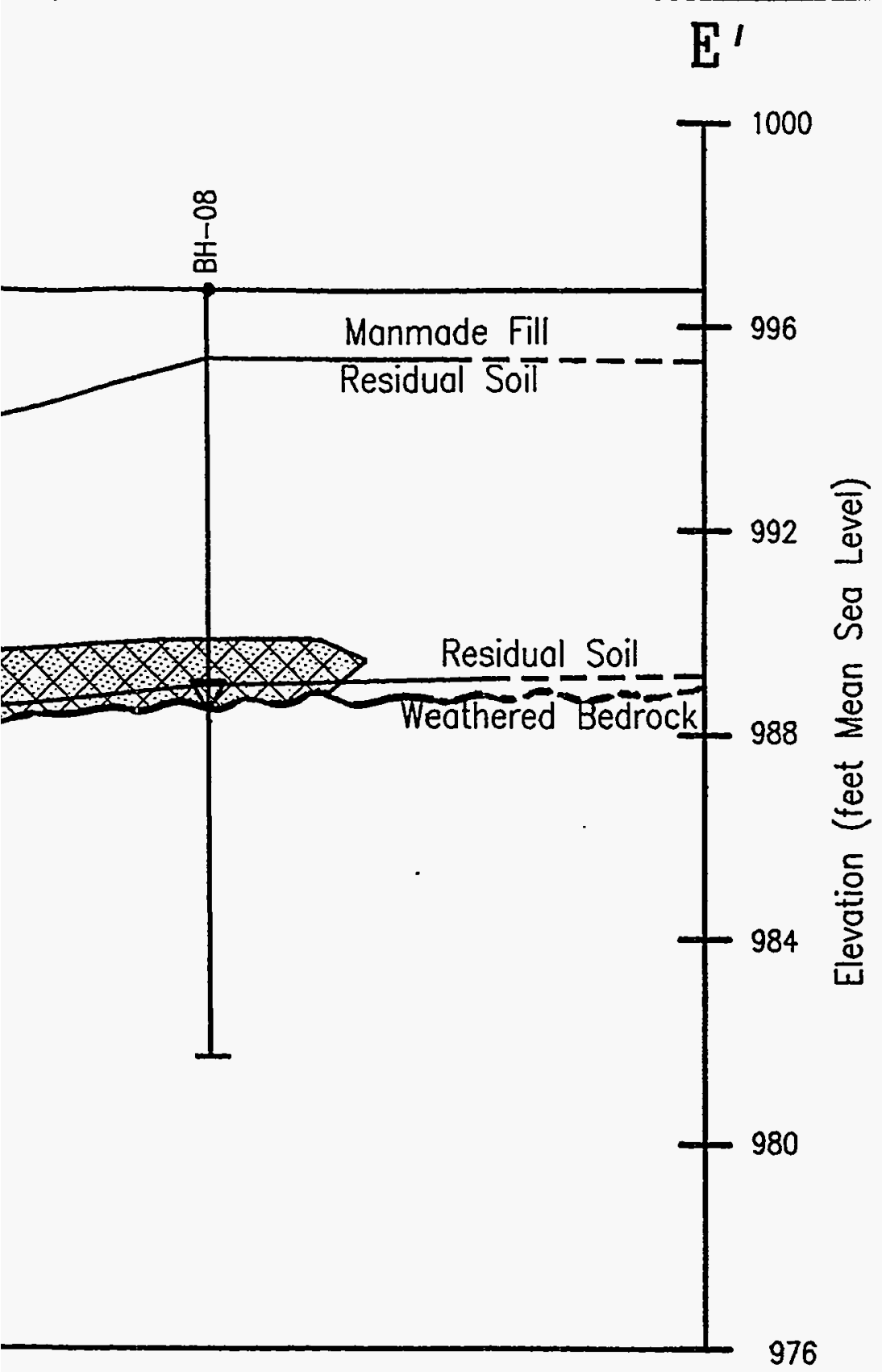

lination $>500 \mathrm{ppm}$ TPH

ter Toble

ervals,

itration in ppm

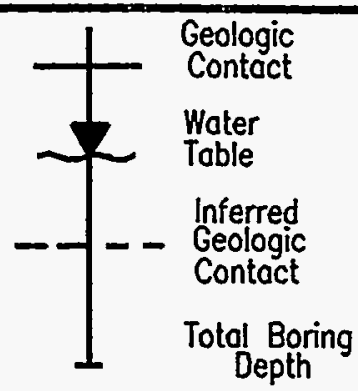

Z Totol Depth

3 Below Vertical Scale
Martin Marietta Energy Systems, Inc. Environmental Management Department

\section{FIGURE B.6}

Rust Garage Facility Vertical Extent of Soil Contamination Along Geologic Cross-Section E-E' 


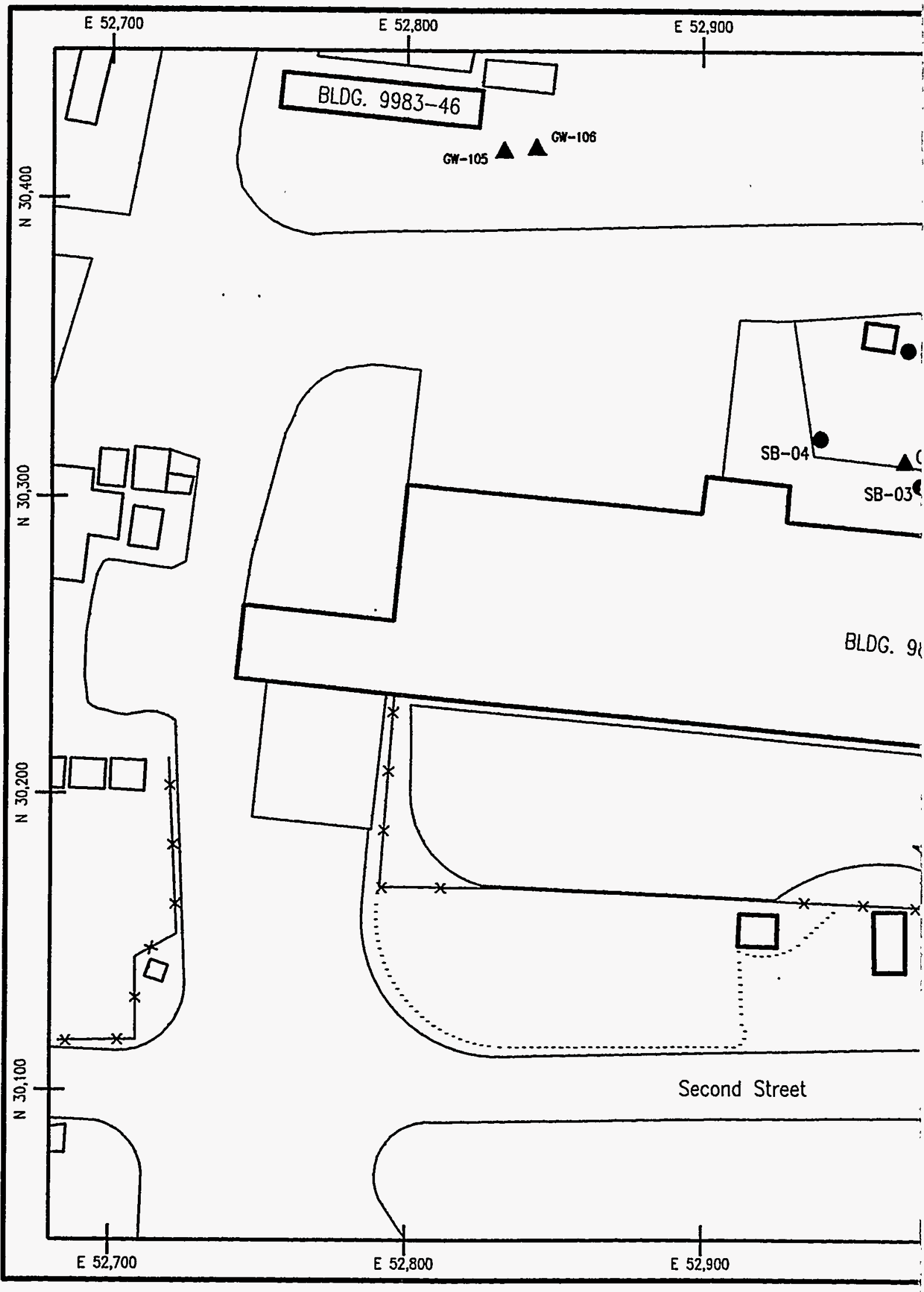

All location information presented in this figure is based upon MMES engineering drawings, results of previous MMES investigations, ond/or field determinations of feature and sompling locations. No representation or worranty, expressed or implied, is made os to the accuracy of the information or statements presented in this figure.

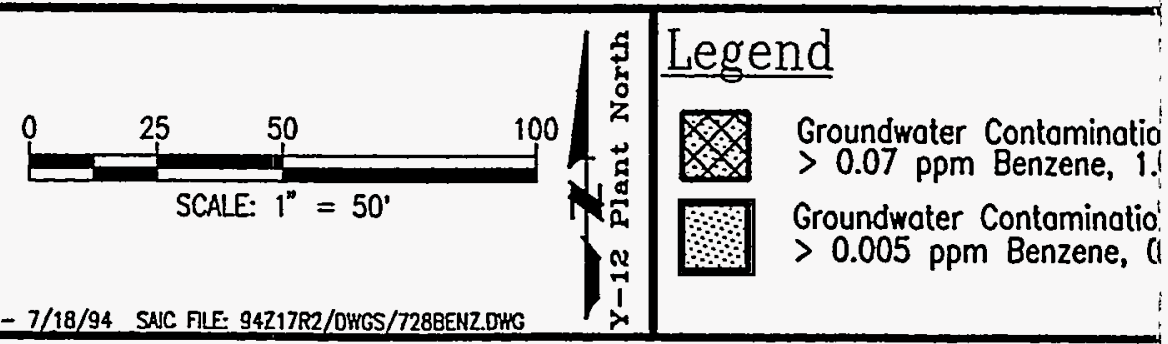




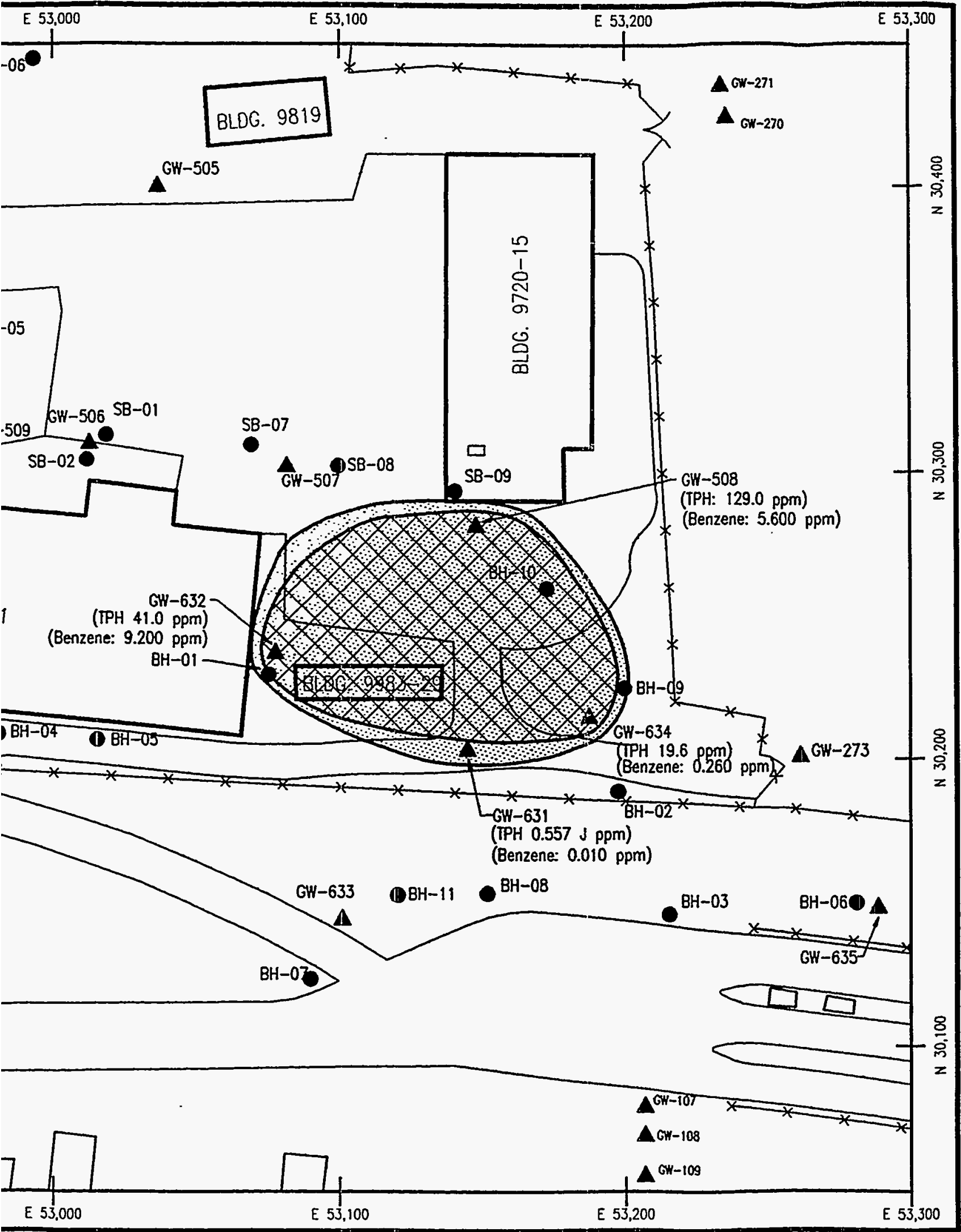

A GW-508 Monitoring Well Location - sa-0r Soir Boring Location \& Result for TPH \& BTX

(N/A) Not Analyzed
Martin Marietto Energy Systems, Inc. Environmental Manogement Department FIGURE B.7

Horizontal Extent of Benzene Contamination in Groundwater At The Rust Garage Facility 


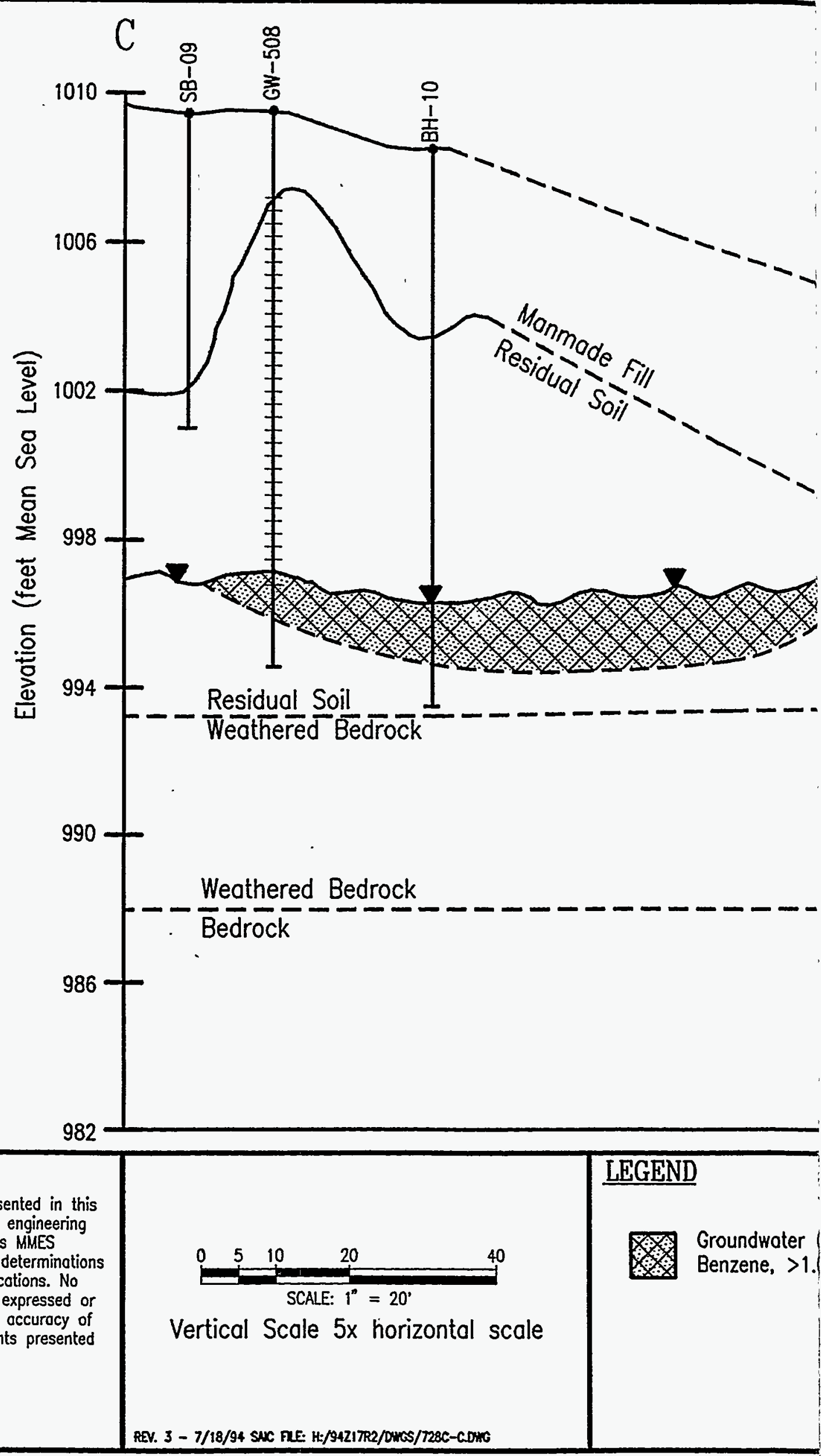

All locotion information presented in this figure is based upon MMES engineering drowings, results of previous MMES investigations, and/or field determinations of feature and sampling locotions. No representation or warranty, expressed or implied, is made os to the occurocy of the information or statements presented in this figure. 


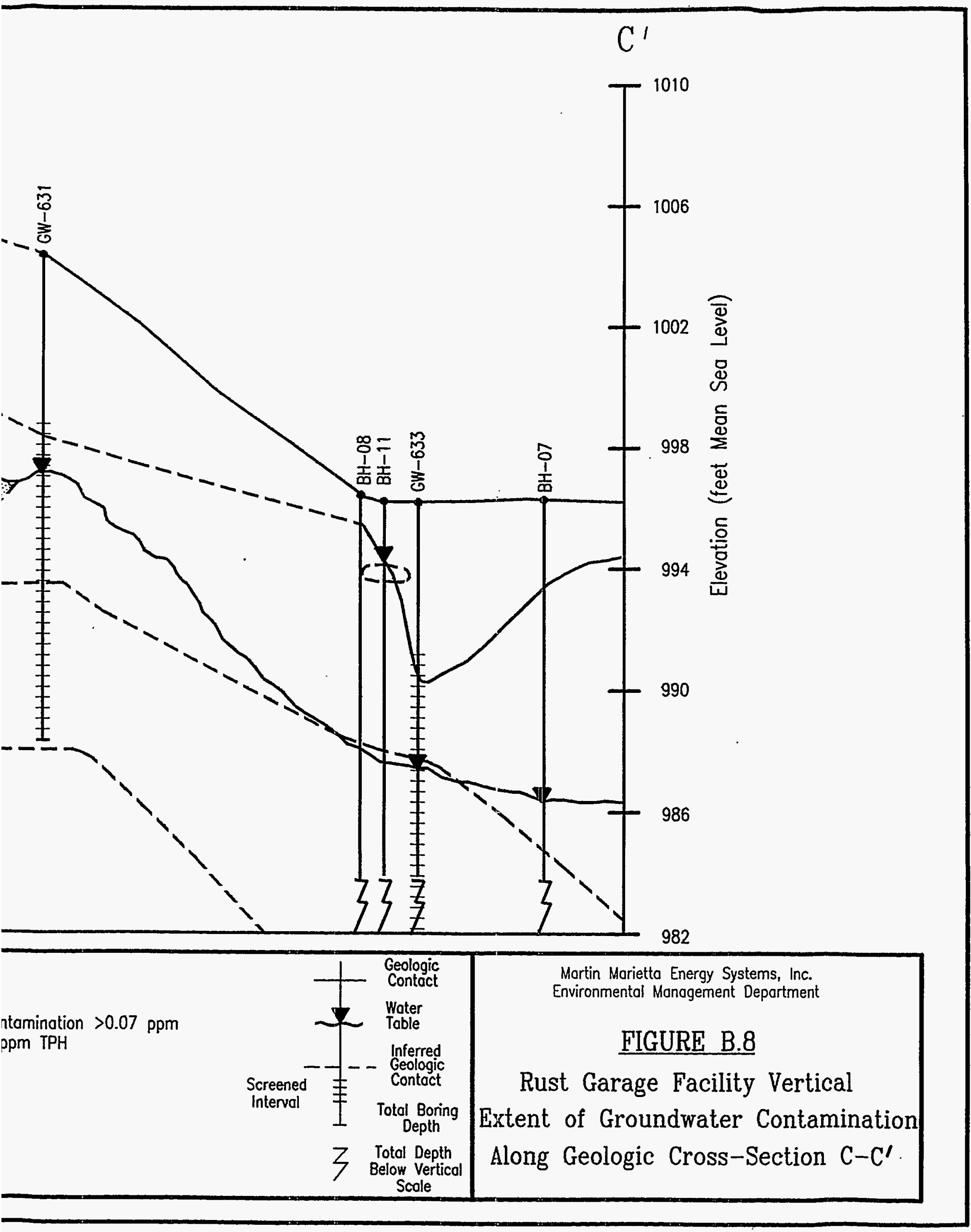




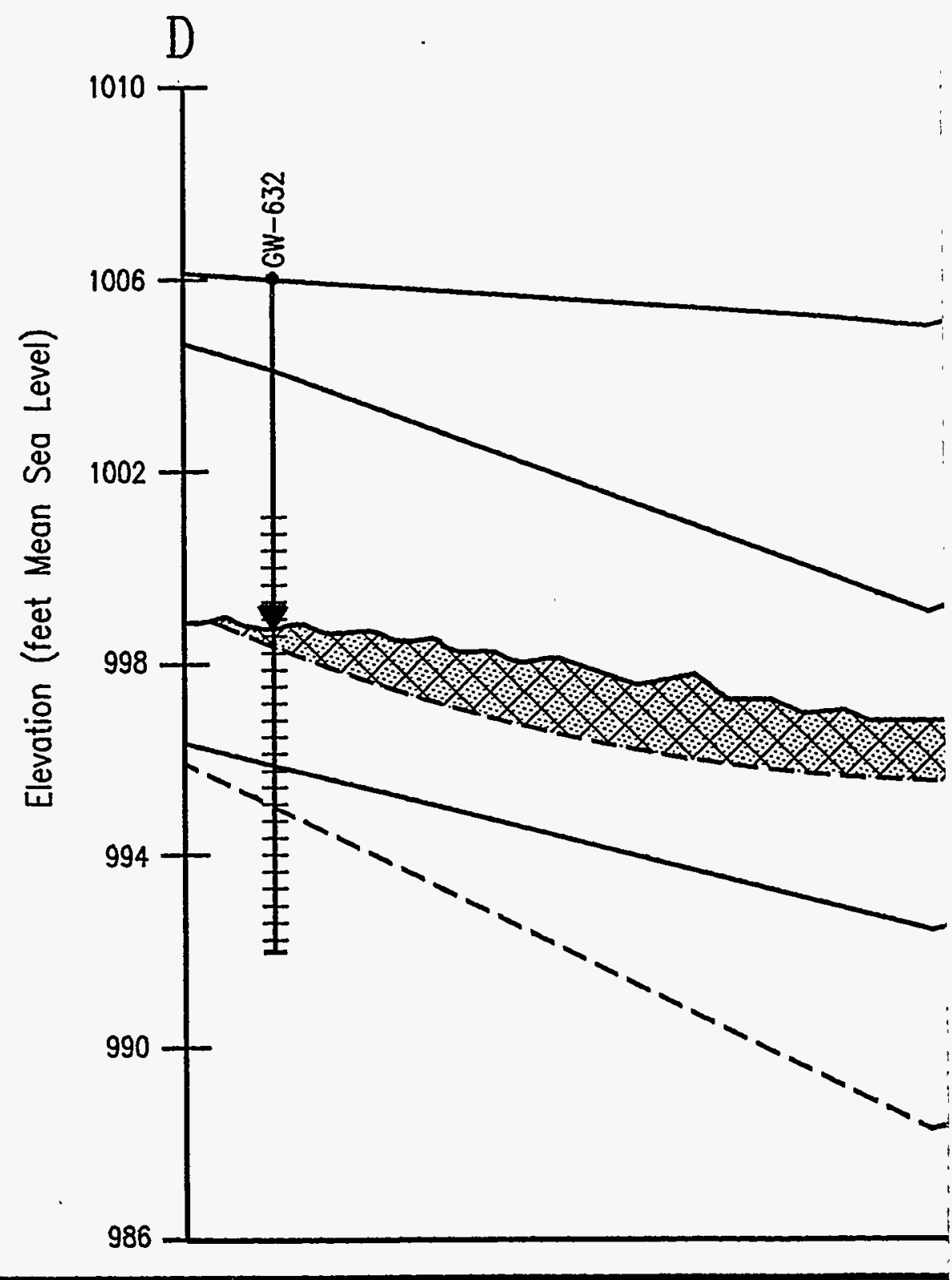

All location information presented in this figure is bosed upon MMES engineering drawings, results of previous MMES investigations, and/or field determinations of feoture and sompling locations. No representation or warronty, expressed or implied, is made as to the accuracy of

the information or statements presented in this figure.

\section{LEGEND}
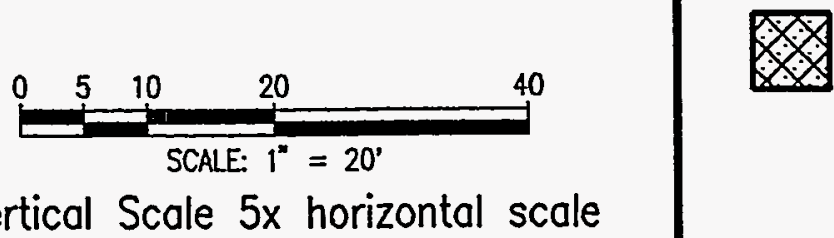

Groundwater $>1.0 \mathrm{ppm} \mathrm{T}$ 
Table B.1. Summary of Soil Analytical Data Generated from Investigations Conducted at the Rust Garage Facility

\begin{tabular}{|c|c|c|c|c|c|c|c|}
\hline \multicolumn{8}{|c|}{ Tank 1219-U, 1222-U, and 2082-U Removal - December 1989} \\
\hline $\begin{array}{l}\text { Contaminant: } \\
\text { Method: } \\
\text { Units: }\end{array}$ & $\begin{array}{c}\text { Benzene } \\
8240^{1} \\
(\mathrm{ppm})\end{array}$ & $\begin{array}{c}\text { Toluene } \\
8240^{1} \\
\text { (ppm) }\end{array}$ & $\begin{array}{c}\text { Xylenes } \\
8240^{1} \\
\text { (ppm) }\end{array}$ & $\begin{array}{c}\text { Ethylbenzene } \\
8240^{1} \\
(\mathrm{ppm})\end{array}$ & $\begin{array}{c}\text { Total } \\
\text { Petroleum } \\
\text { Hydrocarbons } \\
\text { E-418.1 } \\
\text { (ppm) }\end{array}$ & $\begin{array}{l}\text { Lead } \\
6010^{3} \\
(\mathrm{ppm})\end{array}$ & $\begin{array}{c}\text { Total } \\
\Sigma \text { BTEX } \\
\text { (ppm) }\end{array}$ \\
\hline \multicolumn{8}{|c|}{ Sample Number/Interval } \\
\hline \multicolumn{8}{|l|}{ Pit Soil } \\
\hline $\begin{array}{l}\left(8.0^{\prime}-10.0^{\prime}\right) \\
\text { TRS-2-89 }\end{array}$ & $0.010 \mathrm{U}^{4}$ & 0.085 & 0.019 & $0.010 \mathrm{U}$ & $N A^{5}$ & $<19.0$ & 0.104 \\
\hline $\begin{array}{l}\left(8.0^{\prime}-10.0^{\prime}\right) \\
\text { TRS-3-89 }\end{array}$ & $0.010 \mathrm{U}$ & $0.743 \mathrm{~J}^{6}$ & 0.260 & 0.076 & NA & $<19.0$ & 1.07 \\
\hline $\begin{array}{l}\left(8.0^{\prime}-10.0^{\prime}\right) \\
\text { TRS-4-89 }\end{array}$ & 0.013 & $11.06 \mathrm{~J}$ & 3.90 & 0.920 & NA & $<16.0$ & $* 15.89$ \\
\hline$\left(8.0^{\prime}-10.0^{\prime}\right)$ & $0.010 \mathrm{~J}$ & $1.65 \mathrm{~J}$ & 0.430 & 0.063 & NA & $<21.0$ & 2.14 \\
\hline \multicolumn{8}{|l|}{ Spoil Pile } \\
\hline $\begin{array}{l}\text { SP-1-89 } \\
\quad \text { (Grab) } \\
\text { SP-2-89 }\end{array}$ & $0.010 \mathrm{U}$ & $0.587 \mathrm{~J}$ & 0.150 & 0.026 & NA & $<20.0$ & 0.763 \\
\hline $\begin{array}{l}\text { (Grab) } \\
\text { SP-3-90 }\end{array}$ & $0.010 U$ & $0.767 \mathrm{~J}$ & 0.017 & 0.080 & NA & $<9.2$ & 0.864 \\
\hline $\begin{array}{l}\text { (North Face) } \\
\text { SP-4-90 }\end{array}$ & $0.010 \mathrm{U}$ & $0.010 \mathrm{U}$ & 0.290 & $0.010 \mathrm{U}$ & 760 & 30.0 & 0.290 \\
\hline $\begin{array}{l}\text { (East Face) } \\
\text { SP-5-90 }\end{array}$ & $0.010 \mathrm{U}$ & $0.010 \mathrm{U}$ & 0.390 & $0.010 \mathrm{U}$ & *1640 & $<20.0$ & 0.390 \\
\hline $\begin{array}{l}\text { (South Face) } \\
\text { SP-6-90 }\end{array}$ & $0.010 \mathrm{U}$ & $0.010 \mathrm{U}$ & 0.500 & $0.010 \mathrm{U}$ & 1840 & 20.0 & 0.500 \\
\hline (West Face) & $0.010 \mathrm{U}$ & $0.010 \mathrm{U}$ & 0.700 & $0.010 \mathrm{U}$ & 970 & 20.0 & 0.700 \\
\hline
\end{tabular}


Table B.1 (continued)

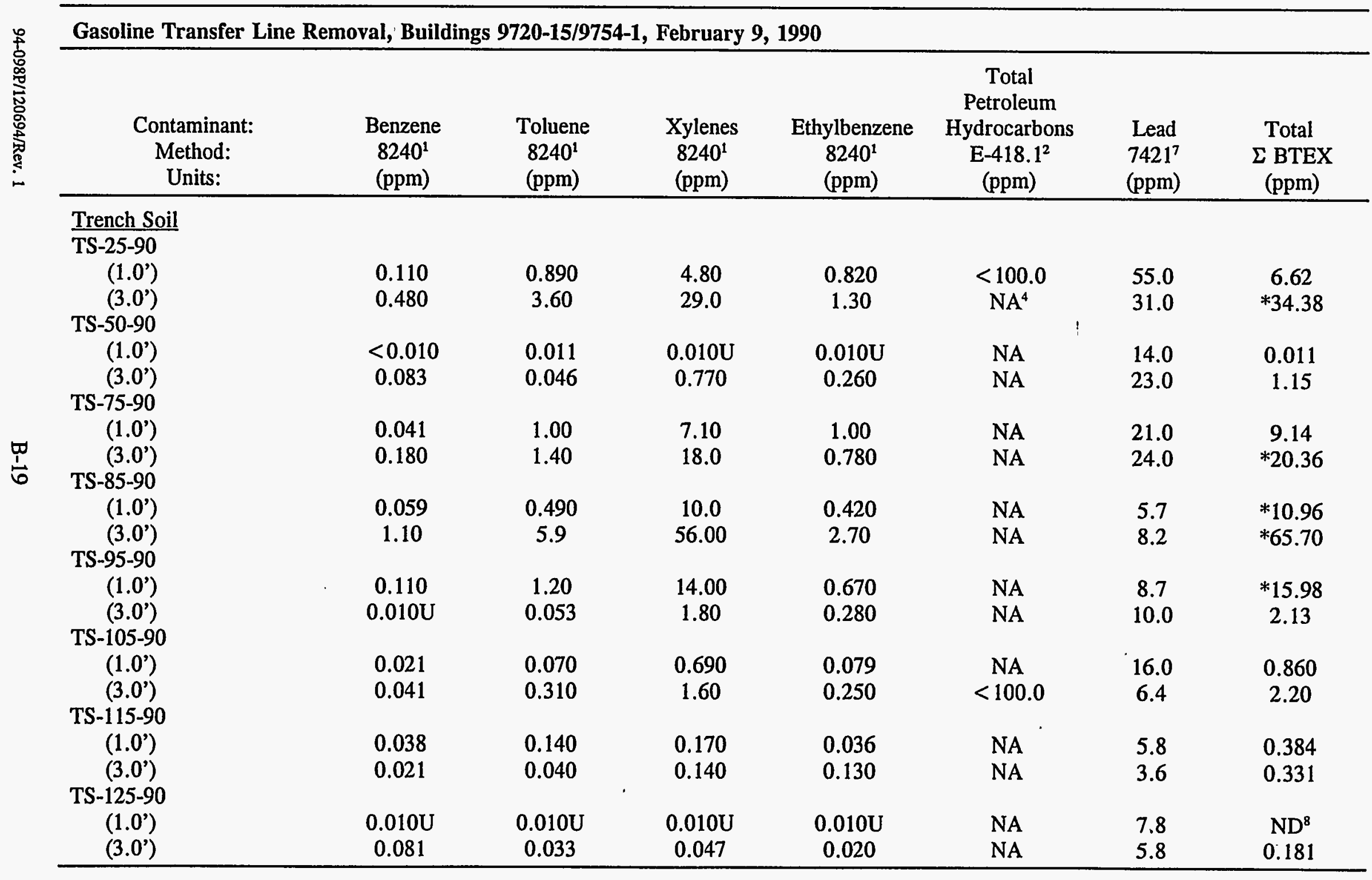


Table B.1 (continued)

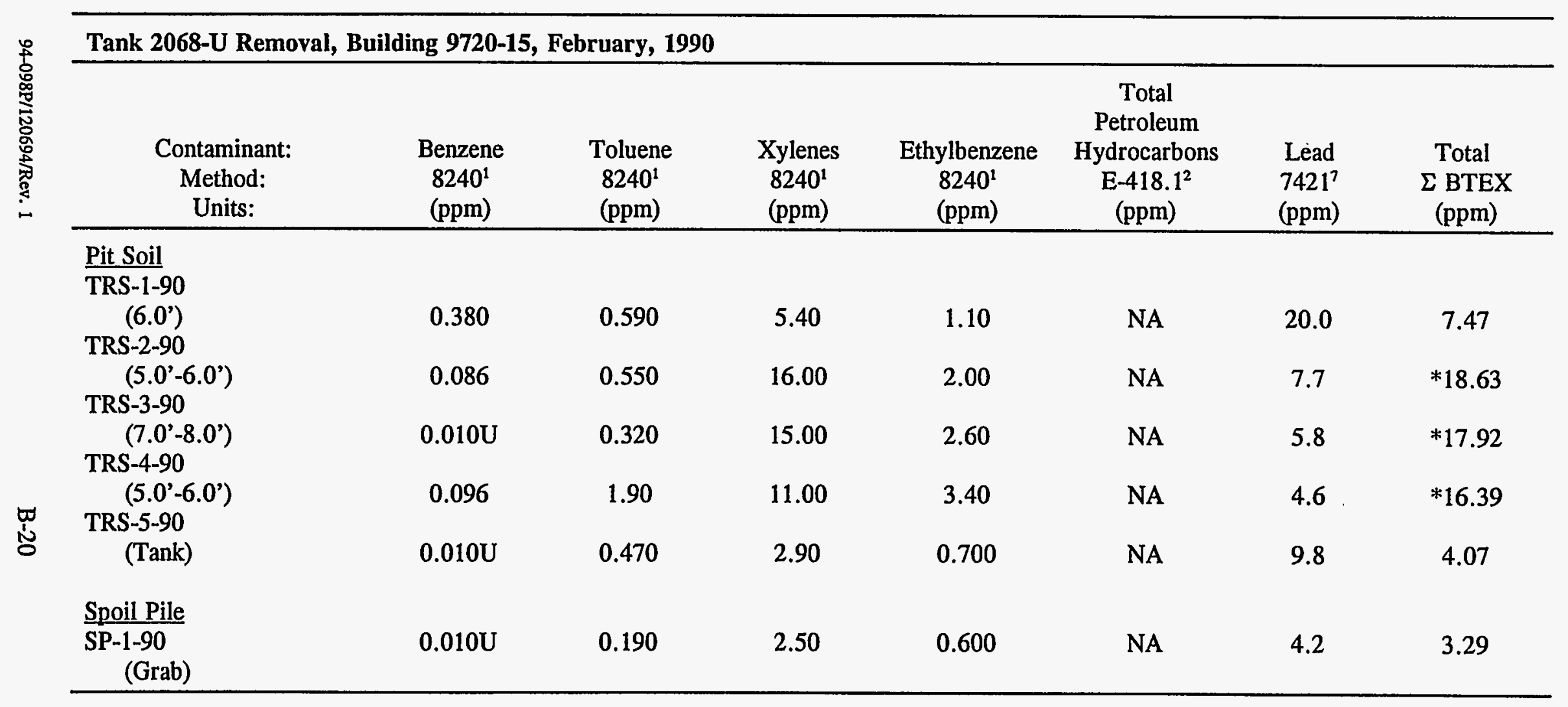


Table B.1 (continued)

\begin{tabular}{|c|c|c|c|c|c|c|c|}
\hline \multicolumn{8}{|c|}{ Site Investigation, Buildings 9720-15/9754-1, May 1990} \\
\hline $\begin{array}{l}\text { Contaminant: } \\
\text { Method: } \\
\text { Units: }\end{array}$ & $\begin{array}{c}\text { Benzene } \\
8240^{1} \\
\text { (ppm) }\end{array}$ & $\begin{array}{c}\text { Toluene } \\
8240^{1} \\
\text { (ppm) }\end{array}$ & $\begin{array}{c}\text { Xylenes } \\
8240^{1} \\
\text { (ppm) }\end{array}$ & $\begin{array}{c}\text { Ethylbenzene } \\
8240^{1} \\
(\mathrm{ppm})\end{array}$ & $\begin{array}{c}\text { Total } \\
\text { Petroleum } \\
\text { Hydrocarbons } \\
\text { 503D, 503E } \\
(\mathrm{ppm})\end{array}$ & $\begin{array}{l}\text { Lead } \\
7420^{10} \\
(\mathrm{ppm})\end{array}$ & $\begin{array}{c}\text { Total } \\
\Sigma \text { BTEX } \\
\text { (ppm) }\end{array}$ \\
\hline \multicolumn{2}{|l|}{ SB-01-90 } & & & & & & \\
\hline$\left(1.0^{\prime}-1.5^{\prime}\right)$ & $0.010 \mathrm{U}$ & $0.010 \mathrm{U}$ & $0.010 \mathrm{U}$ & $0.010 \mathrm{U}$ & 10.0 & 22.0 & ND \\
\hline$\left(4.5^{\prime}-5.0^{\prime}\right)$ & $0.010 \mathrm{U}$ & $0.010 \mathrm{U}$ & $0.010 \mathrm{U}$ & $0.010 \mathrm{U}$ & 30.0 & 15.0 & ND \\
\hline \multicolumn{8}{|l|}{ SB-02-90 } \\
\hline$\left(2.0^{\prime}-2.5^{\prime}\right)$ & $0.010 U$ & $0.010 \mathrm{U}$ & $0.010 \mathrm{U}$ & $0.010 \mathrm{U}$ & 20.0 & 18.0 & ND \\
\hline$\left(3.0^{\prime}-3.4^{\prime}\right)$ & $0.010 \mathrm{U}$ & $0.010 \mathrm{U}$ & $0.010 \mathrm{U}$ & $0.010 \mathrm{U}$ & 20.0 & 19.0 & ND \\
\hline \multicolumn{8}{|l|}{ SB-03-90 } \\
\hline$\left(2.0^{\prime}-2.5^{\prime}\right)$ & $0.010 \mathrm{U}$ & $0.010 \mathrm{U}$ & $0.010 \mathrm{U}$ & $0.060 \mathrm{~J}$ & $* 560.0$ & 61.0 & 0.060 \\
\hline \multicolumn{8}{|l|}{ SB-04-90 } \\
\hline$\left(2.5^{\prime}-3.0^{\prime}\right)$ & $0.010 \mathrm{U}$ & $0.010 \mathrm{U}$ & $0.010 \mathrm{U}$ & $0.010 \mathrm{U}$ & 40.0 & 49.0 & ND \\
\hline$\left(4.0^{\prime}-4.5^{\prime}\right)$ & $0.010 \mathrm{U}$ & $0.010 \mathrm{U}$ & $0.010 \mathrm{U}$ & $0.010 \mathrm{U}$ & 70.0 & 11.0 & ND \\
\hline \multicolumn{8}{|l|}{ SB-05-90 } \\
\hline$\left(2.0^{\prime}-2.5^{\prime}\right)$ & $0.010 \mathrm{U}$ & $0.010 \mathrm{U}$ & $0.010 \mathrm{U}$ & $0.010 \mathrm{U}$ & $* 2100.0$ & 90.0 & ND \\
\hline$\left(4.0^{\prime}-4.5^{\prime}\right)$ & $0.010 \mathrm{U}$ & $0.010 \mathrm{U}$ & $0.010 \mathrm{U}$ & $0.010 \mathrm{U}$ & 20.0 & 5.8 & ND \\
\hline$\left(6.0^{\prime}-6.5^{\prime}\right)$ & $0.010 \mathrm{U}$ & $0.010 \mathrm{U}$ & $0.010 \mathrm{U}$ & $0.010 \mathrm{U}$ & 20.0 & 27.0 & ND \\
\hline$\left(7.5^{\prime}-8.0^{\prime}\right)$ & $0.010 \mathrm{U}$ & $0.010 \mathrm{U}$ & $0.010 \mathrm{U}$ & $0.010 \mathrm{U}$ & 40.0 & 4.8 & ND \\
\hline \multicolumn{8}{|l|}{ SB-06-90 } \\
\hline$\left(2.0^{\prime}-2.5^{\prime}\right)$ & $0.010 \mathrm{U}$ & $0.010 \mathrm{U}$ & $0.010 \mathrm{U}$ & $0.010 \mathrm{U}$ & $* 1460.0$ & 166.0 & ND \\
\hline$\left(4.0^{\prime}-4.5^{\prime}\right)$ & $0.010 \mathrm{U}$ & $0.010 U$ & $0.010 \mathrm{U}$ & $0.010 U$ & 40.0 & 19.0 & ND \\
\hline$\left(7.0^{\prime}-7.5^{\prime}\right)$ & $0.010 \mathrm{U}$ & $0.010 \mathrm{U}$ & $0.010 \mathrm{U}$ & $0.010 \mathrm{U}$ & 30.0 & 18.0 & ND \\
\hline$\left(8.0^{\prime}-8.5^{\prime}\right)$ & $0.010 \mathrm{U}$ & $0.010 \mathrm{U}$ & $0.010 \mathrm{U}$ & $0.010 \mathrm{U}$ & $* 2420.0$ & 20.0 & ND \\
\hline
\end{tabular}


Table B.1 (continued)

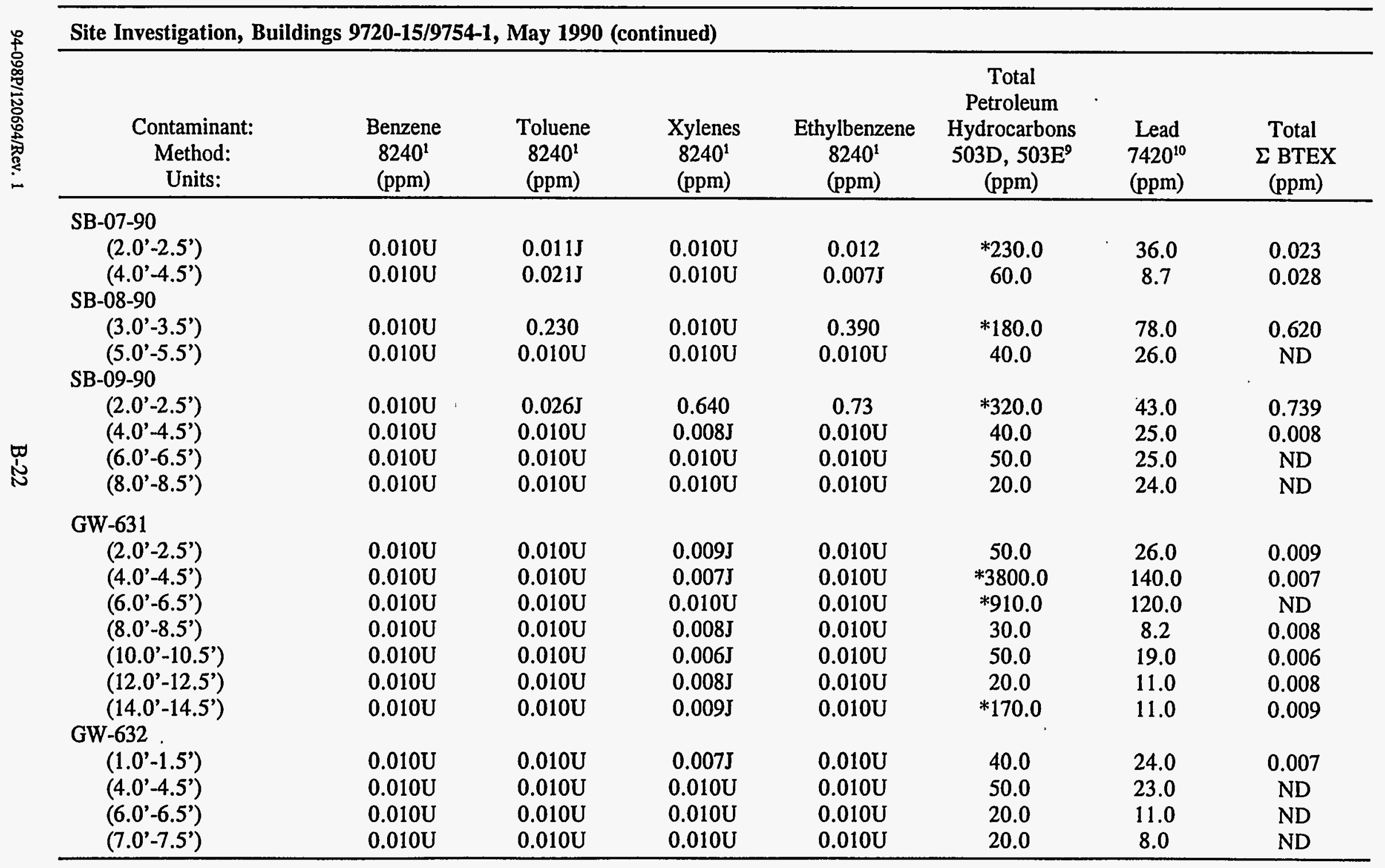


Table B.1 (continued)

\begin{tabular}{|c|c|c|c|c|c|c|c|}
\hline \multicolumn{8}{|c|}{ Site Investigation, Buildings 9720-15/9754-1, May 1990 (continued) } \\
\hline $\begin{array}{l}\text { Contaminant: } \\
\text { Method: } \\
\text { Units: }\end{array}$ & $\begin{array}{c}\text { Benzene } \\
8240^{1} \\
\text { (ppm) }\end{array}$ & $\begin{array}{c}\text { Toluene } \\
8240^{1} \\
\text { (ppm) }\end{array}$ & $\begin{array}{l}\text { Xylenes } \\
8240^{1} \\
\text { (ppm) }\end{array}$ & $\begin{array}{c}\text { Ethylbenzene } \\
8240^{1} \\
(\mathrm{ppm})\end{array}$ & $\begin{array}{c}\text { Total } \\
\text { Petroleum } \\
\text { Hydrocarbons } \\
\text { 503D, 503E } \\
(\mathrm{ppm})\end{array}$ & $\begin{array}{l}\text { Lead } \\
7420^{10} \\
(\mathrm{ppm}) \\
\end{array}$ & $\begin{array}{c}\text { Total } \\
\Sigma \text { BTEX } \\
(\mathrm{ppm})\end{array}$ \\
\hline$\left(9.0^{\prime}-9.5^{\prime}\right)$ & $0.010 \mathrm{U}$ & $0.010 \mathrm{U}$ & 0.330 & $0.010 \mathrm{U}$ & 40.0 & 20.0 & 0.330 \\
\hline$\left(11.0^{\prime}-11.5^{\prime}\right)$ & $0.010 \mathrm{U}$ & $0.010 \mathrm{U}$ & $0.010 \mathrm{U}$ & $0.010 \mathrm{U}$ & 20.0 & 30.0 & ND \\
\hline \multicolumn{8}{|l|}{ GW-633 } \\
\hline$\left(4.5^{\prime}-5.0^{\prime}\right)$ & $0.010 \mathrm{U}$ & $0.010 U$ & $0.010 \mathrm{U}$ & $0.010 \mathrm{U}$ & 30.0 & 29.0 & ND \\
\hline$\left(6.0^{\prime}-6.5^{\prime}\right)$ & $0.010 \mathrm{U}$ & $0.010 \mathrm{U}$ & $0.010 \mathrm{U}$ & $0.010 \mathrm{U}$ & 30.0 & 19.0 & ND \\
\hline$\left(8.0^{\prime}-8.5^{\prime}\right)$ & $0.010 \mathrm{U}$ & $0.010 \mathrm{U}$ & $0.010 \mathrm{U}$ & $0.010 \mathrm{U}$ & $* 1460.0$ & 36.0 & ND \\
\hline$\left(10.0^{\prime}-10.5^{\prime}\right)$ & $0.010 \mathrm{U}$ & $0.010 \mathrm{U}$ & $0.010 \mathrm{U}$ & $0.010 \mathrm{U}$ & 40.0 & 6.7 & ND \\
\hline$\left(12.0^{\prime}-12.5^{\prime}\right)$ & $0.010 \mathrm{U}$ & $0.010 \mathrm{U}$ & $0.010 \mathrm{U}$ & $0.010 \mathrm{U}$ & 30.0 & 9.0 & ND \\
\hline \multicolumn{8}{|l|}{ GW-634 } \\
\hline$\left(2.5^{\prime}-3.0^{\prime}\right)$ & $0.010 \mathrm{U}$ & $0.010 \mathrm{U}$ & $0.010 \mathrm{U}$ & $0.010 \mathrm{U}$ & $* 2420.0$ & 19.0 & ND \\
\hline$\left(4.0^{\prime}-4.5^{\prime}\right)$ & $0.010 \mathrm{U}$ & $0.010 \mathrm{U}$ & $0.010 \mathrm{U}$ & $0.018 \mathrm{~J}$ & $* 820.0$ & 17.0 & 0.018 \\
\hline$\left(6.5^{\prime}-7.0^{\prime}\right)$ & $0.010 \mathrm{U}$ & $0.010 \mathrm{U}$ & $0.010 \mathrm{U}$ & $0.023 \mathrm{~J}$ & $* 2950.0$ & 15.0 & 0.023 \\
\hline$\left(8.0^{\prime}-8.5^{\prime}\right)$ & $0.010 \mathrm{U}$ & $0.010 U$ & $0.17 \mathrm{~J}$ & $0.010 \mathrm{U}$ & $* 160.0$ & 9.0 & 0.017 \\
\hline$\left(10.0^{\prime}-10.5^{\prime}\right)$ & $0.010 \mathrm{U}$ & $0.010 \mathrm{U}$ & $0.010 \mathrm{U}$ & $0.010 \mathrm{U}$ & 30.0 & 9.1 & ND \\
\hline \multicolumn{8}{|l|}{ GW-635 } \\
\hline$\left(4.5^{\prime}-5.0^{\prime}\right)$ & $0.010 \mathrm{U}$ & $0.010 \mathrm{U}$ & $0.010 \mathrm{U}$ & $0.010 \mathrm{U}$ & $* 100.0$ & 16.0 & ND \\
\hline$\left(6.0^{\prime}-6.5^{\prime}\right)$ & $0.010 \mathrm{U}$ & $0.010 \mathrm{U}$ & $0.010 \mathrm{U}$ & $0.010 \mathrm{U}$ & 40.0 & 21.0 & ND \\
\hline$\left(8.0^{\prime}-8.5^{\prime}\right)$ & $0.010 \mathrm{U}$ & $0.010 \mathrm{U}$ & $0.010 \mathrm{U}$ & $0.010 \mathrm{U}$ & 40.0 & 19.0 & ND \\
\hline$\left(10.0^{\prime}-10.5^{\prime}\right)$ & $0.010 \mathrm{U}$ & $0.010 \mathrm{U}$ & $0.010 \mathrm{U}$ & $0.010 \mathrm{U}$ & 20.0 & 19.0 & ND \\
\hline
\end{tabular}

${ }^{1}$ Method 8240, Gas Chromatography/Mass Spectrometry (EPA, November 1986).

${ }^{2}$ Method E-418.1, Fourier Transform Infrared Spectroscopy (EPA, March 1983).

${ }^{3}$ Method 6010, Inductively Coupled Plasma Spectroscopy (EPA, November 1986).

${ }^{4}$ U-contaminant was not detected above quantitation limit during the analysis. 


\section{Table B.1 (continued)}

${ }^{5}$ NA - No analysis performed for the contaminant.

i ${ }^{6} \mathrm{~J}$ - value estimated for contaminant.

$\quad{ }^{7}$ Method 7421, Atomic Absorption Graphite Furnace (EPA, November 1986).

${ }^{8} \mathrm{ND}$ - all components of the BTX summation were below detection.

${ }^{9}$ Method 503D-503E, Infrared Spectroscopy (APMA 1985).

${ }^{10}$ Method 7420, Atomic Absorption Direct Aspiration (EPA, November 1986).

* Indicates contaminant level greater than the most stringent TDEC Closure Action Level.

Table Information Source: Corrective Action Plan for the Rust Garage Facility, Energy Systems 1992, Y/SUB/92-99928C/1.

$\underset{\sim}{\sim}$ 
Table B.2. Summary of Groundwater Analytical Data Generated from Site Investigations Conducted at the Rust Garage Facility

Analytical Results for Water Samples Collected During the Removal of Tanks 1219-U, 1222-U, and 2082-U at Building 9754-1, December 1989

\begin{tabular}{|c|c|c|c|c|c|c|c|}
\hline $\begin{array}{l}\text { Contaminant: } \\
\text { Method: } \\
\text { Units: }\end{array}$ & $\begin{array}{c}\text { Benzene } \\
624^{1} \\
\text { (ppm) }\end{array}$ & $\begin{array}{c}\text { Toluene } \\
624^{1} \\
\text { (ppm) }\end{array}$ & $\begin{array}{c}\text { Xylenes } \\
624^{1} \\
\text { (ppm) }\end{array}$ & $\begin{array}{c}\text { Ethylbenzene } \\
624^{1} \\
(\mathrm{ppm})\end{array}$ & $\begin{array}{c}\text { Total } \\
\text { Petroleum } \\
\text { Hydrocarbons } \\
\text { E-418.1 } \\
\text { (ppm) }\end{array}$ & $\begin{array}{c}\text { Lead } \\
200.7^{3} \\
(\mathrm{ppm})\end{array}$ & $\begin{array}{c}\text { Total } \\
\Sigma \text { BTEX } \\
\text { (ppm) }\end{array}$ \\
\hline $\begin{array}{l}\text { Pit Water } \\
\text { PW-1-89 } \\
\text { (West) } \\
\text { PW-2-89 } \\
\text { (Northeast) }\end{array}$ & $\begin{array}{l}0.880 \\
0.750\end{array}$ & $\begin{array}{l}11.50 \mathrm{~J}^{4} \\
10.20 \mathrm{~J}\end{array}$ & $\begin{array}{l}7.20 \\
8.40\end{array}$ & $\begin{array}{l}1.70 \\
1.80\end{array}$ & $N A^{5}$ & $\begin{array}{l}<0.02 \\
<0.02\end{array}$ & 21.28 \\
\hline \multicolumn{8}{|c|}{$\begin{array}{l}\text { Analytical Results for Water Samples Collected During the Removal of Gasoline Transfer Line at Buildings 9720-15 and 9754-1, } \\
\text { February } 1990\end{array}$} \\
\hline $\begin{array}{l}\text { Contaminant: } \\
\text { Method: } \\
\text { Units: }\end{array}$ & $\begin{array}{c}\text { Benzene } \\
624^{1} \\
(\mathrm{ppm})\end{array}$ & $\begin{array}{l}\text { Toluene } \\
624^{1} \\
\text { (ppm) }\end{array}$ & $\begin{array}{l}\text { Xylenes } \\
624^{1} \\
\text { (ppm) }\end{array}$ & $\begin{array}{c}\text { Ethylbenzene } \\
624^{1} \\
(\mathrm{ppm})\end{array}$ & $\begin{array}{c}\text { Total } \\
\text { Petroleum } \\
\text { Hydrocarbons } \\
\text { E-418.1 } \\
\text { (ppm) }\end{array}$ & $\begin{array}{c}\text { Lead } \\
239.2^{6} \\
(\mathrm{ppm})\end{array}$ & $\begin{array}{c}\text { Total } \\
\Sigma \text { BTEX } \\
\text { (ppm) }\end{array}$ \\
\hline
\end{tabular}


Table B.2 (continued)

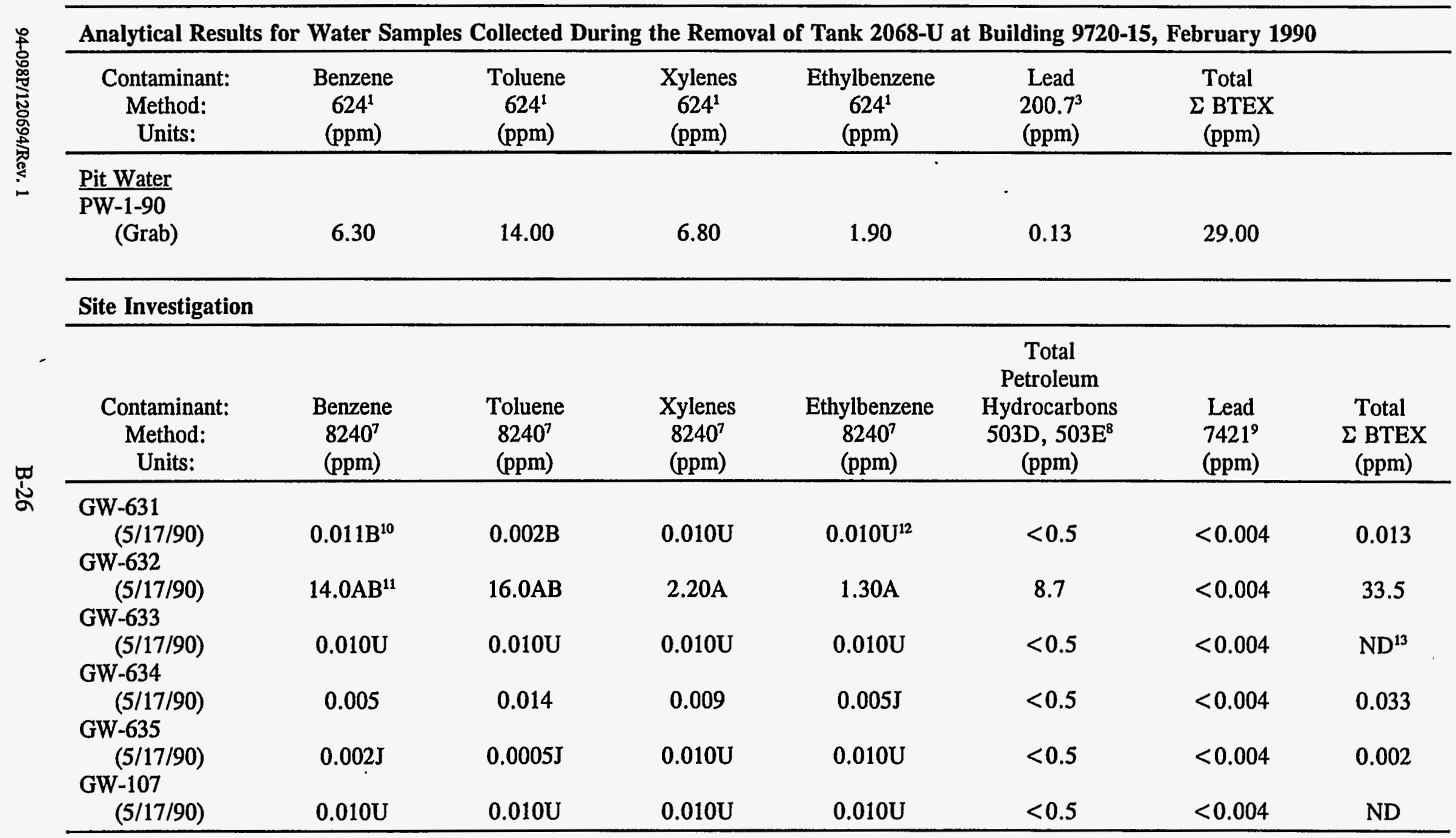


Table B.2 (continued)

\begin{tabular}{|c|c|c|c|c|c|c|}
\hline \multicolumn{7}{|c|}{1989 Groundwater Quality Assessment Report Data } \\
\hline $\begin{array}{l}\text { Contaminant: } \\
\text { Method: } \\
\text { Units: }\end{array}$ & $\begin{array}{c}\text { Benzene } \\
\text { GC/MS }{ }^{14} \\
(\mathrm{ppm})\end{array}$ & $\begin{array}{c}\text { Toluene } \\
\text { GC/MS }^{14} \\
(\mathrm{ppm})\end{array}$ & $\begin{array}{c}\text { Xylenes } \\
\text { GC/MS }{ }^{14} \\
(\mathrm{ppm})\end{array}$ & $\begin{array}{c}\text { Ethylbenzene } \\
\text { GC/MS } \\
(\mathrm{ppm})\end{array}$ & $\begin{array}{c}\text { Lead } \\
7421^{9} \\
(\mathrm{ppm}) \\
\end{array}$ & $\begin{array}{c}\text { Total } \\
\Sigma \text { BTEX } \\
\text { (ppm) }\end{array}$ \\
\hline \multicolumn{7}{|l|}{ GW-105 } \\
\hline$(2 / 22 / 89)$ & $0.005 \mathrm{U}$ & $0.005 \mathrm{U}$ & 0.011 & 0.003 & 0.018 & 0.014 \\
\hline$(5 / 17 / 89)$ & $0.005 \mathrm{U}$ & $0.005 \mathrm{U}$ & $0.005 \mathrm{U}$ & $0.005 U$ & 0.067 & ND \\
\hline$(9 / 13 / 89)$ & $0.005 \mathrm{U}$ & $0.005 \mathrm{U}$ & $0.005 \mathrm{U}$ & $0.005 \mathrm{U}$ & 0.15 & ND \\
\hline$(12 / 6 / 89)$ & $0.005 \mathrm{U}$ & $0.005 \mathrm{U}$ & $0.005 \mathrm{U}$ & $0.005 \mathrm{U}$ & 0.041 & ND \\
\hline \multicolumn{7}{|l|}{ GW-106 } \\
\hline$(2 / 21 / 89)$ & $0.005 \mathrm{U}$ & $0.005 \mathrm{U}$ & $0.005 \mathrm{U}$ & $0.005 \mathrm{U}$ & $<0.004$ & ND \\
\hline$(5 / 17 / 89)$ & $0.005 U$ & $0.005 \mathrm{U}$ & $0.005 U$ & $0.005 \mathrm{U}$ & $<0.004$ & ND \\
\hline$(9 / 12 / 89)$ & $0.005 \mathrm{U}$ & $0.005 \mathrm{U}$ & $0.005 \mathrm{U}$ & $0.005 \mathrm{U}$ & 0.0051 & ND \\
\hline$(12 / 5 / 89)$ & $0.005 \mathrm{U}$ & $0.005 \mathrm{U}$ & $0.005 \mathrm{U}$ & $0.005 \mathrm{U}$ & $<0.004$ & ND \\
\hline \multicolumn{7}{|l|}{ GW-107 } \\
\hline$(3 / 3 / 89)$ & $0.005 \mathrm{U}$ & $0.005 \mathrm{U}$ & $0.005 \mathrm{U}$ & $0.005 \mathrm{U}$ & 0.0085 & ND \\
\hline$(5 / 19 / 89)$ & $0.005 \mathrm{U}$ & $0.005 \mathrm{U}$ & $0.005 \mathrm{U}$ & $0.005 \mathrm{U}$ & $<0.004$ & ND \\
\hline$(9 / 6 / 89)$ & $0.005 \mathrm{U}$ & $0.005 \mathrm{U}$ & $0.005 \mathrm{U}$ & $0.005 \mathrm{U}$ & 0.0078 & ND \\
\hline$(12 / 6 / 89)$ & $0.005 \mathrm{U}$ & $0.005 \mathrm{U}$ & $0.005 \mathrm{U}$ & $0.005 \mathrm{U}$ & $<0.004$ & ND \\
\hline \multicolumn{7}{|l|}{ GW-108 } \\
\hline$\quad(2 / 22 / 89)$ & $0.005 U$ & $0.005 \mathrm{U}$ & 0.007 & 0.002 & $<0.004$ & 0.009 \\
\hline$(5 / 19 / 89)$ & $0.005 U$ & $0.005 \mathrm{U}$ & $0.005 \mathrm{U}$ & $0.005 U$ & $<0.004$ & ND \\
\hline$(9 / 6 / 89)$ & $0.050 \mathrm{U}$ & $0.050 \mathrm{U}$ & $0.050 \mathrm{U}$ & $0.050 \mathrm{U}$ & $<0.004$ & ND \\
\hline$(12 / 6 / 89)$ & $0.050 \mathrm{U}$ & $0.050 \mathrm{U}$ & $0.050 \mathrm{U}$ & $0.050 \mathrm{U}$ & $<0.004$ & ND \\
\hline \multicolumn{7}{|l|}{ GW-109 } \\
\hline$(3 / 6 / 89)$ & $0.0005 \mathrm{U}$ & 0.002 & $0.005 \mathrm{U}$ & $0.005 \mathrm{U}$ & 0.016 & 0.002 \\
\hline$(5 / 17 / 89)$ & $0.005 \mathrm{U}$ & 0.002 & $0.005 \mathrm{U}$ & $0.005 \mathrm{U}$ & 0.022 & 0.002 \\
\hline$(9 / 11 / 89)$ & $0.050 \mathrm{U}$ & $0.050 \mathrm{U}$ & $0.050 \mathrm{U}$ & $0.050 \mathrm{U}$ & $<0.004$ & ND \\
\hline$(12 / 1 / 89)$ & $0.050 \mathrm{U}$ & $0.050 \mathrm{U}$ & $0.050 \mathrm{U}$ & $0.050 \mathrm{U}$ & 0.023 & ND \\
\hline
\end{tabular}


Table B.2 (continued)

\begin{tabular}{|c|c|c|c|c|c|c|}
\hline \multicolumn{7}{|c|}{1989 Groundwater Quality Assessment Report Data (continued) } \\
\hline $\begin{array}{l}\text { Contaminant: } \\
\text { Method: } \\
\text { Units: }\end{array}$ & $\begin{array}{c}\text { Benzene } \\
\mathrm{GC}^{-\mathrm{MS}^{14}} \\
(\mathrm{ppm})\end{array}$ & $\begin{array}{c}\text { Toluene } \\
\text { GC/MS }{ }^{14} \\
(\mathrm{ppm})\end{array}$ & $\begin{array}{c}\text { Xylenes } \\
\text { GC/MS }^{14} \\
(\mathrm{ppm})\end{array}$ & $\begin{array}{c}\text { Ethylbenzene } \\
\text { GC/MS }{ }^{14} \\
(\mathrm{ppm})\end{array}$ & $\begin{array}{l}\text { Lead } \\
7421^{9} \\
(\mathrm{ppm})\end{array}$ & $\begin{array}{c}\text { Total } \\
\Sigma \text { BTEX } \\
(\mathrm{ppm})\end{array}$ \\
\hline \multicolumn{7}{|l|}{ GW-270 } \\
\hline$(2 / 21 / 89)$ & $0.005 \mathrm{U}$ & $0.005 \mathrm{U}$ & $0.005 \mathrm{U}$ & $0.005 \mathrm{U}$ & 0.0089 & ND \\
\hline$(5 / 15 / 89)$ & $0.005 \mathrm{U}$ & $0.005 \mathrm{U}$ & $0.005 \mathrm{U}$ & $0.005 U$ & 0.0052 & ND \\
\hline$(9 / 13 / 89)$ & $0.005 \mathrm{U}$ & $0.005 \mathrm{U}$ & $0.005 \mathrm{U}$ & $0.005 \mathrm{U}$ & $<0.004$ & ND \\
\hline$(12 / 6 / 89)$ & $0.005 \mathrm{U}$ & $0.005 \mathrm{U}$ & $0.005 \mathrm{U}$ & $0.005 \mathrm{U}$ & 0.0041 & ND \\
\hline \multicolumn{7}{|c|}{1990 Groundwater Quality Assessment Report Data } \\
\hline $\begin{array}{l}\text { Contaminant: } \\
\text { Method: } \\
\text { Units: }\end{array}$ & $\begin{array}{c}\text { Benzene } \\
\mathrm{GC} / \mathrm{MS}^{14} \\
(\mathrm{ppm})\end{array}$ & $\begin{array}{l}\text { Toluene } \\
\text { GC/MS } \\
\text { (ppm) }\end{array}$ & $\begin{array}{c}\text { Xylenes } \\
\text { GC/MS }^{14} \\
\text { (ppm) }\end{array}$ & $\begin{array}{c}\text { Ethylbenzene } \\
\mathrm{GC} / \mathrm{MS}^{14} \\
(\mathrm{ppm})\end{array}$ & $\begin{array}{l}\text { Lead } \\
7421^{9} \\
(\mathrm{ppm})\end{array}$ & $\begin{array}{c}\text { Total } \\
\Sigma \text { BTEX } \\
\text { (ppm) }\end{array}$ \\
\hline $\begin{array}{l}\text { GW-105 } \\
(1 / 19 / 90) \\
G W-106\end{array}$ & $0.005 \mathrm{U}$ & $0.005 \mathrm{U}$ & $0.005 \mathrm{U}$ & $0.005 \mathrm{U}$ & 0.17 & ND \\
\hline $\begin{array}{l}(1 / 16 / 90) \\
\text { GW-107 }\end{array}$ & $0.005 \mathrm{U}$ & $0.005 \mathrm{U}$ & $0.005 U$ & $0.005 \mathrm{U}$ & $<0.004$ & ND \\
\hline $\begin{array}{l}(1 / 19 / 90) \\
\text { GW-108 }\end{array}$ & $0.005 \mathrm{U}$ & $0.005 \mathrm{U}$ & $0.005 \mathrm{U}$ & $0.005 \mathrm{U}$ & 0.5 & ND \\
\hline $\begin{array}{l}(1 / 18 / 90) \\
\text { GW-109 }\end{array}$ & $0.005 \mathrm{U}$ & $0.005 \mathrm{U}$ & $0.005 \mathrm{U}$ & $0.005 \mathrm{U}$ & 2.28 & ND \\
\hline $\begin{array}{c}(1 / 18 / 90) \\
G W-270\end{array}$ & $0.050 \mathrm{U}$ & $0.050 \mathrm{U}$ & $0.050 \mathrm{U}$ & $0.050 \mathrm{U}$ & 1.73 & ND \\
\hline$(1 / 19 / 90)$ & $0.005 \mathrm{U}$ & $0.005 \mathrm{U}$ & $0.005 \mathrm{U}$ & $0.005 \mathrm{U}$ & 0.0046 & ND \\
\hline
\end{tabular}


Table B.2 (continued)

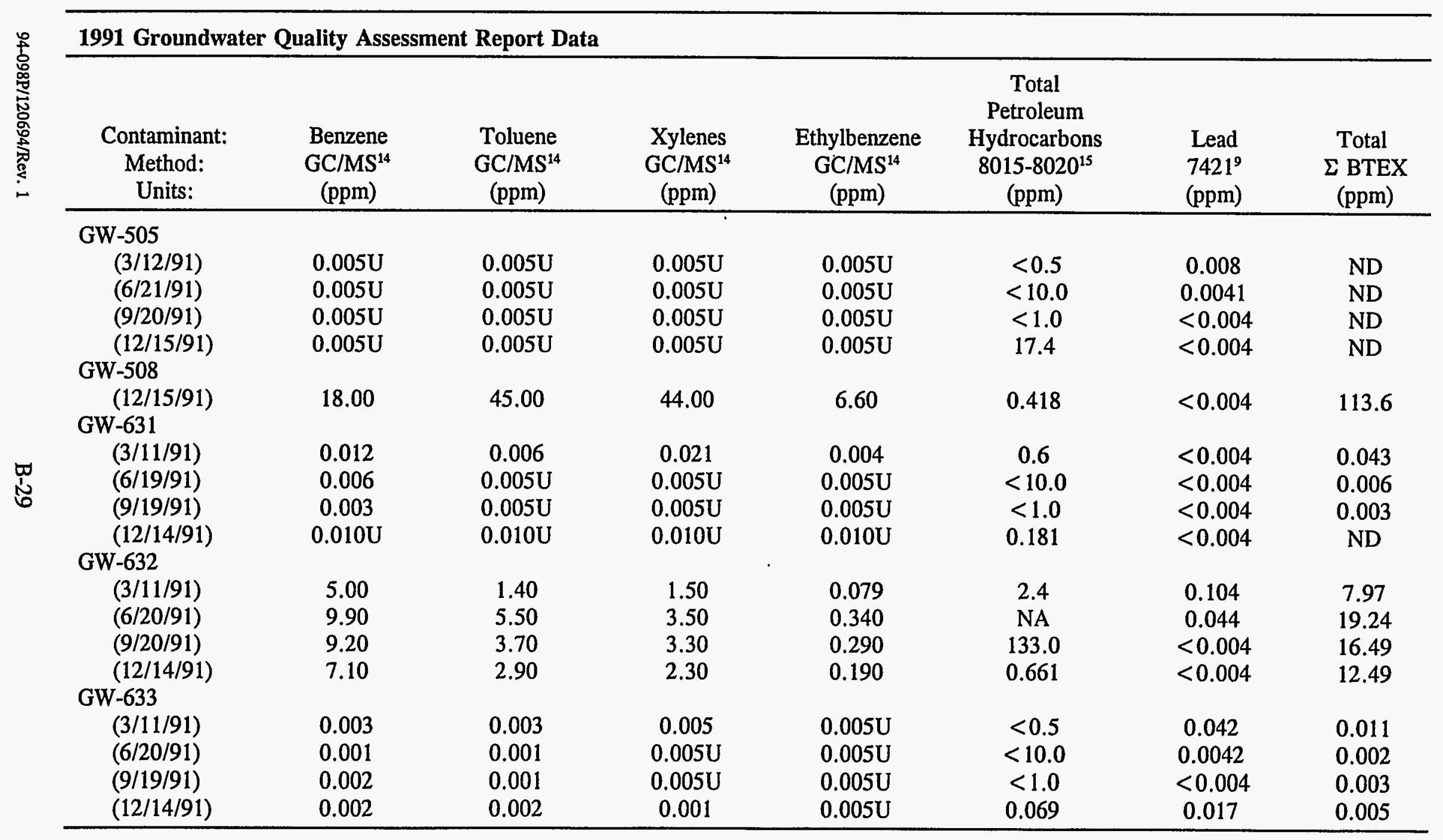


Table B.2 (continued)

\begin{tabular}{|c|c|c|c|c|c|c|c|}
\hline \multicolumn{8}{|c|}{1991 Groundwater Quality Assessment Report Data (continued) } \\
\hline $\begin{array}{l}\text { Contaminant: } \\
\text { Method: } \\
\text { Units: }\end{array}$ & $\begin{array}{c}\text { Benzene } \\
\mathrm{GC}^{1} \mathrm{MS}^{14} \\
(\mathrm{ppm})\end{array}$ & $\begin{array}{c}\text { Toluene } \\
{\mathrm{GC} / \mathrm{MS}^{14}}^{(\mathrm{ppm})}\end{array}$ & $\begin{array}{c}\text { Xylenes } \\
\mathrm{GC}^{\prime} \mathrm{MS}^{14} \\
(\mathrm{ppm})\end{array}$ & $\begin{array}{c}\text { Ethylbenzene } \\
\text { GC/MS } \\
\text { (ppm) }\end{array}$ & $\begin{array}{c}\text { Total } \\
\text { Petroleum } \\
\text { Hydrocarbons } \\
8015-8020^{15} \\
(\mathrm{ppm})\end{array}$ & $\begin{array}{l}\text { Lead } \\
7421^{9} \\
(\mathrm{ppm})\end{array}$ & $\begin{array}{c}\text { Total } \\
\Sigma \text { BTEX } \\
\text { (ppm) }\end{array}$ \\
\hline $\begin{array}{c}\text { GW-634 } \\
(3 / 9 / 91) \\
(6 / 19 / 91) \\
(9 / 20 / 91) \\
(12 / 14 / 91) \\
\end{array}$ & $\begin{array}{c}0.490 \\
1.40 \\
0.970 \\
0.880 \\
\end{array}$ & $\begin{array}{l}1.10 \\
3.30 \\
2.20 \\
2.40 \\
\end{array}$ & $\begin{array}{l}1.90 \\
5.40 \\
4.30 \\
4.10 \\
\end{array}$ & $\begin{array}{c}0.320 \\
1.10 \\
0.990 \\
0.920\end{array}$ & $\begin{array}{c}4.2 \\
43.0 \\
188.0 \\
1.31 \\
\end{array}$ & $\begin{array}{l}<0.004 \\
<0.004 \\
<0.004 \\
<0.004 \\
\end{array}$ & $\begin{array}{c}3.81 \\
11.20 \\
8.46 \\
8.30\end{array}$ \\
\hline \multicolumn{8}{|c|}{1992 Groundwater Quality Assessment Report Data } \\
\hline $\begin{array}{l}\text { Contaminant: } \\
\text { Method: } \\
\text { Units: }\end{array}$ & $\begin{array}{c}\text { Benzene } \\
\text { GC/MS }{ }^{14} \\
(\mathrm{ppm})\end{array}$ & $\begin{array}{c}\text { Toluene } \\
\mathrm{GC}^{\prime} / \mathrm{MS}^{14} \\
(\mathrm{ppm})\end{array}$ & $\begin{array}{c}\text { Xylenes } \\
\text { GC/MS }{ }^{14} \\
\text { (ppm) }\end{array}$ & $\begin{array}{c}\text { Ethylbenzene } \\
\text { GC/MS }{ }^{14} \\
(\mathrm{ppm})\end{array}$ & $\begin{array}{c}\text { TPH-DRO } \\
\text { SW846 8015 } \\
\text { (ppm) }\end{array}$ & $\begin{array}{c}\text { TPH-GRO } \\
\text { SW-846 8020 } \\
(\mathrm{ppm})\end{array}$ & $\begin{array}{c}\text { Total TPH } \\
\Sigma \mathrm{TPH}^{19} \\
(\mathrm{ppm}) \\
\end{array}$ \\
\hline \multicolumn{8}{|l|}{ GW-505 } \\
\hline $\begin{array}{l}\text { 1st quarter } \\
\text { 2nd quarter } \\
\text { 3rd quarter } \\
\text { 4th quarter }\end{array}$ & $\begin{array}{l}0.005 \mathrm{U} \\
0.005 \mathrm{U} \\
0.005 \mathrm{U} \\
0.005 \mathrm{U}\end{array}$ & $\begin{array}{l}0.005 \mathrm{U} \\
0.005 \mathrm{U} \\
0.005 \mathrm{U} \\
0.005 \mathrm{U}\end{array}$ & $\begin{array}{l}0.005 \mathrm{U} \\
0.005 \mathrm{U} \\
0.005 \mathrm{U} \\
0.005 \mathrm{U}\end{array}$ & $\begin{array}{l}0.005 \mathrm{U} \\
0.005 \mathrm{U} \\
0.005 \mathrm{U} \\
0.005 \mathrm{U}\end{array}$ & $\begin{array}{l}0.002 \\
0.11 \\
0.09 \\
0.05\end{array}$ & $\begin{array}{c}\text { NA } \\
0.0011 \mathrm{~J} \\
<0.005 \\
<0.005\end{array}$ & $\begin{array}{c}\overline{-1111 \mathrm{~J}} \\
0.095 \\
<0.055\end{array}$ \\
\hline
\end{tabular}


Table B.2 (continued)

\begin{tabular}{|c|c|c|c|c|c|c|c|}
\hline 1992 Groundwa & uality Asse & t Report D & ntinued) & & & & \\
\hline $\begin{array}{c}\text { Contaminant: } \\
\text { Method: } \\
\text { Units: } \\
\end{array}$ & $\begin{array}{c}\text { Benzene } \\
\mathrm{GC}^{\prime} \mathrm{MS}^{14} \\
(\mathrm{ppm})\end{array}$ & $\begin{array}{c}\text { Toluene } \\
\text { GC/MS }^{14} \\
(\mathrm{ppm})\end{array}$ & $\begin{array}{c}\text { Xylenes } \\
\mathrm{GC} / \mathrm{MS}^{14} \\
(\mathrm{ppm}) \\
\end{array}$ & $\begin{array}{c}\text { Ethylbenzene } \\
\text { GC/MS }{ }^{14} \\
(\mathrm{ppm})\end{array}$ & $\begin{array}{c}\text { TPH-DRO } \\
\text { SW846 8015 } \\
\text { (ppm) }\end{array}$ & $\begin{array}{c}\text { TPH-GRO } \\
\text { SW-846 8020 } \\
(\mathrm{ppm})\end{array}$ & $\begin{array}{c}\text { Total TPH } \\
\Sigma \text { TPH }^{19} \\
\text { (ppm) }\end{array}$ \\
\hline \multicolumn{8}{|l|}{ GW-508 } \\
\hline 1st quarter & NA & NA & NA & NA & NA & NA & NA \\
\hline 2nd quarter & NA & NA & NA & NA & $\mathrm{NA}$ & $\mathrm{NA}$ & $\mathrm{NA}$ \\
\hline 3rd quarter & 9.1 & 28 & 22 & 3.4 & 56.3 & 59.600 & 115.9 \\
\hline 4th quarter & 8.8 & 34 & 17 & 3.0 & 64.5 & 181.000 & 245.5 \\
\hline \multicolumn{8}{|l|}{ GW-631 } \\
\hline 1st quarter & $0.010 \mathrm{U}$ & $0.005 \mathrm{U}$ & $0.005 \mathrm{U}$ & $0.005 \mathrm{U}$ & 0.03 & NA & - \\
\hline 2nd quarter & $0.010 \mathrm{U}$ & $0.005 \mathrm{U}$ & $0.005 \mathrm{U}$ & $0.005 \mathrm{U}$ & 0.19 & 0.0211 & 0.02111 \\
\hline 3rd quarter & $0.010 \mathrm{U}$ & $0.005 \mathrm{U}$ & $0.005 \mathrm{U}$ & $0.005 \mathrm{U}$ & 0.24 & 0.0075 & 0.2475 \\
\hline $\begin{array}{l}\text { 4th quarter } \\
\text { GW-632 }\end{array}$ & $0.010 \mathrm{U}$ & $0.005 \mathrm{U}$ & $0.005 \mathrm{U}$ & \multicolumn{3}{|c|}{ GW-632 } & 0.193 \\
\hline 1st quarter & 6.9 & 1.9 & 1.6 & 0.14 & 0.115 & NA & - \\
\hline 2nd quarter & 5.8 & 1.5 & 1.3 & $0.3 \mathrm{U}$ & 1.12 & 2.592 & 3.7120 \\
\hline 3rd quarter & 8.6 & 2.5 & 2.8 & 0.18 & 3.21 & 36.700 & 39.91 \\
\hline 4th quarter & 9.4 & 0.90 & 1.7 & 0.063 & 4.25 & 13.190 & 17.44 \\
\hline \multicolumn{8}{|l|}{ GW-633 } \\
\hline 1st quarter & $0.010 \mathrm{U}$ & 0.003 & $0.05 \mathrm{U}$ & $0.05 \mathrm{U}$ & 0.003 & $\mathrm{NA}$ & - \\
\hline 2nd quarter & $0.010 \mathrm{U}$ & 0.003 & $0.05 \mathrm{U}$ & $0.05 \mathrm{U}$ & 0.12 & 0.0175 & 0.1375 \\
\hline 3rd quarter & $0.010 \mathrm{U}$ & 0.003 & $0.05 \mathrm{U}$ & $0.05 \mathrm{U}$ & 0.11 & 0.0054 & 0.1154 \\
\hline \multicolumn{8}{|l|}{ GW-634 } \\
\hline 1st quarter & 0.79 & 2 & 4.3 & 0.940 & 0.26 & NA & - \\
\hline 2nd quarter & .0 .75 & 1.7 & 4.2 & 0.910 & 6.1 & 5.653 & 11.753 \\
\hline 3rd quarter & 0.73 & 1.5 & 4.6 & 0.960 & 7 & 10.976 & 17.976 \\
\hline 4th quarter & 0.47 & 0.95 & 3.8 & 0.920 & 7.23 & 11.649 & 13.879 \\
\hline
\end{tabular}


Table B.2 (continued)

\begin{tabular}{|c|c|c|c|c|c|c|c|}
\hline \multicolumn{8}{|c|}{1993 UST Monitoring Well Sampling } \\
\hline $\begin{array}{l}\text { Contaminant: } \\
\text { Method: } \\
\text { Units: }\end{array}$ & $\begin{array}{c}\text { Benzene } \\
\text { SW846 8020 } \\
\text { (ppm) }\end{array}$ & $\begin{array}{c}\text { Toluene } \\
\text { SW846 8020 } \\
\text { (ppm) }\end{array}$ & $\begin{array}{c}\text { Xylenes } \\
\text { SW846 802017 } \\
\text { (ppm) }\end{array}$ & $\begin{array}{c}\text { Ethylbenzene } \\
\text { SW846 802017 } \\
\text { (ppm) }\end{array}$ & $\begin{array}{c}\text { TPH-DRO } \\
\text { SW846 } 8015^{18} \\
(p p m)\end{array}$ & $\begin{array}{c}\text { TPH-GRO } \\
\text { SW-846 8020 } \\
\text { (ppm) }\end{array}$ & $\begin{array}{c}\text { Total TPH } \\
\Sigma \text { TPH }^{19} \\
(\mathrm{ppm})\end{array}$ \\
\hline \multicolumn{8}{|l|}{ GW-508 } \\
\hline 1st quarter & 9.200 & 28.00 & 11.1 & NA & 24.06 & 77.6 & 101.66 \\
\hline 2nd quarter & 9.036 & 30.554 & 16.080 & NA & 1422.9 & 89.0 & 1511.90 \\
\hline 3rd quarter & 6.346 & 8.064 & 12.919 & NA & 88.08 & 42.9 & 130.98 \\
\hline 4th quarter & 0.1529 & $0.002^{16}$ & 1.271 & NA & 21.49 & 27.8 & 49.29 \\
\hline \multicolumn{8}{|l|}{ GW-631 } \\
\hline 1st quarter & 0.0017 & $<0.005$ & $<0.005$ & NA & 0.003 & 0.0282 & 0.0312 \\
\hline 2nd quarter & $<0.005$ & $<0.005$ & $<0.005$ & NA & $<0.1$ & 0.0155 & 0.1155 \\
\hline 3rd quarter & $<0.005$ & $<0.005$ & $<0.005$ & NA & 0 & 0.0078 & 0.0078 \\
\hline \multicolumn{8}{|l|}{ GW-632 } \\
\hline 1st quarter & 10.440 & 3.865 & 1.557 & NA & 2.098 & 20.530 & 22.628 \\
\hline 2nd quarter & 6.924 & 5.518 & 3.746 & NA & 3.3 & 25.582 & 28.882 \\
\hline 3rd quarter & 4.329 & 0.580 & 2.891 & $\mathrm{NA}$ & 2.61 & 15.420 & 18.030 \\
\hline 4th quarter & 0.4529 & 0.2614 & 0.165 & NA & 4.2 & 4.461 & 8.661 \\
\hline \multicolumn{8}{|l|}{ GW-634 } \\
\hline 1st quarter & 0.425 & 0.251 & 2.083 & NA & 6.032 & 105.016 & 111.048 \\
\hline 2nd quarter & 0.018 & 0.570 & 1.604 & NA & 4.48 & 10.158 & 14.638 \\
\hline 3rd quarter & 0.309 & 0.3215 & 1.2656 & NA & 2.48 & 8.031 & 10.511 \\
\hline 4th quarter & 0.0568 & 0.597 & 0.1096 & NA & 5.16 & 3.933 & 9.093 \\
\hline
\end{tabular}


Table B.2 (continued)

\begin{tabular}{|c|c|c|c|c|c|c|c|}
\hline \multicolumn{8}{|c|}{ April 1994 Comprehensive Monitoring } \\
\hline $\begin{array}{l}\text { Contaminant: } \\
\text { Method: } \\
\text { Units: }\end{array}$ & $\begin{array}{c}\text { Benzene } \\
\text { SW846 802017 } \\
(\mathrm{ppm})\end{array}$ & $\begin{array}{c}\text { Toluene } \\
\text { SW846 802017 } \\
\text { (ppm) }\end{array}$ & $\begin{array}{c}\text { Xylenes } \\
\text { SW846 8020 } \\
(\mathrm{ppm})\end{array}$ & $\begin{array}{c}\text { Ethylbenzene } \\
\text { SW846 802017 } \\
\text { (ppm) }\end{array}$ & $\begin{array}{c}\text { TPH-DRO } \\
\text { SW846 8015 } \\
\text { (ppm) }\end{array}$ & $\begin{array}{c}\text { TPH-GRO } \\
\text { SW-846 802017 } \\
\text { (ppm) }\end{array}$ & $\begin{array}{c}\text { Total TPH } \\
\begin{array}{c}\Sigma \mathrm{TPH} \\
(\mathrm{ppm})\end{array}\end{array}$ \\
\hline GW-508 & 5.6 & 26.000 & 15.000 & 2.200 & 60.000 & 69.000 & 129.000 \\
\hline GW-631 & $0.010 \mathrm{U}$ & $0.010 \mathrm{U}$ & $0.010 \mathrm{U}$ & $0.010 \mathrm{U}$ & $0.057 \mathrm{~J}$ & $0.010 \mathrm{U}$ & $0.557 \mathrm{~J}$ \\
\hline GW-632 & 9.200 & 2.600 & 3.200 & $2.000 \mathrm{U}$ & 14.000 & 27.000 & 41.000 \\
\hline GW-634 & 0.260 & 0.340 & 1.900 & 0.500 & 11.000 & 8.6 & 19.600 \\
\hline
\end{tabular}

${ }^{1}$ Method 624, Purge and Trap Gas Chromatography/Mass Spectrometry (40 CFR Part 136).

${ }^{2}$ Method E-418.1, Fourier Transform Infrared Spectroscopy (EPA, March 1983).

${ }^{3}$ Method 200.7 Inductively Coupled Plasma Spectroscopy (EPA, March 1983).

${ }^{4} \mathrm{~J}$ - Value estimated for contaminant.

${ }^{5} \mathrm{NA}$ - No analysis performed for contaminant.

$\square \quad{ }^{6}$ Method 239.2, Atomic Absorption Graphite Furnace (EPA, March 1983).

山 ${ }^{7}$ Method 8240, Gas Chromatography/Mass Spectroscopy (EPA, November 1986).

${ }^{8}$ Method 5030, 503E, Infrared Spectroscopy (APHA, 1985).

9 Method 7421, Atomic Absorption Graphite Furnace (EPA, November 1986).

${ }^{10} \mathrm{~B}$ - Exceeded initial calibration range.

"A - Required secondary dilution.

${ }^{12} \mathrm{U}$ - Contaminant was not detected above quantitation limit during the analysis.

${ }^{13}$ ND - All components of the BTX or TPH summation were below detection.

${ }^{14}$ GC/MS, Gas Chromatography/Mass Spectrometry, Modified Contract Laboratory Program Protocol (EPA, February 1988).

${ }^{15}$ Method 8015-8020, Gas Chromatography, Modified California Method (EPA, November 1986).

${ }^{16}$ Interference Peak.

${ }^{17}$ Method SW846 8020 Gas Chromatography/Mass Spectrometry (EPA, September 1986).

${ }^{18}$ Method SW846 8015 Gas Chromatography/Mass Spectrometry (EPA, September 1986).

19 Summation of TPH-DRO and TPH-GRO values.

Table Information Sources:

- Corrective Action Plan for the Rust Garage Facility, Energy Systems, 1992, Y/SUB/92-99928C/1.

- 1993 Upper East Fork Hydrogeologic Regime Groundwater Quality Report, Energy Systems, 1994, Y/SUB/94-EAQ10C/2/P1.

- Comprehensive Monitoring Report for the Rust Garage Facility, Energy Systems 1994, Y/SUB/94-99069C/Y1517. 
Table B.3. Parameters Describing Chemical Characteristics of Petroleum Constituents Present at the Rust Garage Facility

\begin{tabular}{|c|c|c|c|c|c|c|}
\hline \multirow[b]{2}{*}{ Chemical } & \multicolumn{2}{|c|}{ Mobility } & \multicolumn{2}{|c|}{ Persistence } & \multicolumn{2}{|c|}{$\cdot \quad$ Toxicity } \\
\hline & $\begin{array}{l}\text { Water solubility } \\
(\mathrm{mg} / \mathrm{L})^{1}\end{array}$ & $\begin{array}{c}\text { Log Octanol-Water } \\
\text { Partition } \\
\text { Coefficient }^{2}\end{array}$ & $\begin{array}{c}\text { Biodegradation } \\
\text { Coefficient } \\
\left(\text { Day }^{-1}\right)^{3}\end{array}$ & $\begin{array}{l}\text { Henry's Law } \\
\text { Constant } \\
\left(\mathrm{atm}-\mathrm{m}^{3} / \mathrm{mol}\right)^{4}\end{array}$ & $\begin{array}{l}\text { Oral Cancer } \\
\text { Slope Factor } \\
\left(\mathrm{mg} / \mathrm{kg}^{\left.- \text {day }^{-1}\right)^{5}}\right.\end{array}$ & $\begin{array}{c}\text { Oral Reference } \\
\text { Dose } \\
\text { (mg/kg-day) }{ }^{6}\end{array}$ \\
\hline $\begin{array}{l}\text { Reference } \\
\text { chemical - } \\
\text { Benzo(a)pyrene }\end{array}$ & $1.2 \mathrm{E}-03$ & $6.0 \mathrm{E}+00$ & 2.5E-04 & $1.5 \mathrm{E}-06$ & $7.3 E+00$ & NT \\
\hline Benzene & $1.8 E+03$ & $2.1 E+00$ & $9.50 \mathrm{E}-04$ & $5.6 \mathrm{E}-03$ & 2.9E-02 & NT \\
\hline Toluene & $5.4 \mathrm{E}+02$ & $2.7 \mathrm{E}+00$ & $3.30 \mathrm{E}-03$ & $6.4 \mathrm{E}-03$ & NC & $1.0 \mathrm{E}-01$ \\
\hline Ethylbenzene & $1.5 \mathrm{E}+02$ & $3.2 \mathrm{E}+00$ & $3.04 \mathrm{E}-03$ & $6.4 \mathrm{E}-03$ & $\mathrm{NC}$ & $2.0 \mathrm{E}-01$ \\
\hline Xylenes & $1.9 \mathrm{E}+02$ & $3.0 \mathrm{E}+00$ & $1.90 \mathrm{E}-03$ & 7.0E-03 & $\mathrm{NC}$ & $2.0 \mathrm{E}+00$ \\
\hline $\begin{array}{l}\text { Methyl-tert-butyl } \\
\text { ether (MBTE) }\end{array}$ & $4.8 \mathrm{E}+04^{2}$ & $\mathrm{NA}^{7}$ & NA & NA & NC & $\mathrm{NT}^{8}$ \\
\hline TPH & $\mathrm{NDA}^{9}$ & NDA & NDA & NDA & NDA & NDA \\
\hline Di-isopropyl ether & $9.0 \mathrm{E}+0.3^{2}$ & NA & NA & $\mathrm{NA}$ & $\mathrm{NC}$ & NT \\
\hline
\end{tabular}

1 From EPA 1986.

2 From the USEPA Treatability Database (1991). A lower octanol-water partition coefficient indicates a tendency to partition from solids to liquids.

${ }^{3}$ Biological biodegradation coefficient is estimated using half-lives from Howard et al., 1991 and the formula $\lambda_{c}=\ln (2) / T_{12}$ from Cember (1983). A smaller biodegradation coefficient suggests that the chemical will persist in the soil longer.

${ }^{4}$ From EPA 1986. Henry's Law Constant describes a chemical's tendency to partition or volatilize into the air. A high Henry's Law Constant suggests a chemical has a high tendency to volatilize.

5 From IRIS 1993. The oral cancer slope factor describes the slope of the dose-response curve for a carcinogen. The greater the slope, the more potent the carcinogen. "NC" denoted chemicals that are not carcinogens.

6 From IRIS 1993. The oral reference dose is the dose below which no toxic effects are likely to occur. Toxic effects are wide ranging in type and include such effects as eye irritation, kidney disease, blood disorders, etc. The lower the oral reference dose, the more potent the toxicant. As a point of reference, a relatively potent toxicant, arsenic, has an oral reference dose of 3.0E-04 . "NT" denotes chemicals that are not regulated as toxicants.

7 Data not readily available for this compound.

${ }^{8}$ MBTE displays toxic effects via the inhalation route but not via oral ingestion.

9 TPH is a complex mixture that varies in chemical make-up, depending on several factors including the parent fuel product, additives, etc. Chemical characteristics are dependent on the site-specific TPH mixture and cannot be obtained from the literature. 


\begin{tabular}{|c|c|c|}
\hline Parameters & Range of values & Comment/Reference \\
\hline Hydraulic conductivity, $\mathrm{Ks}$ (ft/day) & 0.028 to 2.83 & Based on slug test results \\
\hline Hydraulic gradient, i (ft/ft) & 0.017 & Based on potentiometric surface \\
\hline Effective porosity, $n_{c}$ & 0.04 & Default values at Oak Ridge Reservation \\
\hline Seepage velocity, Vs (ft/day) & 0.012 to 1.2 & Calculated, $\mathrm{Vs}=\mathrm{Ks} . \mathrm{i} / \mathrm{n}_{\mathrm{c}}$ \\
\hline Dispersion coefficient, $D x\left(\mathrm{ft}^{2} /\right.$ day $)$ & 1.2 to 120 & $\begin{array}{l}\text { Calculated by, } D x=a_{1} \cdot V s+D^{*} \\
\text { where, } a_{1}=\text { longitudinal dispersivity, } D^{*}=\text { molecular dispersion } \\
\text { coefficient }\end{array}$ \\
\hline Retardation factor $\left(\mathrm{R}_{\mathrm{f}}\right)$ & 1.3 to 4.02 & $\begin{array}{l}\text { Calculated by, } \mathrm{R}_{\mathrm{f}}=1+\mathrm{K}_{\mathrm{d}} \cdot \rho_{\mathrm{b}} / \ominus \\
\text { Where, } \rho_{\mathrm{b}}=\text { bulk density, } \ominus=\text { soil moisture content, and } \\
\mathrm{K}_{\mathrm{d}}=\mathrm{Koc} . \mathrm{f}_{\mathrm{oc}}\end{array}$ \\
\hline Biodegradation rate $\left(\right.$ day $\left.^{-1}\right)$ & 0.0062 to 0.00096 & Howard et al. 1991 \\
\hline Source depletion time (years) & 100 & Assumed conservative value \\
\hline Source depletion rate & 0.000027 & Based on 100 years source depletion \\
\hline
\end{tabular}




\section{Provide the Hydrogeologic Characteristics of the Petroleum Site and the Surrounding Land}

\section{C.1 Petroleum Site \\ C.1.a The soil permeability as required in Section $E$ of the Environmental Assessment Guidelines (EAG)}

Determination of soil permeability at the Rust Garage Facility is based on hydraulic conductivity values derived from slug testing data obtained from monitoring wells GW-631 through GW-635 during the Site Investigation conducted at the facility in May 1990.

All five wells tested are within a $125 \mathrm{ft}$ radius of the facility and were constructed in a similar manner. To construct each well, a 10.5 inch diameter borehole was advanced to approximately $15 \mathrm{ft}$ below the ground surface (16 ft for GW-631). Each well was constructed of 4.5-inch diameter PVC screen and casing. A $10-\mathrm{ft}$ screen ( 0.01 inch slotted) was placed in the approximate interval of 5 to $15 \mathrm{ft}$ below the ground surface and packed with $45 / 55$ fraction filter sand. With minor exceptions, the stratigraphy encountered in all five borings consists of a near surface fill material, an intermediate clay layer, and bedrock at depth. Lithologic logs, well construction diagrams, and slug test data records for each of the monitoring wells are presented in Appendix G of the Corrective Action Plan for the Rust Garage Facility (Energy Systems 1992, Y/SUB/92-99928C/1).

The slug tests were conducted by measuring the initial water level in each monitoring well, filling the annulus with water to the top of the casing, and monitoring the fall off. Each well was tested once per day on three consecutive days; however, the permeability of the soils at the Rust Garage Facility is such that the water level did not return to its static position prior to the start of the second and third day tests. Due to this condition, the second and third day test data for each well are invalid and only the first day test data could be used for analysis. The mechanics for the slug tests are taken from Dawson and Istok (1991). The method used for analysis is based on Brouwer and Rice (1976). In this method, a volume of water is instantaneously introduced into a well at time $(t)=0$. The fall off (or flow, $Q$ ) of the water level at $t>0$ is related to the hydraulic conductivity of the aquifer. Corrections are made for partially penetrating wells and the large diameter of the packed interval in relation to casing size.

The hydraulic conductivities (equated to soil permeabilities) calculated for GW-631, GW-632, and GW-633 were all found to fall in the range of $10^{-5} \mathrm{~cm} / \mathrm{sec}$. Values calculated for GW-634 and GW-635 were found to fall in the range of $10^{-4} \mathrm{~cm} / \mathrm{sec}$ and $10^{-3} \mathrm{~cm} / \mathrm{sec}$, respectively. Overall it can be inferred that the average hydraulic conductivities of this area are in the $10^{-4} \mathrm{~cm} / \mathrm{sec}$ range.

\section{C.1.b and c Groundwater recharge area and rate}

The Rust Garage Facility is located within the Upper East Fork Poplar Creek Hydrogeologic Regime (East Fork Regime) (Figure C.1). This hydrogeologic regime is located in the eastern end of Bear Creek Valley (BCV) and encompasses the Y-12 Plant complex. The primary recharge areas for the groundwater system in the East Fork Regime are Pine Ridge, located along the northern side of BCV, and Chestnut Ridge, located along the southern side of BCV. Pine Ridge and the northern portions of BCV are underlain by formations of the Conasuaga Group (excluding the Maynardville Limestone) and the Rome Formation, which, in part, comprise the Oak Ridge Reservation (ORR) Aquitards. Chestnut Ridge and the southern portion of BCV are underlain by the Knox Group and the underlying 
Maynardville Limestone of the Conasauga Group. The Knox Group and the Maynardville Limestone comprise the Knox Aquifer. Annual recharge is greater for the Knox Aquifer (about 2.6 inches) than for the ORR Aquitards (about 0.8 inches), and it is possible that a portion of the recharge to each unit results from delayed unsaturated flow (Groundwater Quality Assessment for the Upper East Fork Poplar Creek Hydrogeologic Regime at the Y-12 Plant, 1993, Y/SUB/93-YP507C/2/P1). Recharge to the aquifer below the Rust Garage Facility occurs to a lesser extent by direct precipitation and infiltration at the site. Additional information regarding the East Fork Regime groundwater system is presented in Section C.2.c of this document.

\section{C.1.d Hydrology (groundwater flow gradient, direction, and the occurrence of main aquifers or water bearing zones)}

The Rust Garage Facility is located on soil and residuum above the Nolichucky Shale Formation, in which bedrock joints and fractures have been shown to exhibit strong control on groundwater flow direction. Major joint sets throughout BCV are parallel to geological strike, which is reflected by the ridges along the northern and southern sides of the valley. Groundwater occurs under water table conditions at the site. The saturated zone generally extends into residuum a few feet above bedrock.

Potentiometric data for monitoring wells at the Rust Garage Facility are presented in Table C.1. Mapping of the potentiometric groundwater surface at the Rust Garage Facility, based on water level measurements obtained from monitoring wells GW-508, GW-631, GW-632, and GW-634, during November 1993 and April 1994, indicate that groundwater generally flows from north/northwest to south/southeast across the site (Figures C.2 and C.3). This flow direction is in part influenced by the joint and fracture orientations within the underlying bedrock, and generally coincides with the topographic slope found at the site. In addition, with minor exceptions, water level data from monitor well pairs and clusters in the East Fork Regime indicates vertically upward hydraulic gradients in the area of the Y-12 Plant. Based on the slug testing analyses previously discussed in Section C.1.a of this document, the hydraulic gradient at the Rust Garage Facility was determined to be $0.07 \mathrm{~cm} / \mathrm{cm}$, with an average linear velocity equal to $14.5 \mathrm{ft} / \mathrm{yr}$.

\section{C.2 Surrounding Land}

\section{C.2.a and b Groundwater recharge area and rate}

See Section C.1.b and $c$ of this document for discussion of groundwater recharge area and recharge rate for the East Fork Regime.

\section{C.2.c Hydrology (groundwater flow gradient, direction, and the occurrence of main aquifers or water bearing zones)}

Groundwater in the East Fork Regime occurs in two broad units with fundamentally different hydrologic characteristics: the Knox Aquifer and the ORR Aquitards. The Knox Aquifer is comprised of the Knox Group and the underlying Maynardville Limestone formation of the Conasauga Group. The bulk permeability in the Knox Group, which is due primarily to solution conduits, is ten times greater than that of the ORR Aquitards. The pattern of flow in the ORR Aquitards is toward the Maynardville Limestone, suggesting that this formation is a hydrologic drain for the groundwater flow system in the regime. Flow in the Maynardville is generally along strike toward the east end of the Y-12 Plant. At the east end of the regime, flow directions apparently diverge with one component of flow to the north 
following Upper East Fork Poplar Creek (UEFPC) through a water gap in Pine Ridge, and another flow component to the east along strike in the Maynardville Limestone.

The remaining Conasauga Group formations, the underlying Rome Formation, and the Chickamauga Group form the ORR Aquitards. Flow in the aquitards is controlled by short, intersecting fractures in a relatively impermeable matrix, and most groundwater flows through a thin zone near the water table. Most of the waste-management sites in the East Fork Regime (including the Rust Garage Facility) are underlain by the ORR Aquitards in which contaminant migration rates relative to groundwater flow velocities are reduced by diffusive exchange between matrix and fractures.

The lithologic composition of the Conasauga Group also plays an important role in the occurrence and movement of groundwater in the East Fork Regime. The Nolichucky Shale, which underlies the Maynardville Limestone and forms the bedrock at the Rust Garage Facility, is comprised of approximately $500 \mathrm{ft}$ of massive to thinly bedded shale and siltstone with interbedded limestone. In comparison to the Maynardville Limestone (average hydraulic conductivity equal to $12.8 \mathrm{ft} /$ day), the hydraulic conductivity of the Nolichucky Shale is very low, differing little from that of the underlying Maryville Limestone (average hydraulic conductivity equal to $0.3 \mathrm{ft} /$ day) which is composed of $340 \mathrm{ft}$ to $415 \mathrm{ft}$ of thin- to medium-bedded limestone interbedded with calcareous mudstone and siltstone.

The groundwater system in the East Fork Regime generally consists of two zones: an upper zone composed of unconsolidated materials, and a lower bedrock zone consisting of the six formations of the Conasauga Group (Maynardville Limestone, Nolichucky Shale, Maryville Limestone, Rogersville Shale, Rutledge Limestone, and Pumpkin Valley Shale formations). The unconsolidated and bedrock zones in the regime can be considered parts of a single aquifer because there is no distinct confining layer separating the two zones.

Groundwater in the unconsolidated zone occurs under unconfined (water table) conditions. This zone ranges from $10 \mathrm{ft}$ to $40 \mathrm{ft}$ in thickness and consists predominantly of fill placed during construction of the Y-12 Plant and re-routing of the original UEFPC channel. Geotechnical investigations have shown that the fill contains many voids and contains significant amounts of building debris. The nonuniform properties and varying thickness of the fill probably create widely varying hydraulic conditions in the unconsolidated groundwater zone at the Y-12 Plant.

Movement of groundwater in the bedrock zone is restricted to structures such as bedding planes, joints, fractures, and solution cavities. Therefore, groundwater movement in the bedrock is strongly controlled by the orientation and distribution of these features. Joint sets are the most common structural features observed and several studies have identified a predominant joint set that is roughly parallel to bedding strike and dip ( $N 55^{\circ} \mathrm{E}$ and $45^{\circ} \mathrm{SE}$ ), and a second steeply dipping joint set that strikes approximately $\mathrm{N} 10^{\circ} \mathrm{W}$. Dissolution along joints, fractures, and bedding planes in the carbonate units of the Conasauga Group, in particular the Maynardville Limestone, has produced solution cavities that have greatly increased the permeability of these units.

Groundwater in the upper bedrock zone occurs under unconfined conditions, but becomes increasingly confined with depth due to the healing of bedrock fractures and bedding planes. The general pattern of groundwater flow in the bedrock zone is illustrated in Figure C.4. Downward recharge to the groundwater system initially occurs along Pine Ridge and Chestnut Ridge, then flows laterally toward the axis of BCV and finally discharges upward into UEFPC. This conceptualization of groundwater movement is supported by water level data from monitoring well pairs and clusters in the Bear Creek and 
East Fork Regimes, which indicate vertically upward hydraulic gradients (generally less than 0.07 ) along the axis of $\mathrm{BCV}$.

Contour maps of the potentiometric surface in the East Fork Regime, based on water level measurements recorded from January 1993 and August and September 1993, are presented in Figure C.5. An apparent groundwater divide is located just east of the former S-3 Ponds waste-management unit located at the western end of the Y-12 Plant. This divide roughly coincides with the topographic divide between the Bear Creek Regime and the East Fork Regime. In the zone underlying the East Fork Regime, the direction of groundwater movement is southeast along the BCV axis; however, the general lack of monitoring well coverage within the Y-12 Plant precludes a detailed depiction of the water table surface in the East Fork Regime. Furthermore, the potentiometric contours presented in Figure C.5 only indicate the general direction of groundwater movement because the orientation and distribution of bedding planes, joints, fractures, and solution cavities impart a high degree of anisotropy to the bedrock groundwater zone. Although the water table in the East Fork Regime fluctuates throughout the year, the pattern of fluctuation is similar in all wells and the slope of the water table remains essentially unchanged. 


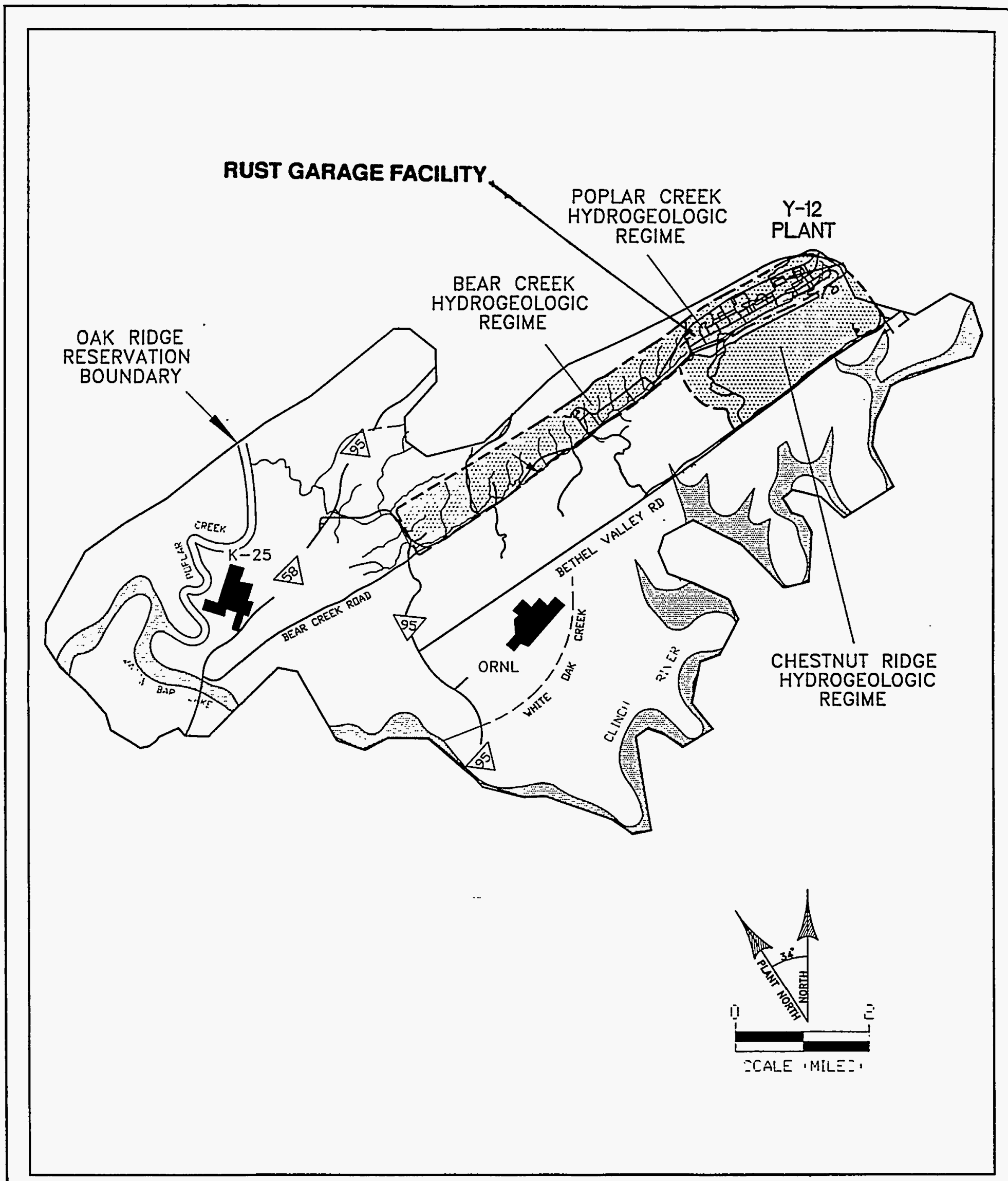

\begin{tabular}{|r|c|c}
\hline LOCATION: & $\begin{array}{c}\text { Y-12 PLANT } \\
\text { OAK RIDGE, Th }\end{array}$ & Figure C.1. \\
\cline { 2 - 2 } DATE: & $2-19-94$ & $\begin{array}{r}\text { Hydrogeologic Regimes at the Y-12 Plant. } \\
\text { DWG ID.: }\end{array}$ \\
\hline OR321-HC & (Source: Y/SUB/94-EAOC10C/2/P7 1994) \\
\hline
\end{tabular}




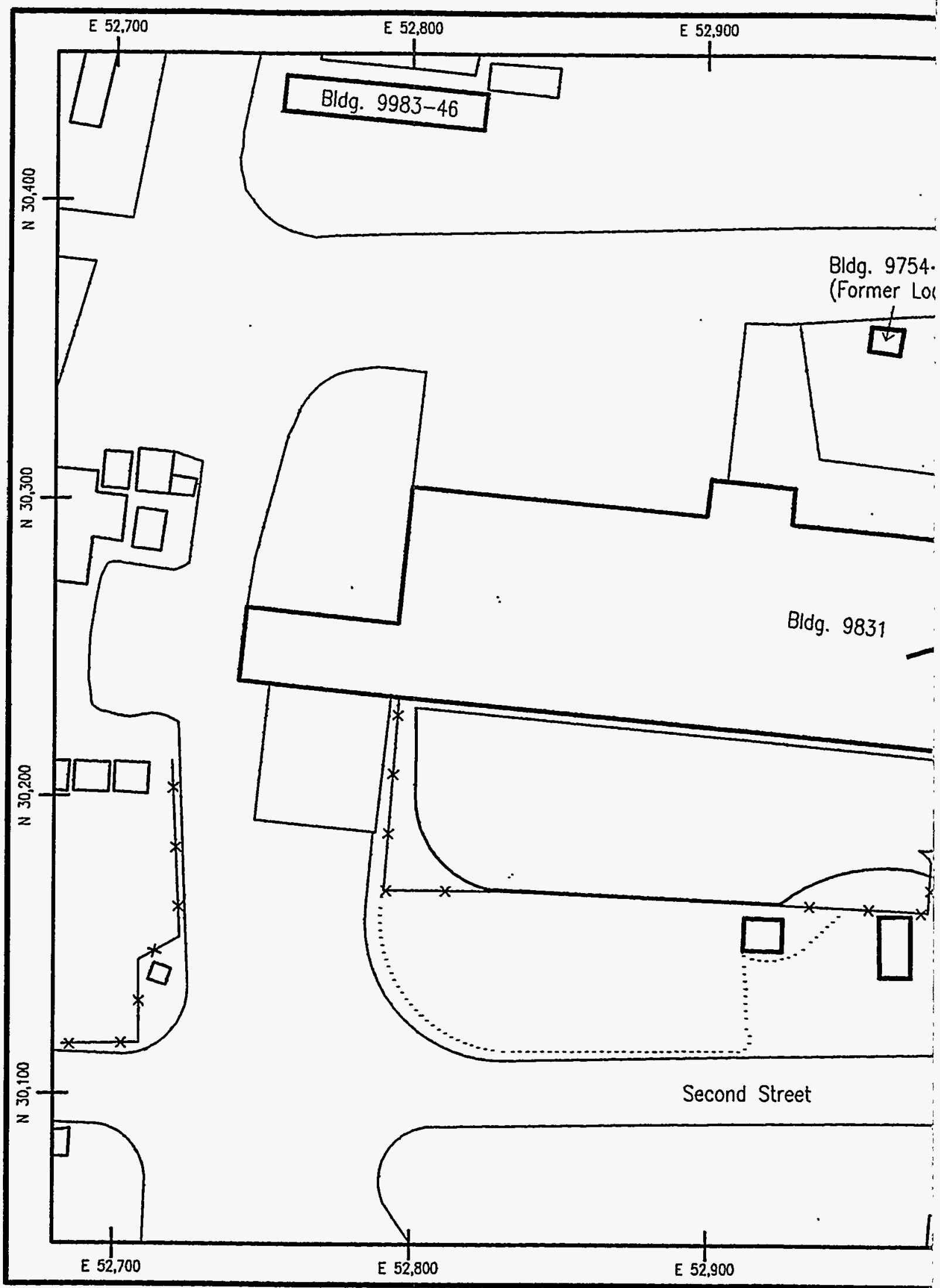

All location information presented in this figure is based upon MMES engineering drawings, results of previous MMES investigations, and/or field determinations of feature and sampling locations. No representotion or warranty, expressed or implied, is made as to the accuracy of the information or stotements presented in this figure.

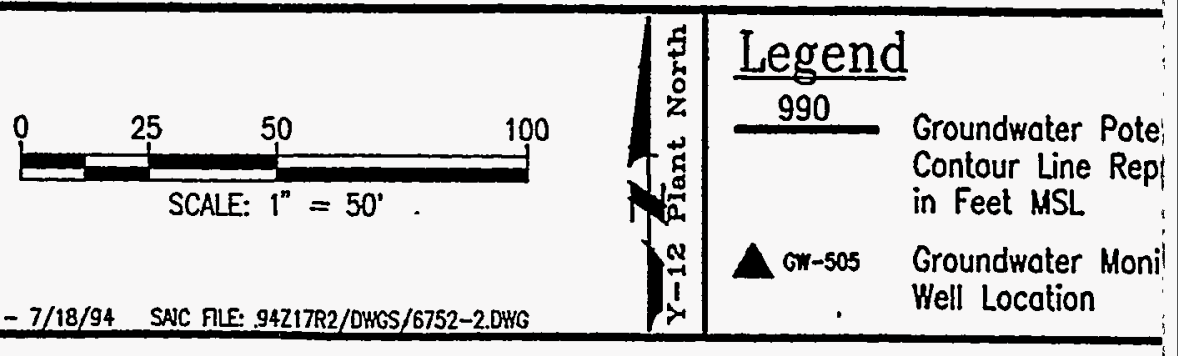




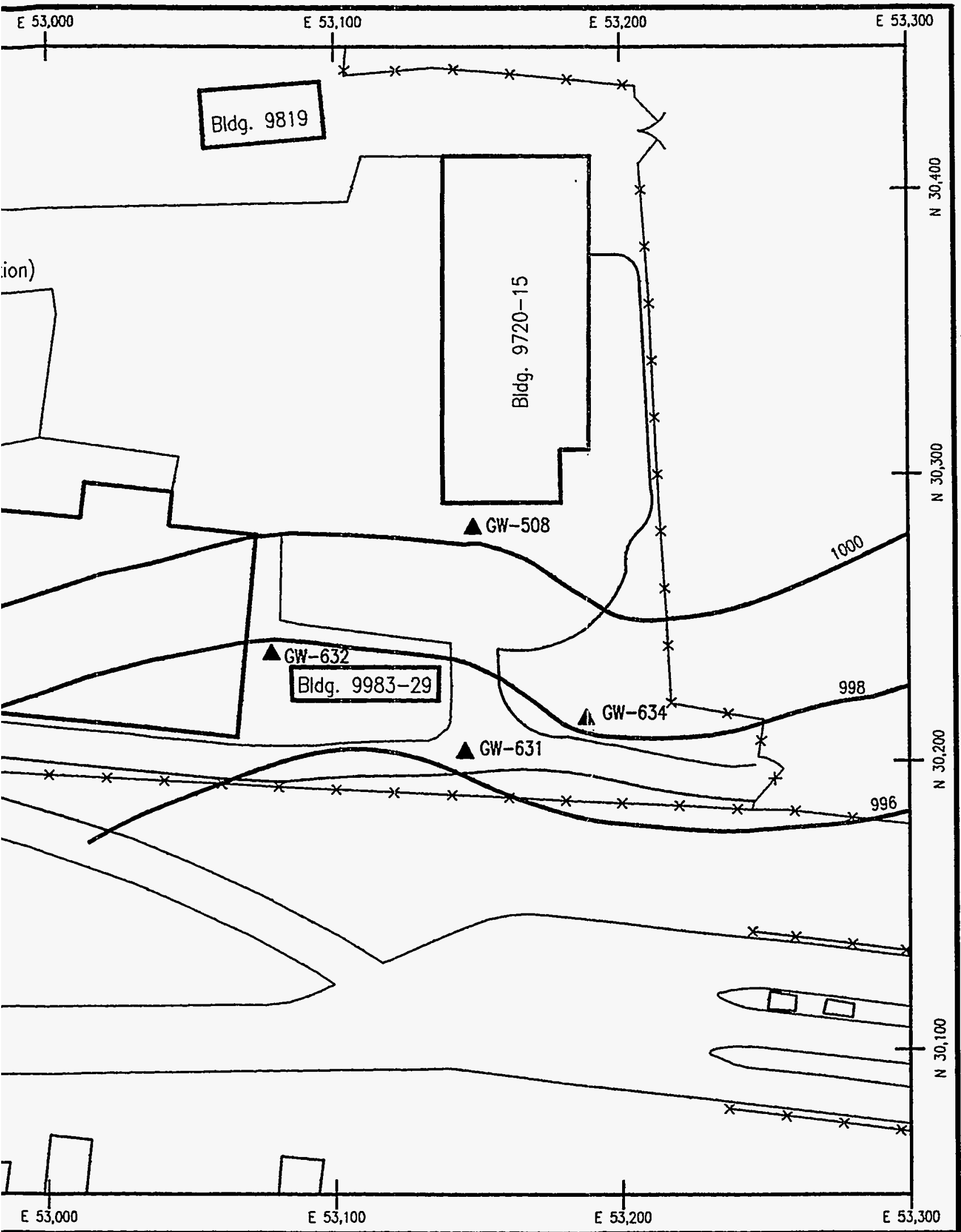

Summary of Measured

Groundwater Elevations (MSL)

GW-508 $1001.15 \mathrm{FT}$.

GW-631 997.14 FT.

GW-632 997.63 FT.

GW-634 998.34 FT.
Martin Marietto Energy Systems, Inc.

Environmental Management Department FIGURE C.2

Rust Garage Facility Site Groundwater Potentiometric Contour Map, November 1993 


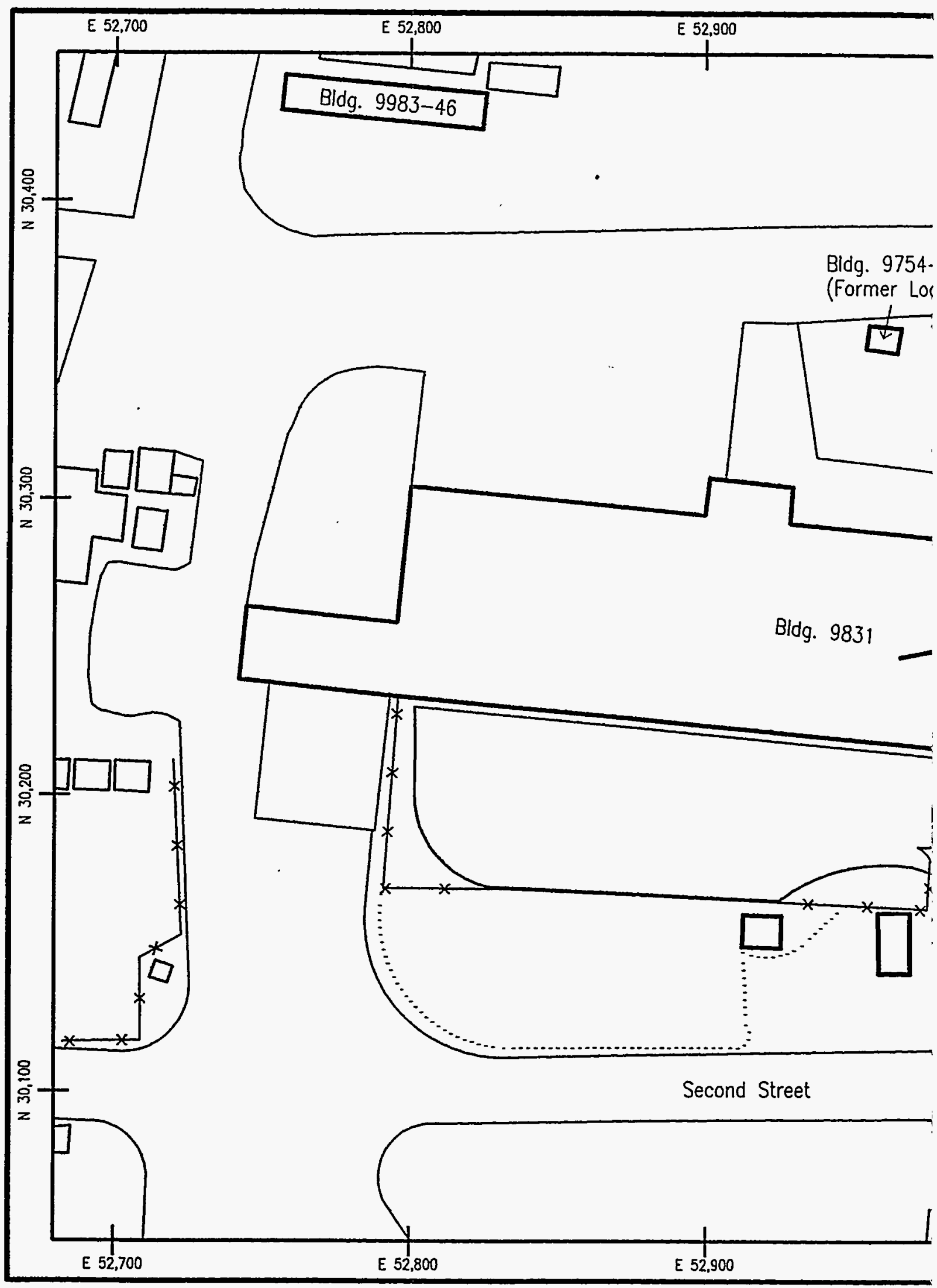

All locotion information presented in this figure is based upon MMES engineering drawings, results of previous MMES investigotions, ond/or field determinations of feature and sompling locations. No representation or worranty, expressed or implied, is made os to the occurocy of the informotion or statements presented in this figure.

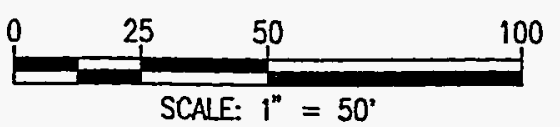

REV. 3 - 7/18/94 SAC FLE: 94Z17R2/OWGS/675POTGW.OFG

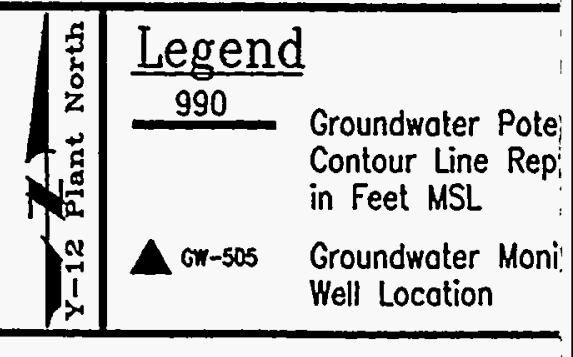




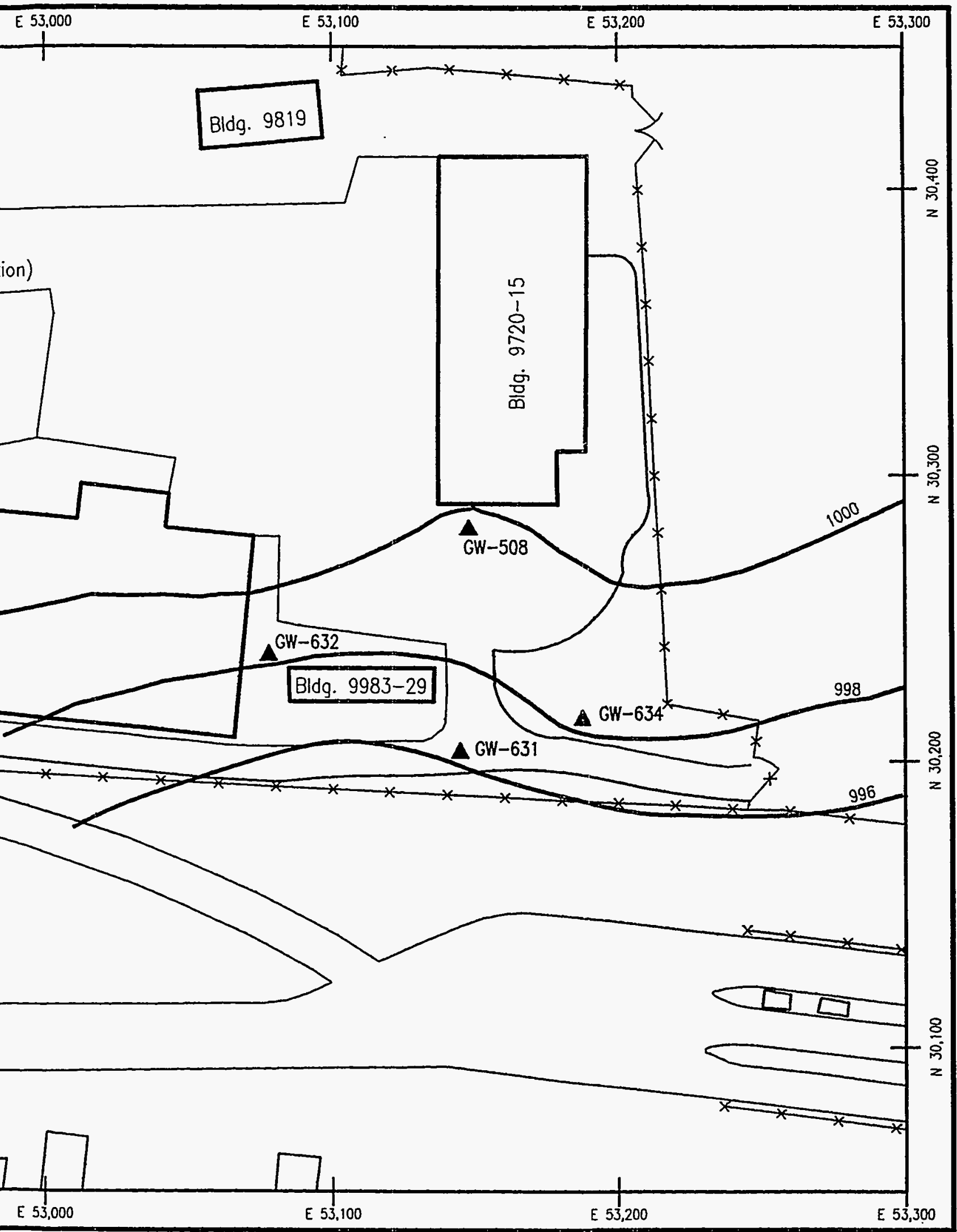

Summary of Meosured

Groundwater Elevations (MSL)

GW-508 $997.57 \mathrm{FT}$.

GW-631 $996.98 \mathrm{FT}$.

GW-632 $998.33 \mathrm{FT}$.

GW-634 $999.34 \mathrm{FT}$.
Mortin Morietto Energy Systems, Inc. Environmental Management Department FIGURE C.3

Rust Garage Facility Site Groundwater Potentiometric Contour Map, April 1994 


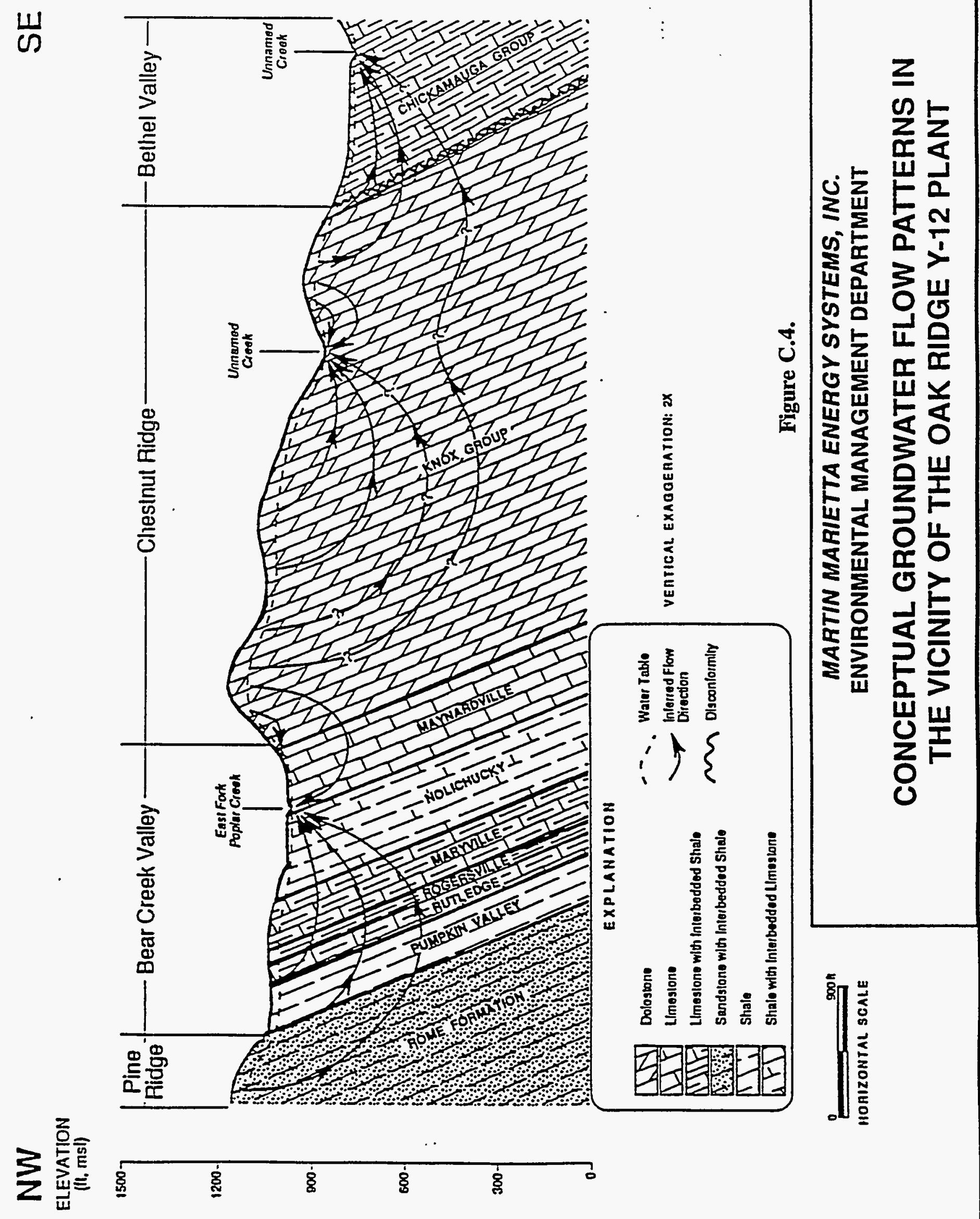




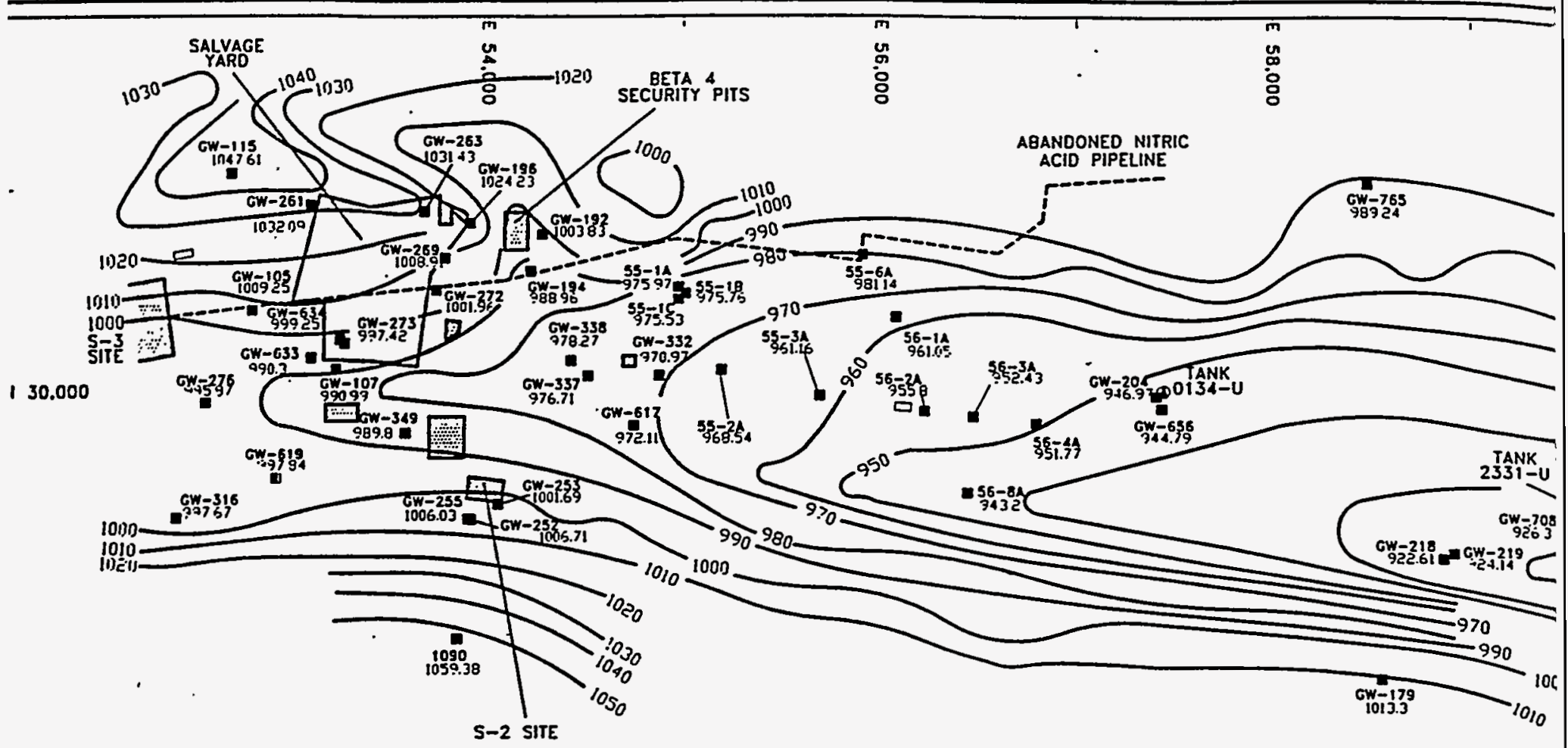

28.000

JANUARY 13:-
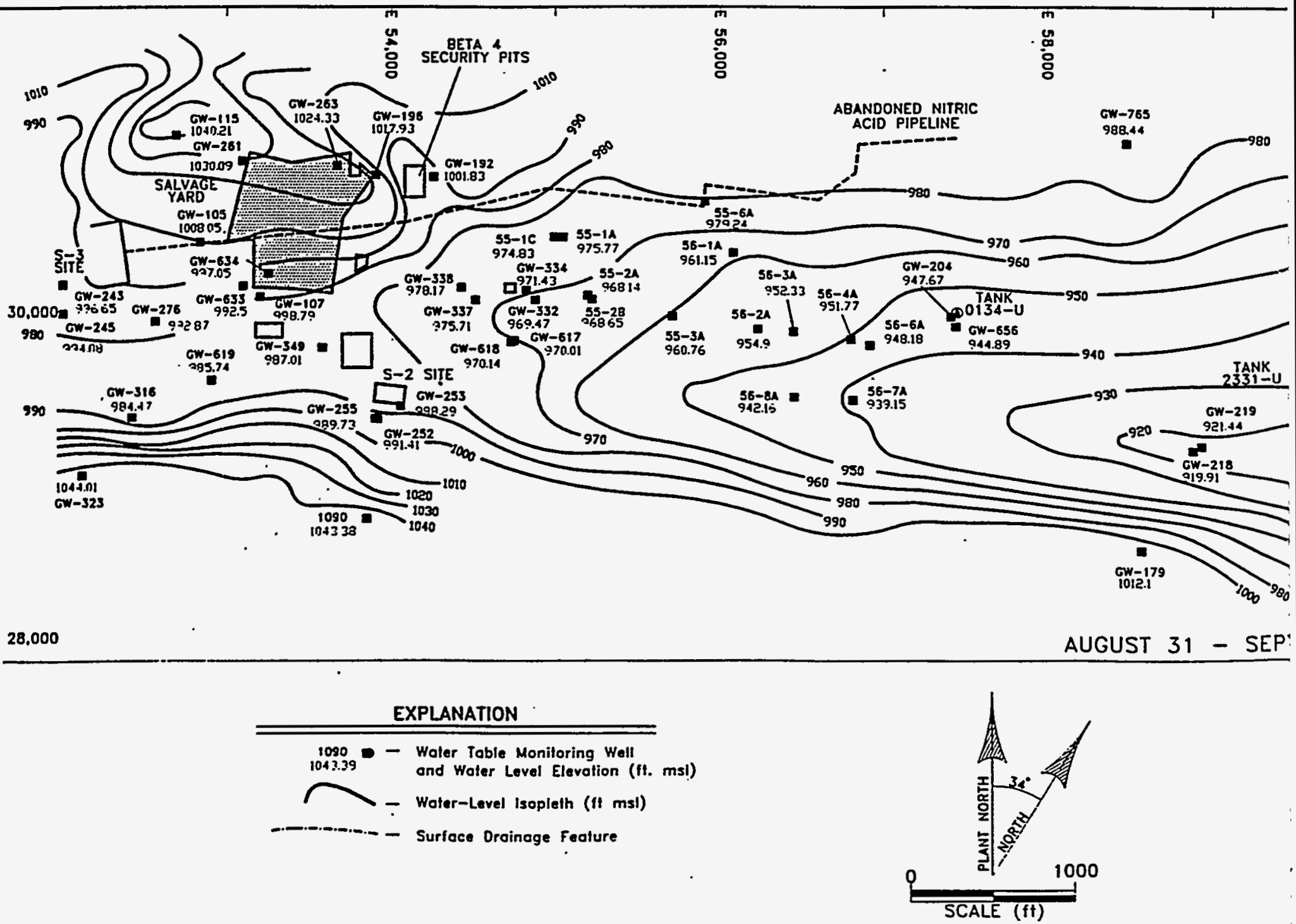
Table C.1. Summary of Groundwater Measurement Information

for Monitoring Wells Located at the Rust Garage Facility

\begin{tabular}{|c|c|c|c|c|c|c|c|}
\hline \multicolumn{8}{|c|}{ for Monitoring Wells Located at the Rust Garage Facility } \\
\hline $\begin{array}{l}\text { Monitoring } \\
\text { Well \# }\end{array}$ & $\begin{array}{c}\text { Date } \\
\text { Measured }\end{array}$ & $\begin{array}{c}\text { Total Well } \\
\text { Depth (BGL) }\end{array}$ & $\begin{array}{c}\text { Top of } \\
\text { Casing (MSL) }\end{array}$ & $\begin{array}{l}\text { Top of Casing } \\
\text { to Water (BTOC) }\end{array}$ & $\begin{array}{l}\text { Ground Surface } \\
\text { To Water (BGL) }\end{array}$ & $\begin{array}{l}\text { Potentiometric } \\
\text { Surface (MSL) }\end{array}$ & $\begin{array}{l}\text { Averaged Water } \\
\text { Elevation (MSL) }\end{array}$ \\
\hline GW-105 & $\begin{array}{l}4 / 25 / 88 \\
2 / 22 / 89 \\
5 / 17 / 89 \\
9 / 13 / 89 \\
12 / 6 / 89 \\
4 / 29 / 91 \\
1 / 93 \\
8 / 93\end{array}$ & $\begin{array}{l}17.0 \mathrm{ft} \\
17.0 \mathrm{ft} \\
17.0 \mathrm{ft} \\
17.0 \mathrm{ft} \\
17.0 \mathrm{ft} \\
17.0 \mathrm{ft} \\
17.0 \mathrm{ft} \\
17.0 \mathrm{ft}\end{array}$ & $\begin{array}{l}1017.35 \mathrm{ft} \\
1017.35 \mathrm{ft} \\
1017.35 \mathrm{ft} \\
1017.35 \mathrm{ft} \\
1017.35 \mathrm{ft} \\
1017.35 \mathrm{ft} \\
1017.35 \mathrm{ft} \\
1017.35 \mathrm{ft}\end{array}$ & $\begin{array}{c}8.35 \mathrm{ft} \\
7.25 \mathrm{ft} \\
9.75 \mathrm{ft} \\
8.65 \mathrm{ft} \\
8.45 \mathrm{ft} \\
11.70 \mathrm{ft} \\
8.1 \mathrm{ft} \\
9.3 \mathrm{ft}\end{array}$ & $\begin{array}{l}5.06 \mathrm{ft} \\
3.96 \mathrm{ft} \\
6.46 \mathrm{ft} \\
5.36 \mathrm{ft} \\
5.16 \mathrm{ft} \\
8.41 \mathrm{ft} \\
4.81 \mathrm{ft} \\
6.01 \mathrm{ft}\end{array}$ & $\begin{array}{l}1009.00 \mathrm{ft} \\
1010.10 \mathrm{ft} \\
1007.60 \mathrm{ft} \\
1008.70 \mathrm{ft} \\
1008.90 \mathrm{ft} \\
1005.65 \mathrm{ft} \\
1009.25 \mathrm{ft} \\
1008.05 \mathrm{ft}\end{array}$ & $1008.41 \mathrm{ft}$ \\
\hline GW-106 & $\begin{array}{l}2 / 21 / 89 \\
5 / 17 / 89 \\
9 / 12 / 89 \\
12 / 5 / 89 \\
1 / 93 \\
8 / 93\end{array}$ & $\begin{array}{l}75.0 \mathrm{ft} \\
75.0 \mathrm{ft} \\
75.0 \mathrm{ft} \\
75.0 \mathrm{ft} \\
75.0 \mathrm{ft} \\
75.0 \mathrm{ft}\end{array}$ & $\begin{array}{l}1016.01 \mathrm{ft} \\
1016.01 \mathrm{ft} \\
1016.01 \mathrm{ft} \\
1016.01 \mathrm{ft} \\
1016.01 \mathrm{ft} \\
1016.01 \mathrm{ft}\end{array}$ & $\begin{array}{l}3.71 \mathrm{ft} \\
5.81 \mathrm{ft} \\
4.81 \mathrm{ft} \\
4.11 \mathrm{ft} \\
4.1 \mathrm{ft} \\
5.4 \mathrm{ft}\end{array}$ & $\begin{array}{l}2.0 \mathrm{ft} \\
4.1 \mathrm{ft} \\
3.1 \mathrm{ft} \\
2.4 \mathrm{ft} \\
2.39 \mathrm{ft} \\
3.69 \mathrm{ft}\end{array}$ & $\begin{array}{l}1012.30 \mathrm{ft} \\
1010.20 \mathrm{ft} \\
1011.20 \mathrm{ft} \\
1011.90 \mathrm{ft} \\
1011.91 \mathrm{ft} \\
1010.61 \mathrm{ft}\end{array}$ & $1011.35 \mathrm{ft}$ \\
\hline GW-107 & $\begin{array}{l}4 / 25 / 88 \\
3 / 3 / 89 \\
5 / 19 / 89 \\
9 / 6 / 89 \\
12 / 6 / 89 \\
4 / 29 / 91 \\
1 / 93 \\
8 / 93\end{array}$ & $\begin{array}{l}14.2 \mathrm{ft} \\
14.2 \mathrm{ft} \\
14.2 \mathrm{ft} \\
14.2 \mathrm{ft} \\
14.2 \mathrm{ft} \\
14.2 \mathrm{ft} \\
14.2 \mathrm{ft} \\
14.2 \mathrm{ft}\end{array}$ & $\begin{array}{l}998.19 \mathrm{ft} \\
998.19 \mathrm{ft} \\
998.19 \mathrm{ft} \\
998.19 \mathrm{ft} \\
998.19 \mathrm{ft} \\
998.19 \mathrm{ft} \\
998.19 \mathrm{ft} \\
998.19 \mathrm{ft}\end{array}$ & $\begin{array}{l}7.49 \mathrm{ft} \\
8.49 \mathrm{ft} \\
8.49 \mathrm{ft} \\
7.19 \mathrm{ft} \\
7.29 \mathrm{ft} \\
9.81 \mathrm{ft} \\
7.2 \mathrm{ft} \\
7.4 \mathrm{ft}\end{array}$ & $\begin{array}{l}5.03 \mathrm{ft} \\
6.03 \mathrm{ft} \\
6.03 \mathrm{ft} \\
4.73 \mathrm{ft} \\
4.83 \mathrm{ft} \\
7.35 \mathrm{ft} \\
4.74 \mathrm{ft} \\
4.94 \mathrm{ft}\end{array}$ & $\begin{array}{l}990.70 \mathrm{ft} \\
989.70 \mathrm{ft} \\
989.70 \mathrm{ft} \\
991.00 \mathrm{ft} \\
990.90 \mathrm{ft} \\
988.38 \mathrm{ft} \\
990.99 \mathrm{ft} \\
990.79 \mathrm{ft}\end{array}$ & $990.27 \mathrm{ft}$ \\
\hline
\end{tabular}


Table C.1 (continued)

\begin{tabular}{|c|c|c|c|c|c|c|c|}
\hline $\begin{array}{c}\text { Monitoring } \\
\text { Well \# }\end{array}$ & $\begin{array}{c}\text { Date } \\
\text { Measured }\end{array}$ & $\begin{array}{c}\text { Total Well } \\
\text { Depth }(B G L)^{1}\end{array}$ & $\begin{array}{c}\text { Top of } \\
\text { Casing (MSL) }\end{array}$ & $\begin{array}{c}\text { Top of Casing } \\
\text { to Water (BTOC) }\end{array}$ & $\begin{array}{l}\text { Ground Surface } \\
\text { To Water (BGL) }\end{array}$ & $\begin{array}{l}\text { Potentiometric } \\
\text { Surface (MSL) }\end{array}$ & $\begin{array}{l}\text { Averaged Water } \\
\text { Elevation (MSL) }\end{array}$ \\
\hline GW-108 & $\begin{array}{l}2 / 22 / 89 \\
5 / 19 / 89 \\
9 / 6 / 89 \\
12 / 6 / 89 \\
1 / 93 \\
8 / 93\end{array}$ & $\begin{array}{l}58.6 \mathrm{ft} \\
58.6 \mathrm{ft} \\
58.6 \mathrm{ft} \\
58.6 \mathrm{ft} \\
58.6 \mathrm{ft} \\
58.6 \mathrm{ft}\end{array}$ & $\begin{array}{l}998.18 \mathrm{ft} \\
998.18 \mathrm{ft} \\
998.18 \mathrm{ft} \\
998.18 \mathrm{ft} \\
998.18 \mathrm{ft} \\
998.18 \mathrm{ft}\end{array}$ & $\begin{array}{l}8.88 \mathrm{ft} \\
7.98 \mathrm{ft} \\
7.98 \mathrm{ft} \\
6.78 \mathrm{ft} \\
8.4 \mathrm{ft} \\
8.7 \mathrm{ft}\end{array}$ & $\begin{array}{l}6.31 \mathrm{ft} \\
5.41 \mathrm{ft} \\
5.41 \mathrm{ft} \\
4.21 \mathrm{ft} \\
5.83 \mathrm{ft} \\
6.13 \mathrm{ft}\end{array}$ & $\begin{array}{l}989.30 \mathrm{ft} \\
990.20 \mathrm{ft} \\
990.20 \mathrm{ft} \\
991.40 \mathrm{ft} \\
989.78 \mathrm{ft} \\
989.48 \mathrm{ft}\end{array}$ & $990.06 \mathrm{ft}$ \\
\hline GW-109 & $\begin{array}{l}3 / 6 / 89 \\
5 / 17 / 89 \\
9 / 11 / 89 \\
12 / 1 / 89\end{array}$ & $\begin{array}{l}147.6 \mathrm{ft} \\
147.6 \mathrm{ft} \\
147.6 \mathrm{ft} \\
147.6 \mathrm{ft}\end{array}$ & $\begin{array}{l}996.99 \mathrm{ft} \\
996.99 \mathrm{ft} \\
996.99 \mathrm{ft} \\
996.99 \mathrm{ft}\end{array}$ & $\begin{array}{l}3.99 \mathrm{ft} \\
4.19 \mathrm{ft} \\
6.39 \mathrm{ft} \\
3.59 \mathrm{ft}\end{array}$ & $\begin{array}{l}1.54 \mathrm{ft} \\
1.74 \mathrm{ft} \\
3.94 \mathrm{ft} \\
1.14 \mathrm{ft}\end{array}$ & $\begin{array}{l}993.00 \mathrm{ft} \\
992.80 \mathrm{ft} \\
990.60 \mathrm{ft} \\
993.40 \mathrm{ft}\end{array}$ & $992.45 \mathrm{ft}$ \\
\hline GW-270 & $\begin{array}{l}4 / 25 / 88 \\
2 / 21 / 89 \\
5 / 15 / 89 \\
9 / 13 / 89 \\
12 / 6 / 89\end{array}$ & $\begin{array}{l}18.4 \mathrm{ft} \\
18.4 \mathrm{ft} \\
18.4 \mathrm{ft} \\
18.4 \mathrm{ft} \\
18.4 \mathrm{ft}\end{array}$ & $\begin{array}{l}1008.96 \mathrm{ft} \\
1008.96 \mathrm{ft} \\
1008.96 \mathrm{ft} \\
1008.96 \mathrm{ft} \\
1008.96 \mathrm{ft}\end{array}$ & $\begin{array}{l}3.56 \mathrm{ft} \\
3.06 \mathrm{ft} \\
5.26 \mathrm{ft} \\
3.86 \mathrm{ft} \\
3.76 \mathrm{ft}\end{array}$ & $\begin{array}{l}0.95 \mathrm{ft} \\
0.45 \mathrm{ft} \\
2.65 \mathrm{ft} \\
1.25 \mathrm{ft} \\
1.15 \mathrm{ft}\end{array}$ & $\begin{array}{l}1005.40 \mathrm{ft} \\
1005.90 \mathrm{ft} \\
1003.70 \mathrm{ft} \\
1005.10 \mathrm{ft} \\
1005.20 \mathrm{ft}\end{array}$ & $1005.06 \mathrm{ft}$ \\
\hline GW-273 & $\begin{array}{l}4 / 25 / 88 \\
1 / 93\end{array}$ & $\begin{array}{l}33.1 \mathrm{ft} \\
33.1 \mathrm{ft}\end{array}$ & $\begin{array}{l}1003.52 \mathrm{ft} \\
1003.52 \mathrm{ft}\end{array}$ & $\begin{array}{l}6.02 \mathrm{ft} \\
6.1 \mathrm{ft}\end{array}$ & $\begin{array}{l}3.84 \mathrm{ft} \\
3.92 \mathrm{ft}\end{array}$ & $\begin{array}{l}997.50 \mathrm{ft} \\
997.42 \mathrm{ft}\end{array}$ & $997.46 \mathrm{ft}$ \\
\hline GW-505 & $4 / 25 / 88$ & $13.5 \mathrm{ft}$ & $1014.78 \mathrm{ft}$ & $5.48 \mathrm{ft}$ & $2.30 \mathrm{ft}$ & $1009.30 \mathrm{ft}$ & $1009.30 \mathrm{ft}$ \\
\hline GW-506 & $4 / 25 / 88$ & $9.5 \mathrm{ft}$ & $1009.99 \mathrm{ft}$ & $6.39 \mathrm{ft}$ & $3.46 \mathrm{ft}$ & $1003.60 \mathrm{ft}$ & $1003.60 \mathrm{ft}$ \\
\hline GW-507 & $4 / 25 / 88$ & $9.0 \mathrm{ft}$ & $1011.28 \mathrm{ft}$ & $7.68 \mathrm{ft}$ & $4.70 \mathrm{ft}$ & $1003.60 \mathrm{ft}$ & $1003.60 \mathrm{ft}$ \\
\hline GW-508 & $\begin{array}{l}4 / 25 / 88 \\
11 / 19 / 93 \\
4 / 5 / 94\end{array}$ & $\begin{array}{l}15.0 \mathrm{ft} \\
15.0 \mathrm{ft} \\
15.0 \mathrm{ft}\end{array}$ & $\begin{array}{l}1012.50 \mathrm{ft} \\
1012.50 \mathrm{ft} \\
1012.50 \mathrm{ft}\end{array}$ & $\begin{array}{l}12.70 \mathrm{ft} \\
11.35 \mathrm{ft} \\
14.93 \mathrm{ft}\end{array}$ & $\begin{array}{r}9.76 \mathrm{ft} \\
8.37 \mathrm{ft} \\
11.95 \mathrm{ft}\end{array}$ & $\begin{array}{r}999.80 \mathrm{ft} \\
1001.15 \mathrm{ft} \\
997.57 \mathrm{ft}\end{array}$ & $999.51 \mathrm{ft}$ \\
\hline GW-509 & $4 / 25 / 88$ & $9.0 \mathrm{ft}$ & $1009.51 \mathrm{ft}$ & $5.71 \mathrm{ft}$ & $2.72 \mathrm{ft}$ & $1003.80 \mathrm{ft}$ & $1003.80 \mathrm{ft}$ \\
\hline
\end{tabular}


Table C.1 (continued)

\begin{tabular}{|c|c|c|c|c|c|c|c|}
\hline $\begin{array}{c}\text { Monitoring } \\
\text { Well \# }\end{array}$ & $\begin{array}{c}\text { Date } \\
\text { Measured }\end{array}$ & $\begin{array}{c}\text { Total Well } \\
\text { Depth }(B G L)^{1}\end{array}$ & $\begin{array}{c}\text { Top of } \\
\text { Casing (MSL) }\end{array}$ & $\begin{array}{l}\text { Top of Casing } \\
\text { to Water (BTOC) }\end{array}$ & $\begin{array}{l}\text { Ground Surface } \\
\text { To Water (BGL) }\end{array}$ & $\begin{array}{l}\text { Potentiometric } \\
\text { Surface (MSL) }\end{array}$ & $\begin{array}{l}\text { Averaged Water } \\
\text { Elevation (MSL) }\end{array}$ \\
\hline GW-631 & $\begin{array}{l}5 / 6 / 90 \\
11 / 17 / 93 \\
4 / 5 / 94\end{array}$ & $\begin{array}{l}16.0 \mathrm{ft} \\
16.0 \mathrm{ft} \\
16.0 \mathrm{ft}\end{array}$ & $\begin{array}{l}1003.99 \mathrm{ft} \\
1003.99 \mathrm{ft} \\
1003.99 \mathrm{ft}\end{array}$ & $\begin{array}{l}8.74 \mathrm{ft} \\
6.85 \mathrm{ft} \\
7.01 \mathrm{ft}\end{array}$ & $\begin{array}{l}8.86 \mathrm{ft} \\
6.97 \mathrm{ft} \\
7.13 \mathrm{ft}\end{array}$ & $\begin{array}{l}995.25 \mathrm{ft} \\
997.14 \mathrm{ft} \\
996.98 \mathrm{ft}\end{array}$ & $996.46 \mathrm{ft}$ \\
\hline GW-632 & $\begin{array}{l}5 / 6 / 90 \\
4 / 29 / 91 \\
11 / 18 / 93 \\
4 / 5 / 94\end{array}$ & $\begin{array}{l}15.0 \mathrm{ft} \\
15.0 \mathrm{ft} \\
15.0 \mathrm{ft} \\
15.0 \mathrm{ft}\end{array}$ & $\begin{array}{l}1005.73 \mathrm{ft} \\
1005.73 \mathrm{ft} \\
1005.73 \mathrm{ft} \\
1005.73 \mathrm{ft}\end{array}$ & $\begin{array}{l}9.30 \mathrm{ft} \\
7.48 \mathrm{ft} \\
8.10 \mathrm{ft} \\
7.40 \mathrm{ft}\end{array}$ & $\begin{array}{l}9.5 \mathrm{ft} \\
7.68 \mathrm{ft} \\
8.32 \mathrm{ft} \\
7.62 \mathrm{ft}\end{array}$ & $\begin{array}{l}996.43 \mathrm{ft} \\
998.25 \mathrm{ft} \\
997.63 \mathrm{ft} \\
998.33 \mathrm{ft}\end{array}$ & $997.66 \mathrm{ft}$ \\
\hline GW-633 & $\begin{array}{l}5 / 7 / 90 \\
1 / 93 \\
8 / 93\end{array}$ & $\begin{array}{l}15.0 \mathrm{ft} \\
15.0 \mathrm{ft} \\
15.0 \mathrm{ft}\end{array}$ & $\begin{array}{l}996.50 \mathrm{ft} \\
996.50 \mathrm{ft} \\
996.50 \mathrm{ft}\end{array}$ & $\begin{array}{l}7.35 \mathrm{ft} \\
6.2 \mathrm{ft} \\
4.0 \mathrm{ft}\end{array}$ & $\begin{array}{l}7.37 \mathrm{ft} \\
6.22 \mathrm{ft} \\
4.02 \mathrm{ft}\end{array}$ & $\begin{array}{l}989.15 \mathrm{ft} \\
990.30 \mathrm{ft} \\
992.50 \mathrm{ft}\end{array}$ & $990.65 \mathrm{ft}$ \\
\hline GW-634 & $\begin{array}{l}5 / 7 / 90 \\
4 / 29 / 91 \\
1 / 93 \\
8 / 93 \\
11 / 18 / 93 \\
4 / 5 / 94\end{array}$ & $\begin{array}{l}15.0 \mathrm{ft} \\
15.0 \mathrm{ft} \\
15.0 \mathrm{ft} \\
15.0 \mathrm{ft} \\
15.0 \mathrm{ft} \\
15.0 \mathrm{ft}\end{array}$ & $\begin{array}{l}1007.15 \mathrm{ft} \\
1007.15 \mathrm{ft} \\
1007.15 \mathrm{ft} \\
1007.15 \mathrm{ft} \\
1007.15 \mathrm{ft} \\
1007.15 \mathrm{ft}\end{array}$ & $\begin{array}{c}8.22 \mathrm{ft} \\
8.30 \mathrm{ft} \\
7.9 \mathrm{ft} \\
10.1 \mathrm{ft} \\
8.81 \mathrm{ft} \\
7.97 \mathrm{ft}\end{array}$ & $\begin{array}{r}8.38 \mathrm{ft} \\
8.46 \mathrm{ft} \\
8.05 \mathrm{ft} \\
10.26 \mathrm{ft} \\
8.97 \mathrm{ft} \\
8.13 \mathrm{ft}\end{array}$ & $\begin{array}{l}998.93 \mathrm{ft} \\
998.85 \mathrm{ft} \\
998.25 \mathrm{ft} \\
997.05 \mathrm{ft} \\
998.34 \mathrm{ft} \\
999.18 \mathrm{ft}\end{array}$ & $998.43 \mathrm{ft}$ \\
\hline GW-635 & $5 / 7 / 90$ & $15.0 \mathrm{ft}$ & $994.85 \mathrm{ft}$ & $3.55 \mathrm{ft}$ & $3.55 \mathrm{ft}$ & $991.30 \mathrm{ft}$ & $991.30 \mathrm{ft}$ \\
\hline
\end{tabular}

1 BGL - Below Ground Level

${ }^{2}$ MSL - Mean Sea Level

${ }^{3}$ BTOC - Below Top of Casing

Table Information Source: (Y-12 Plant Environmental Assessment Plan, July 1988)

(Y-12 Plant Groundwater Quality Assessment, February 1990, 1992, 1994)

(Corrective Action Plan for the Rust Garage Facility, April 1992) 


\section{Provide the Proximity, Quality, and Current and Future Use of Groundwater}

D.1 The groundwater classification of the aquifer or water source (i.e., drinking water supply or nondrinking water supply) as required in the EAG

According to the TDEC groundwater classification procedure, any affected aquifer or water source that fails to meet any of the Primary or Secondary Drinking Water Standards as defined in TDEC Rule 1200-5-1, and is not a drinking water supply as determined by a groundwater usage survey, may be classified as a nondrinking water supply. However, failure of the aquifer or water source to meet the primary or secondary standards cannot be the result of petroleum contamination (i.e., resulting from UST contaminants) unless such contamination is naturally occurring.

Justification for a nondrinking water source classification for groundwater at the Rust Garage Facility is provided in the CAP (Y/SUB-92-99928C/2). This classification has been approved and recognized by TDEC for three similar UST sites located within the Y-12 Plant.

D.2 Any current and/or future uses of the groundwater within a one-half mile radius of the petroleum site (All well and spring locations shall be indicated on an $8.5 \times 11$ or $11 \times 17$ inch color topographic map.)

Groundwater at the Rust Garage Facility, and within a one-half mile radius of the site, is not considered to be part of a current or future drinking water supply because all facilities at the $Y-12$ Plant are located within the ORR, which is access restricted and within which no drinking water supply wells exist or may be drilled. Spring and seep surveys have been conducted at the Y-12 Plant, and these indicate that no springs are present within a one-half mile radius of the site. Figure D.1 illustrates that no springs or drinking water supply wells are located within one-half mile of the Rust Garage Facility.

Furthermore, as discussed in Section $C$ of this document, groundwater in the East Fork Regime is recharged along Pine Ridge and Chestnut Ridge, flows through the Y-12 Plant area, and eventually discharges to the surface waters of UEFPC. Surface waters exiting the Y-12 Plant are impounded by Lake Reality at the eastern end of the plant, and are regularly monitored prior to being discharged. Based on the characteristics of the East Fork Regime, Pine Ridge acts as a hydrologic divide between the Y-12 Plant, located south of the ridge, and the city of Oak Ridge. Therefore, any drinking water supply wells that may be located in the city of Oak Ridge would be hydrologically isolated from groundwater originating within the East Fork Regime.

\section{D.3 The depth to each aquifer or water bearing zone encountered during the investigation}

The depth to the saturated zone (i.e., water table) at the Rust Garage Facility may be estimated from soil boring logs completed during investigations conducted at the Rust Garage Facility, and the potentiometric surface may be derived from groundwater measurements taken from piezometers and monitoring wells located across the site. Soil boring logs completed during the investigations indicate that wet or moist cuttings were encountered at depths ranging from $3 \mathrm{ft}$ below the ground surface (BGS) to greater than $15 \mathrm{ft}$ BGS (Corrective Action Plan for the Rust Garage Facility, Appendices A, C, and D). Specifically, the boring $\log$ for GW-509 indicates that the borehole produced water at $3 \mathrm{ft}$ BGS. However, borehole 8 (BH-08) was dry at a total depth of $15 \mathrm{ft} \mathrm{BGS.} \mathrm{Due} \mathrm{to} \mathrm{the} \mathrm{presence} \mathrm{of} \mathrm{extensive}$ fill at this site, laterally discontinuous and ephemeral perched zones may be present. Therefore, the 
potentiometric surface may better reflect the depth to groundwater, given the irregular topography and subsurface inhomogeneity at the site.

The most recent measurements (April 1994) of groundwater levels in monitoring wells GW-508, GW-631, GW-632, and GW-634 indicate that the potentiometric surface at the Rust Garage Facility is between 7.13 and $11.99 \mathrm{ft}$ BGS (Table C.1). Additionally, the groundwater level measurement data indicates that the potentiometric surface at the facility slopes downward in elevation from approximately $1000 \mathrm{ft}$ mean sea level (MSL), at the north end of the site, to approximately $996 \mathrm{ft}$ above MSL at the south end of the site. 


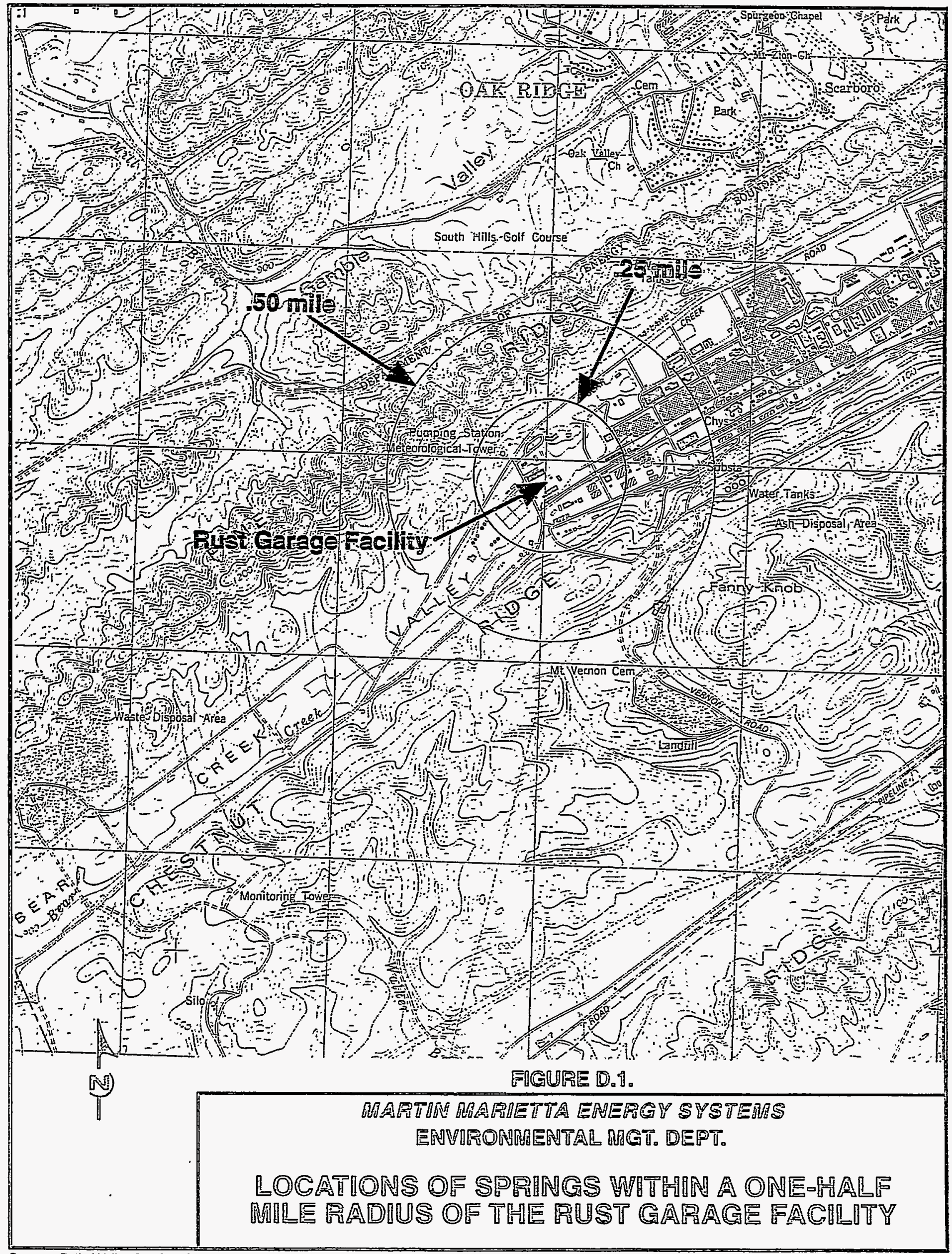




\section{E. Perform an Exposure Assessment}

This section presents a descriptive summary of potential current and future human and ecological exposures to contaminants related to the Rust Garage Facility. An exposure assessment defines the course that a chemical agent takes as it moves from a source to a receptor. An exposure pathway may include:

- a source of potential contamination;

- a mechanism for release from the source (e.g., chemical partitioning from solid to liquid that infiltrates into and through the unit) and a route of migration from the source to a receiving environmental media (e.g., vertical transport through the unsaturated zone to groundwater);

- a point of exposure (e.g., a groundwater well);

- a route of exposure (e.g., ingestion); or

- a receptor.

The integration of these factors results in a complete exposure pathway.

At the Rust Garage Facility, the current contamination source is subsurface soils that have become contaminated via leakage from the petroleum USTs previously located at the site. The primary release and transport mechanisms away from the source to points of exposure in surrounding media include:

- vertical leaching to the groundwater, with continued vertical and horizontal migration through the groundwater;

- vertical/horizontal migration through the storm flow system to surface water;

- $\quad$ runoff to surface water and sediments;

- volatilization into the air; and

- particulate emissions into the air.

Indirect exposure to the contaminated subsurface soils may occur through the pathways summarized below.

E.1 Potential exposure routes including any future change in land use (address as appropriate to site)

\section{E.1.a Groundwater}

\section{E.1.a.i and ii Oral and Dermal}

Potential exposure pathways associated with groundwater contamination at the Rust Garage Facility include:

- ingestion of groundwater;

- inhalation while showering; and

- dermal exposure while bathing.

None of these potential exposure pathways are likely because the groundwater underlying the unit is currently classified as nondrinking water, and no private residences are located within the ORR. It is 
unlikely that a change in groundwater classification and/or usage restrictions will occur prior to degradation of the petroleum constituents.

\section{E.1.b Surface water}

\section{E.1.b.i and ii Oral and Dermal}

Potential exposure pathways associated with surface water contamination at the Rust Garage Facility include:

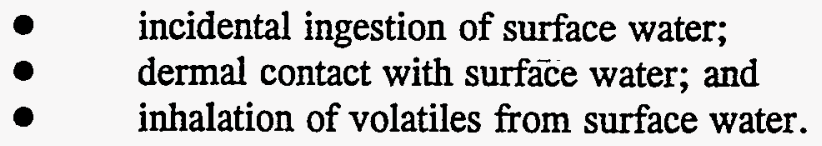

These pathways are most likely to occur in the immediate vicinity of the unit given current land use conditions. However, because the petroleum constituents have such a high tendency to partition into the air (see Table B.3), potential BTX contamination, as well as potential TPH contamination in surface water downgradient of the unit would not be detectable. Further, at the current groundwater flow rate any potentially contaminated groundwater reaching a surface water discharge point would be highly degraded (see Section B.2.b.ii for discussion of fate and transport).

\section{E.1.c Soils}

\section{E.1.c.i and ii Oral and Dermal: (I) Surficial (12 ft or less); and (II) Deep (greater than $12 \mathrm{ft}$ )}

Potential exposure pathways associated with soil contamination at the Rust Garage Facility include:

- incidental ingestion of soil;

- dermal contact with soil

Because the unit is located within an area that is access restricted, and most of the site is covered with asphalt, concrete, or gravel, exposure to soil contamination would be unlikely. Soil contamination is generally limited to subsurface soils, and contact would be limited to excavation or similar activities.

\section{E.1.d Air}

Potential exposure pathways associated with contaminated air at the Rust Garage Facility would include:

- inhalation of volatiles from groundwater, surface water, and/or soils; and

- inhalation of fugitive dust.

Volatilization and particulate emissions from the soil are unlikely due to the depth of the contamination and because most of the site is covered by asphalt, concrete, or gravel. Exposure to contaminants in air would only be likely during excavation or similar activities. This release of particulates would be brief in duration and not significant in terms of exposure via inhalation. No occupied subsurface structures (i.e. basements) where vapors could accumulate exist in the vicinity of the site. Since the groundwater is not potable and not utilized, exposure from the volatilization from groundwater would not be likely. Because the petroleum constituents have such a high tendency to volatilize (see Table B.3) it is unlikely 
that any detectable contamination will remain in the surface water long enough to reach off-site surface water where exposure could occur.

\section{E.2 Potential receptors by exposure route}

In order to determine potential receptors, both current and future potential land use must be considered. Three general types of land use categories that are generally considered during an exposure assessment are residential, industrial, and/or recreational.

The current land use associated with the Y-12 Plant is light industrial. At the present time, the operational period of the Y-12 Plant is projected to be at least 30 years, with an additional passive institutional control period of 100 years. The strategic planning for future use of the government-owned property at the Y-12 Plant is a continuing topic of discussion that will likely be resolved over time. It is anticipated that the results of several Comprehensive Environmental Response, Compensation, and Liability Act (CERCLA) operable unit risk assessments, and cost-benefit analyses performed during CERCLA Feasibility Studies, will help make the decisions concerning future land use. In lieu of a clear understanding of future land use, this exposure assessment adopts the following land use assumptions:

- Soil - government controls remain in place and activity at the unit is light industrial;

- Groundwater - comparatively considered a nondrinking water source (under UST Division guidelines). This is expected to be the water classification for the groundwater underlying and downgradient of the unit, based on the presence of contaminants above the drinking water standard, not related to the release of petroleum product. However, the CERCLA process uses drinking water criteria in facility feasibility studies.

- Surface Water - the surface water body immediately downgradient of the unit is UEFPC which heads approximately 4,500 ft east of the Rust Garage Facility. This feature enters Lake Reality at the eastern end of the Y-12 Plant, and becomes Lower East Fork Poplar Creek (LEFPC) upon exiting the lake. LEFPC flows approximately one-half mile in the ORR then runs through the city of Oak Ridge and extends for an additional 14 miles until it reaches the Clinch River. Water in the creek is never expected to be used as a source for potable water; however, recreational activities currently occur outside of the ORR along the banks of the creek. The most applicable land use scenario for LEFPC is recreational.

\section{E.2.a Humans}

The Y-12 Plant is located at the northeast boundary of the ORR across Pine Ridge from the commercial center of the city of Oak Ridge, which has a population of 27,310. Figure E.1 illustrates the present boundary of the ORR, which includes the Y-12 Plant, and the boundary of the City of Oak Ridge. Employment at the Y-12 Plant, as of January 1992, consisted of 6934 full-time Martin Marietta Energy Systems, Inc. employees and approximately 1000 on-site employees of M-K Ferguson, U.S. Department of Energy, and Oak Ridge National Laboratory. No drinking water supplies are located within the ORR boundary. Pumping stations located on the north bank of Melton Hill Lake at the Clinch River supply water to the various DOE facilities and area municipal water plants. 
The East Tennessee Development District, which includes the city of Oak Ridge, is rural in character. Oak Ridge and other cities in the district are within the 7,500 to 50,000 population range, are incorporated, and have a definite central core that provides major employment and trade opportunities. Of the district's $4,200,800$ acres, approximately $80 \%$ is in the agricultural and forest land use categories. In contrast to the district's general land use patterns, the city of Oak Ridge is an urban center with minimal agricultural activities. Land not owned by the federal government consists of 13,615 acres and is divided into more than 9,500 parcels. Most of this land is either residential or vacant, with over 4,700 acres of the vacant land suitable for housing.

Several types of land use are found in proximity to the ORR. The nearest privately owned residential properties are in the Poplar Springs and Sugar Grove Valley communities, and the city of Oak Ridge. A community within the city of Oak Ridge (the Scarboro community) is located along the north side of Pine Ridge with residences within several hundred feet of the ORR boundary. Relative to ORR boundaries, Poplar Springs is located 2 miles west across the Clinch River, and Sugar Grove Valley is located 1.5 miles north. Agricultural land use includes small-scale private gardening; raising of tobacco, corn, wheat, and soybeans as cash crops; raising of beef cattle; and dairy farming. Some areas are also used for commercial logging.

Recreational areas downstream of the point that Poplar Creek empties into the Clinch River include the Watts Bar Lake Embayment/Clinch River waterway, which is used as a recreational area by both boaters and fisherman; a number of small camping/picnic areas and boat launching ramps; and a public swimming area at Melton Hill Dam. There are no public recreational facilities, except for the previously mentioned boat launching ramp, within 2 miles of the ORR. Sport hunting of game birds and game animals occurs seasonally in the region, and deer hunting is authorized on some parts of the ORR as a conservation measure.

The ORR lies primarily within the corporate limits of the city of Oak Ridge. A buffer zone surrounds each of the facilities in the ORR to provide security, space for expansion, and isolation from the general public. Tracts totaling about 14,000 acres are allocated around operating reactors, waste disposal areas, and streams that receive routine waste releases and burial ground seepages. Acreage used for high-voltage transmission lines, pipelines, transportation corridors, and security fences amounts to about 5,000 acres. Approximately $80 \%$ of the ORR is part of a comprehensive forest management program that divides the ORR into 27 compartments. These compartments range in size from 365 to 1,200 acres. Vegetational features unique to the area are excluded from timber harvest operations, and 40 individual sites are designated for environmental research.

Two factors play a role in limiting the number of potential current receptors to contaminated soils at the Rust Garage Facility. First, the entire Y-12 Plant facility is an access restricted area which is surrounded by fences and guarded by active patrolling. Second, because soil contamination at the Rust Garage Facility is generally located in the subsurface soil, exposure to contamination would only be likely during excavation or similar activities. Institutional controls in place at the Y-12 Plant (such as the requirement for penetration permits) ensure that workers are aware of potential hazards and are appropriately protected. In addition, most of the site is covered by asphalt, concrete pavement, or gravel preventing dust formation and direct contact with soils.

On-site human receptors would include employees or contractor personnel working at the Y-12 Plant. All personnel performing work activities at the plant are required to have extensive training regarding health and safety, waste management practices, and waste hazards: Visitors associated with 
on-going investigation and remediation activities may be present within the Y-12 Plant. However, the frequency of site visits and duration of work efforts by visitors is likely to be small. There is little to no potential for nonemployees to enter the Y-12 Plant area because of the emphasis on security at the facility. No sensitive subpopulations are assumed to exist within the Y-12 Plant area.

Current off-site human receptors for surface water are members of the general public who live downstream of the Y-12 Plant. These current receptors include: members of the public who may contact contaminants in LEFPC outside the Y-12 Plant boundary; users of water in the Clinch River; and recreational users of the Clinch River. Children playing in these locations could be considered to be a sensitive subpopulation. However, it is unlikely that chemicals associated with the Rust Garage Facility will ever reach the surface water due to the high tendency to volatilize and/or degrade (see Table B.3) and the distance from the facility to any surface waters.

\section{E.2.a,b, and c Domestic species, Aquatic species (plants and wildlife), and Terrestrial species (plants and wildlife)}

Identification of ecological receptors differs from the identification of human receptors in that land use and access control do not control the process. Current ecological receptors are assumed to be the same as future receptors in the absence of potential remediation.

Potential exposure pathways may exist for terrestrial organisms. Small mammals, insects, worms, and plants may be directly exposed to contaminated soils, particularly resulting from intrusive activities in the subsurface environment. Terrestrial mammals may be exposed both topically and via soil ingestion. Birds and mammals may feed from contaminated food chains and may ingest soils directly.

Perhaps the most significant pathway for exposure to contaminants is the food web. Feeding habits and other aspects of lifestyle determine the significance of these exposures. For example, shrews prey on earthworms, which may have exterior contamination from adhering soils and may contain ingested soil. Therefore, shrews may ingest more soils than voles, whose diet is mainly vegetarian. Some insects of terrestrial origin spend their entire lives on or in the soil. Plants are highly exposed to contaminants in soils by root uptake and by surface deposition of airborne dust. Animals may in turn feed on the contaminated vegetation. These factors, however, are limited due to the extent that asphalt, concrete, and gravel cover the site.

With regard to aquatic species, potential receptors would be any biota that are present in the waters or sediment of UEFPC. These biota could include fish such as the Central stoneroller (Campostoma anomalum) and the redbreast sunfish (Lepomis auritus), and benthic macroinvertebrates and periphyton. Aquatic or terrestrial predators could include the Belted kingfisher (Megacryle alcyon), Great blue heron (Ardea herodias), or mink (Mustela vison).

With regard to terrestrial species, potential receptors would be any biota that are present at the Rust Garage Facility site. These biota could include the groundhog (Marmota moras), the short-tailed shrew (Blarina brevicauda), and the white-footed mouse (Peromyscus leucopus) who spend much of their time burrowing within ground litter and just below ground surface. Invertebrates such as earthworms (Lumbricus spp) may also be potential receptors of contamination. Although unlikely due to the extent of concrete and asphalt cover, insectivorous birds may be exposed indirectly to the contaminants passed through the food web by consuming the contaminated earthworms. 
There are no domestic species of any type at the Rust Garage Facility or within the confines of the Y-12 Plant. Since much of the site is covered by asphalt and concrete, very little area is currently available for plants and wildlife to reside. Short grasses are currently the only vegetation present at the site. 


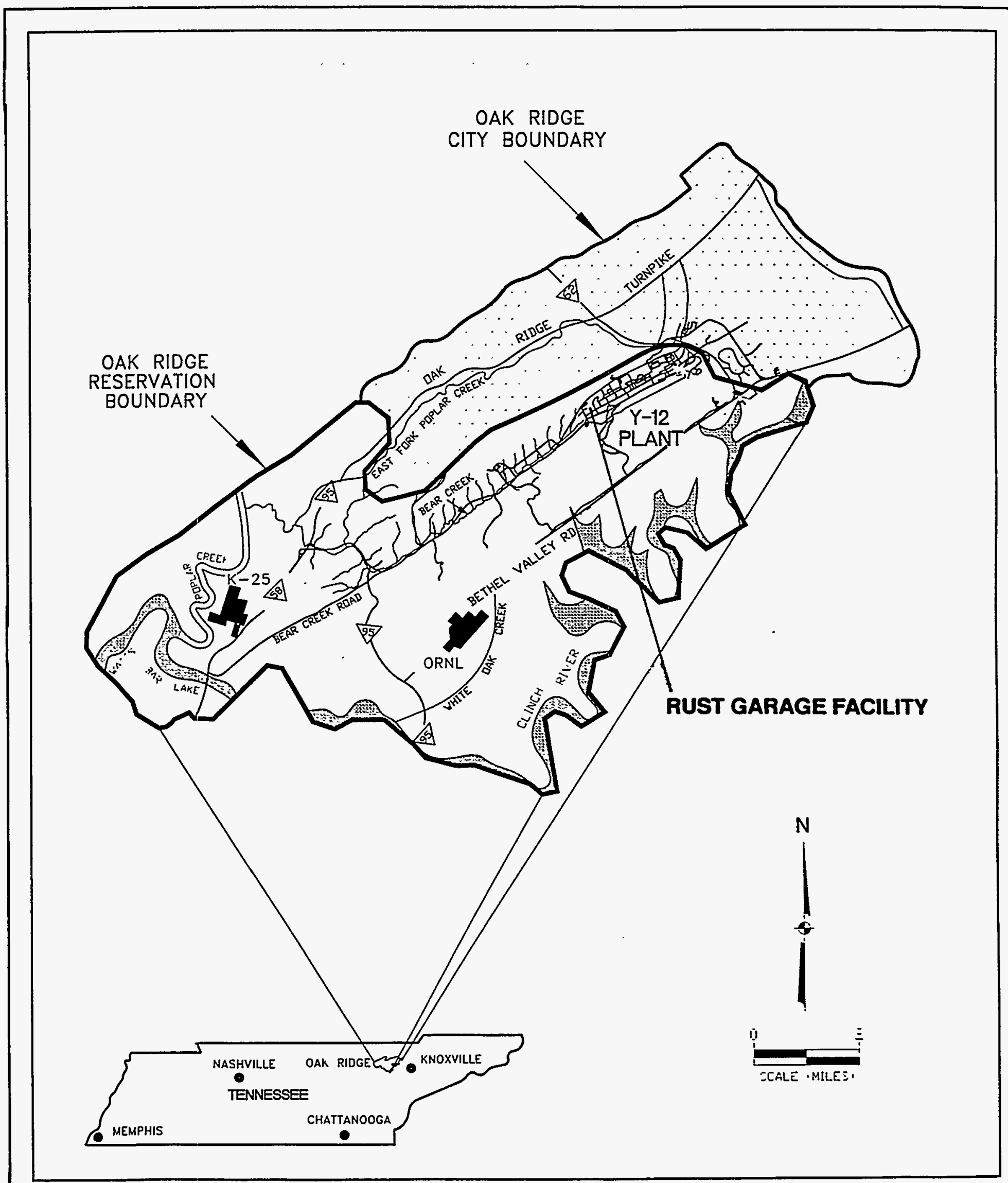

\begin{tabular}{|r|c|}
\hline LOCATION: & $\begin{array}{c}\text { Y-12 PLANT } \\
\text { OAK RIDGE. TN. }\end{array}$ \\
\hline DATE: & $2-15-94$ \\
\hline DWG ID.: & OR250-HC \\
\hline
\end{tabular}

Figure E.1.

Boundaries of the Oak Ridge Reservation and the City of Oak Ridge. (Source: Y/SUB/94-EAQ10C/2/P7) 


\section{F. Provide the Proximity, Quality, and Current and Future Uses of Surface Waters}

F.1 Any surface waters within a one-half mile radius and the site location indicated on a color topographic map (This map shall be on $8.5 \times 11$ or $11 \times 17$ inch paper.)

Four surface water features are located within one-half mile of the Rust Garage Facility. These features include the headwaters of Bear Creek, the first and second uppermost tributaries to Bear Creek (North Tributary 1 and 2 or NT-1 and NT-2) and an unnamed first order drainage south of the Rust Garage Facility. Bear Creek and its tributaries are contained within the Bear Creek Hydrogeologic Regime (Figure F.1), which is separated from the Rust Garage Facility by both a surface water and groundwater divide.- The unnamed drainage south of the Rust Garage Facility lies south of Chestnut Ridge, which also forms a major hydrologic divide within the area.

F.2 Any current and/or future uses of surface waters within a one-half mile radius (i.e., drinking water source, recreation, etc.)

All surface water features within one-half mile of the Rust Garage Facility are contained within the ORR, which is access controlled. Based on the location of these surface water features within the ORR, and potential for these features to receive contaminants via runoff from the Y-12 Plant, it is unlikely that these features would have any future uses (i.e., drinking water source, recreational area, etc.) for at least the next 30 years. 


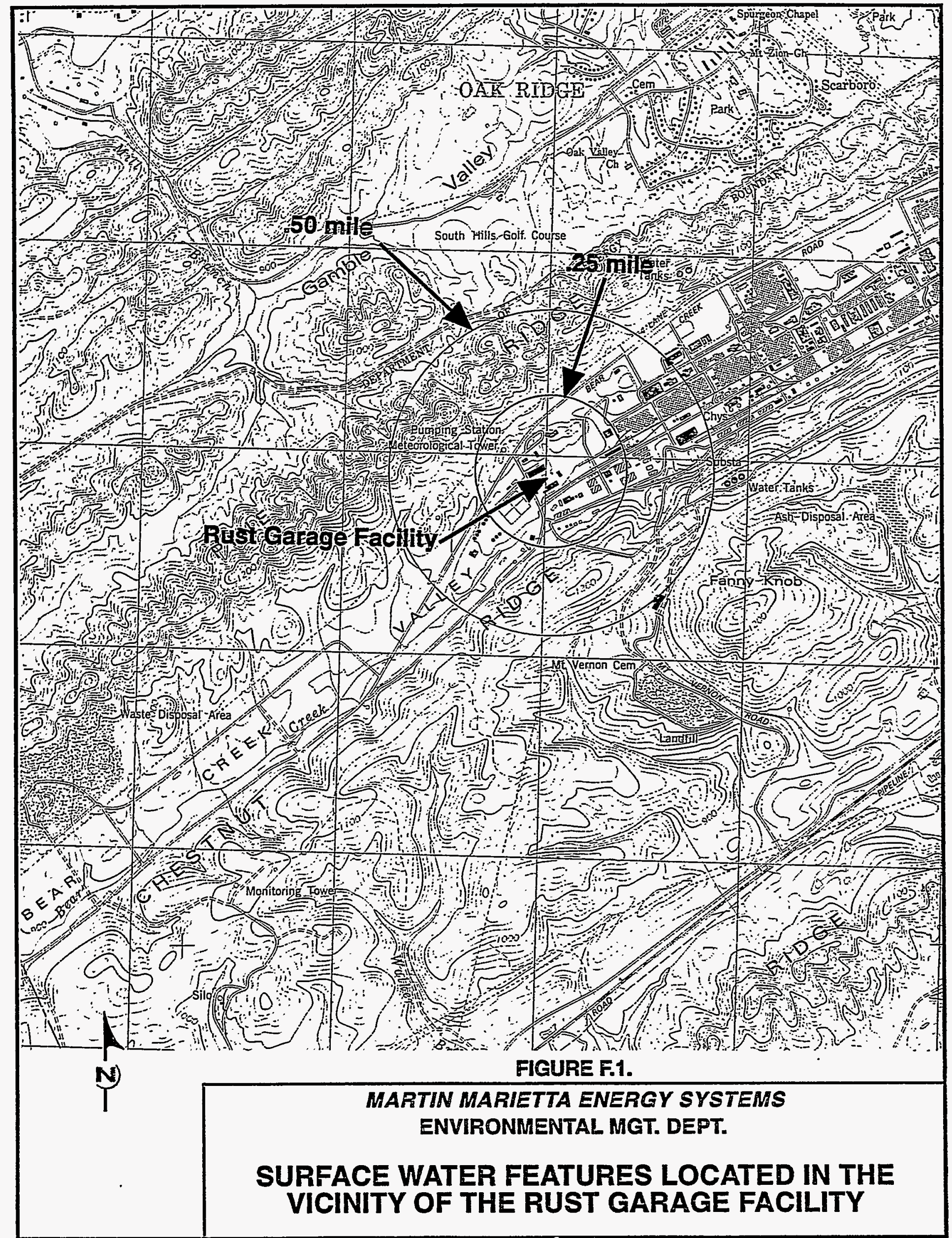




\section{SUMMARY}

S.1 A summary justifying the proposed site-specific cleanup levels based on all available information. The summary must include a discussion of the calculations in Worksheets 1 and 2, the information compiled in the exposure assessment, and all risk(s) (carcinogenic, systemic toxicant, and other) to human health or the environment.

Based on the information presented in this Site-specific Standard Request with regard to evaluation of the physical and chemical characteristics of contaminants present at the Rust Garage Facility, hydrogeologic characteristics of the site and surrounding land, current and future groundwater and surface water uses, and an exposure assessment, the site-specific standards being requested for approval by TDEC are presented in Table A-1.

Contaminants exhibiting concentrations in groundwater that exceed TDEC Criteria Values (Worksheet 1) are benzene and toluene. MTBE was not an analyte of concern at the time investigations were conducted at the Rust Garage Facility; therefore, this constituent was not considered as part of the Systemic Hazard Index. The Carcinogenic Hazard Index for groundwater at the site is calculated to be 1840, and the summed SHI is 3.364. Both of the index results are in excess of a guideline value of 1.0. Analyses of TPH in groundwater also indicate that this contaminant is of potential concern because it has been detected in excess of the applicable TDEC Closure Action Level.

None of the maximum contaminant concentrations in soils are in excess of TDEC Criteria Values (Worksheet 1). The CHI for soil, $12 \mathrm{ft}$ or less, at the Rust Garage Facility is calculated to be $4.58 \times$ $10^{-2}$, and the summed SHI is $3.380 \times 10^{-1}$. The CHI for soils greater than $12 \mathrm{ft}$ is $4.0 \times 10^{-4}$, and the SHI is $1.51 \times 10^{-2}$.

Releases at the Rust Garage facility have not impacted surface water or ambient air quality. Sections of Worksheets 1 and 2 that pertain to these media have therefore been marked as not applicable. Fate and transport modeling of groundwater contamination using the highest observed contaminant concentration, the most mobile constituent (benzene), and highly conservative input parameters indicates that it is extremely unlikely that Rust Garage Facility groundwater contamination will reach the nearest receptor at concentrations detectable in surface water.

The site-specific standards being requested for the Rust Garage Facility (Worksheet 2) are justified based on the following conclusions: (1) Conclusions derived from the exposure assessment indicated that there is no current or near-term future human health risk associated with petroleum contaminants at the site, and that the current and future ecological risks associated with the contaminants would be generally limited to terrestrial species living within the subsurface environment at the site (i.e., earthworms) and plant life that has root systems extending into contaminated media. These conclusions are supported by the observation that the vertical and horizonal extents of both soil and groundwater are limited to the immediate area of the Rust Garage Facility that is located within the access restricted Y-12 Plant. The rate of contaminant migration within the groundwater system at the site is relatively slow (hydraulic gradient $=0.07 \mathrm{~cm} / \mathrm{cm}$, average linear velocity $=14.5 \mathrm{ft} / \mathrm{yr}$ ), and no evidence suggests that groundwater contaminants from the Rust Garage Facility have migrated to any exposure points. Also, as discussed in Section B.2 benzene will be completely degraded before reaching the receptor location. (2) Seasonal fluctuations in contaminant concentration have the potential to occur. The requested concentrations (Worksheet 2) reflect the need to compensate for this possibility. 
The current land use associated with the $\mathrm{Y}-12$ Plant is light industrial. The operational period of the plant is projected to be at least 30 years, with an additional passive institutional control period of 100 years. Thus, potential future residential exposures are not expected to occur for at least 30 years. Based on the degradation coefficient for benzene (the only carcinogenic chemical detected in soils or groundwater at the Rust Garage Facility), it is expected that concentrations of benzene and other contaminant compounds at the site will be substantially reduced prior to expiration of the 30-year plant operational period, and degraded entirely within the timeframe for assumed institutional controls. The reduction of all contaminant levels at the Rust Garage Facility will be aided by various natural mechanisms including volatilization, biodegradation, and aquifer flushing.

S.2 A proposal of the groundwater monitoring wells to be sampled during site status monitoring if the Site-specific Standard Request is approved. Closure monitoring and reporting shall be performed in accordance with TGD-007.

Comprehensive monitoring will be conducted 20 to 30 days after TDEC approves the start of a Monitoring Only Program. Site status monitoring will be conducted semi-annually. The groundwater monitoring wells to be included in the closure monitoring network at the Rust Garage Facility will be wells GW-508, GW-631, GW-632, and GW-634. Both the comprehensive and site status monitoring will involve obtaining water level measurements from the prescribed monitoring wells followed by sampling. In addition, all subsurface structures (i.e., catchment basins, utility and sewer lines, etc.) located within the delineated contamination areas of the site will undergo vapor monitoring. No sampling of springs or drinking water supplies will be conducted because neither of these features exist in the vicinity of or immediately downgradient from the Rust Garage Facility.

Within 30 days after each sample collection event, a report that contains information regarding any problems encountered with site monitoring since the previous report, actions taken to resolve problems, and specific water monitoring information will be prepared and submitted to the appropriate TDEC office. The specific water monitoring information will include potentiometric data in the form of both a table and two potentiometric maps based on data collected for the last two monitoring periods. Groundwater sampling data will be provided in a table for the last four monitoring periods, and laboratory analysis sheets for the most recent sampling event will be attached. A groundwater plume map, a map showing the locations of vapor monitoring points, and a table summarizing vapor monitoring results will also be prepared.

Closure monitoring will be performed at the Rust Garage Facility to determine that groundwater contaminant concentrations at the site remain below the requested site-specific standard levels for one year and will consist of four consecutive quarters of sampling. 
Attachment A

94-098P/120594/Rev. 1 


\section{SITE-SPECIFIC STANDARD REQUEST WORKSHEET 1}

\begin{tabular}{|c|c|c|c|c|c|c|}
\hline \multirow[b]{2}{*}{ Exposure media } & \multirow{2}{*}{$\begin{array}{c}\text { Constituent } \\
\text { released }\end{array}$} & \multirow{2}{*}{$\begin{array}{l}\text { Conc. } \\
\text { requested } \\
\text { (ppm) }\end{array}$} & \multirow{2}{*}{$\begin{array}{l}\text { Criteria } \\
\text { value } \\
\text { (ppm) }\end{array}$} & \multirow{2}{*}{$\begin{array}{l}\text { Conc. } \\
\text { exceeds } \\
\text { criteria? } \\
\text { (yes or no) }\end{array}$} & \multicolumn{2}{|c|}{$\begin{array}{c}\text { Ratio of concentration } \\
\text { to criteria }\end{array}$} \\
\hline & & & & & $\mathrm{CHI}$ & SHI \\
\hline \multirow[t]{5}{*}{ Groundwater } & Benzene & 9.2 & 0.005 & yes & 1840.0 & \\
\hline & Toluen $\theta$ & 26.0 & 10 & yes & & 26 \\
\hline & Ethylbenzene & 22 & 4 & no & & 0.550 \\
\hline & Xylenes & 15.0 & 70 & no & & 0.214 \\
\hline & MTBE* & - & 0.7 & $=$ & & - \\
\hline
\end{tabular}

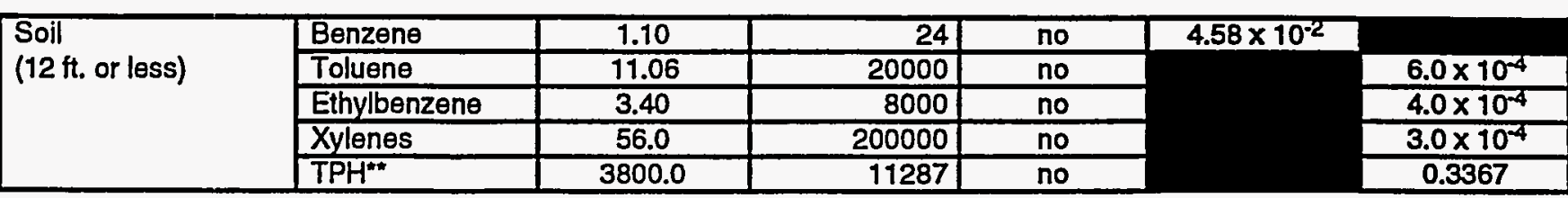

\begin{tabular}{l|l|l} 
SUM & $4.58 \times 10^{-2}$ & 0.3380 \\
\hline
\end{tabular}

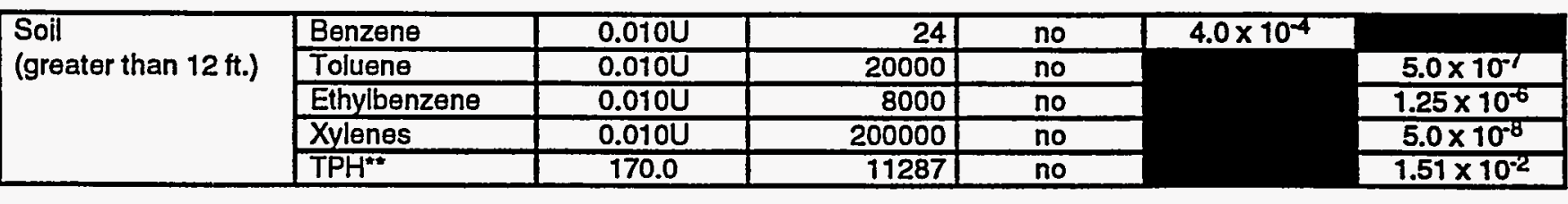

\begin{tabular}{l|l|l} 
SUM & $4.0 \times 10^{-4}$ & 0.0151 \\
\hline
\end{tabular}

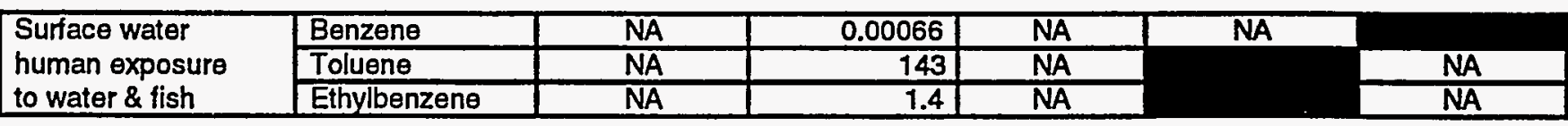

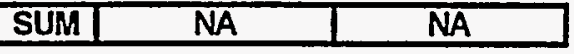

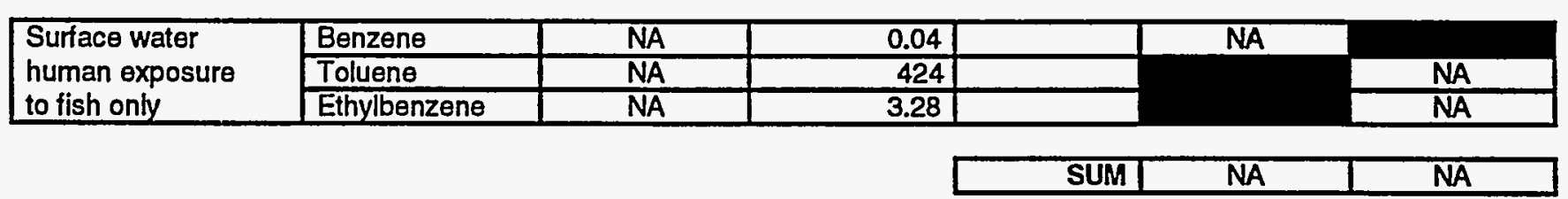

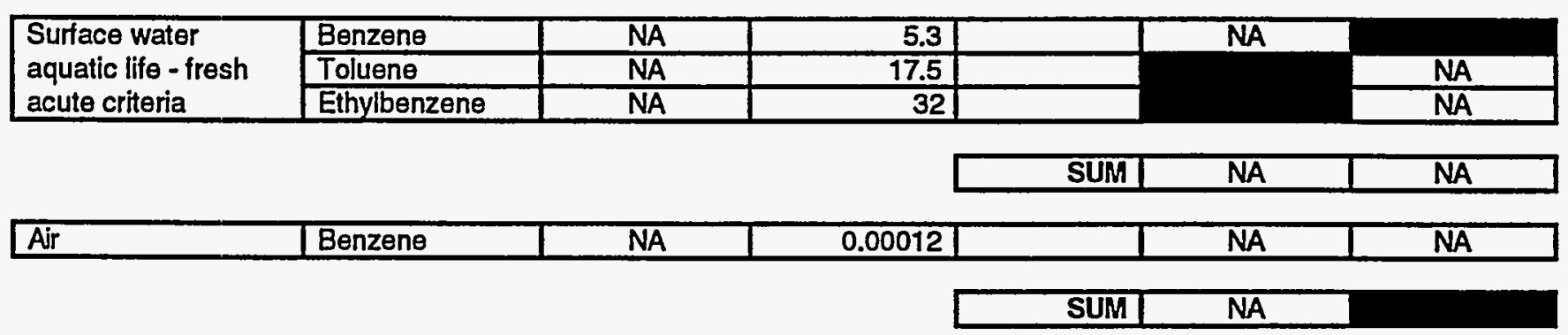

"New Jersey DEPE proposed health-based MCL

"Millner, James, and Nye. "Human Health-based Soil Cleanup Guidelines for Diesel Fuel No. 2." Journal of Soil Contamination. Volume 1/Number 2. 


\section{SITE-SPECIFIC STANDARD REQUEST WORKSHEET 2}

\begin{tabular}{|c|c|c|c|c|c|c|}
\hline \multirow[b]{2}{*}{ Exposure media } & \multirow{2}{*}{$\begin{array}{c}\text { Constituent } \\
\text { released }\end{array}$} & \multirow{2}{*}{$\begin{array}{l}\text { Conc. } \\
\text { requested } \\
\text { (ppm) }\end{array}$} & \multirow{2}{*}{$\begin{array}{l}\text { Criteria } \\
\text { value } \\
\text { (ppm) }\end{array}$} & \multirow{2}{*}{$\begin{array}{l}\text { Conc. } \\
\text { exceeds } \\
\text { criteria? } \\
\text { (yes or no) }\end{array}$} & \multicolumn{2}{|c|}{$\begin{array}{l}\text { Ratio of concentration } \\
\text { to criteria }\end{array}$} \\
\hline & & & & & $\mathrm{CHI}$ & SHI \\
\hline \multirow[t]{6}{*}{ Groundwater } & Benzene & 19 & 0.005 & yes & 3800 & \\
\hline & Toluene & 46 & 10 & yes & & 4.6 \\
\hline & Ethylbenzene & 7 & 4 & yes & & 1.75 \\
\hline & Xylenes & 70 & 70 & no & & 1 \\
\hline & MTBE & - & 0.7 & - & & - \\
\hline & & & & SUM & 3800 & 7.35 \\
\hline \multirow{5}{*}{$\begin{array}{l}\text { Soil } \\
\text { (12 ft. or less) }\end{array}$} & Benzene & 1.10 & 24 & no & $4.58 \times 10^{-2}$ & \\
\hline & Toluene & 11.06 & 20000 & no & & $6.0 \times 10^{-4}$ \\
\hline & Ethylbenzene & 3.40 & 8000 & no & & $4.0 \times 10^{-4}$ \\
\hline & Xylenes & 56.0 & 200000 & no & & $3.0 \times 10^{-4}$ \\
\hline & $\mathrm{TPH}^{* \star}$ & 3800.0 & 11287 & no & & 0.3367 \\
\hline & & & & SUM & $4.58 \times 10^{-2}$ & 0.3380 \\
\hline
\end{tabular}

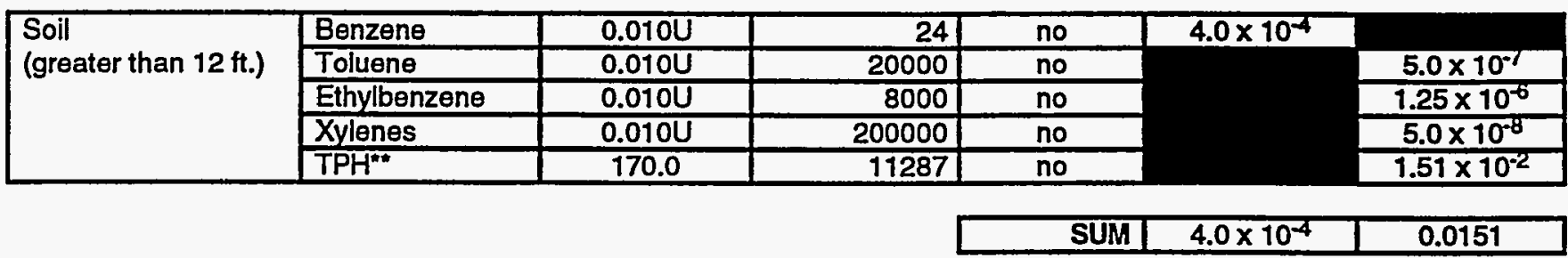

\begin{tabular}{|l|l|l|r|r|r|}
\hline $\begin{array}{l}\text { Surface water } \\
\text { human exposure } \\
\text { to water \& fish }\end{array}$ & Benzene & NA & 0.00066 & NA & NA \\
\cline { 2 - 6 } & Toluene & NA & 143 & NA & NA \\
\cline { 2 - 6 } & Ethylbenzene & NA & 1.4 & NA & NA \\
\hline
\end{tabular}

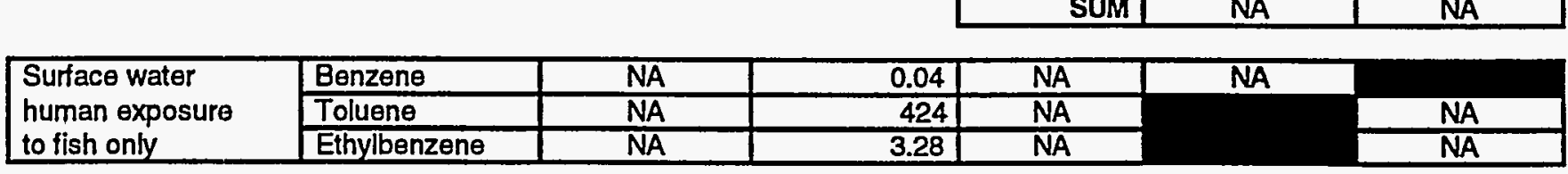

\begin{tabular}{|c|c|c|}
\hline SUM & NA & NA \\
\hline
\end{tabular}

\begin{tabular}{|l|l|r|r|r|r|r|}
\hline $\begin{array}{l}\text { Surface water } \\
\text { aquatic life - fresh } \\
\text { acute criteria }\end{array}$ & Benzene & NA & 5.3 & NA & NA \\
\cline { 2 - 6 } & Toluene & NA & 17.5 & NA & NA \\
\cline { 2 - 6 } & Ethylbenzene & NA & 32 & NA & NA \\
\hline Air & Benzene & NA & 0.00012 & NA & NA \\
\hline
\end{tabular}
\begin{tabular}{|l|l|l|l|}
\hline \\
\hline
\end{tabular}

"New Jersey DEPE proposed health-based MCL

"Millner, James, and Nye. "Human Health-based Soil Cleanup Guidelines for Diesel Fuel No. 2." Journal of Soil Contamination. Volume 1/Number 2. 


\section{Attachment B}

94-098P/120594/Rev. 1 
- Contaminant migration from source to receptor

D fact $=1.0000$ Leachate Conc. $(\mathrm{mg} / \mathrm{l})=.10000+01$

NORMALIZBD CONCENTRATION AT A DISTANCE RROM THE SOURCB

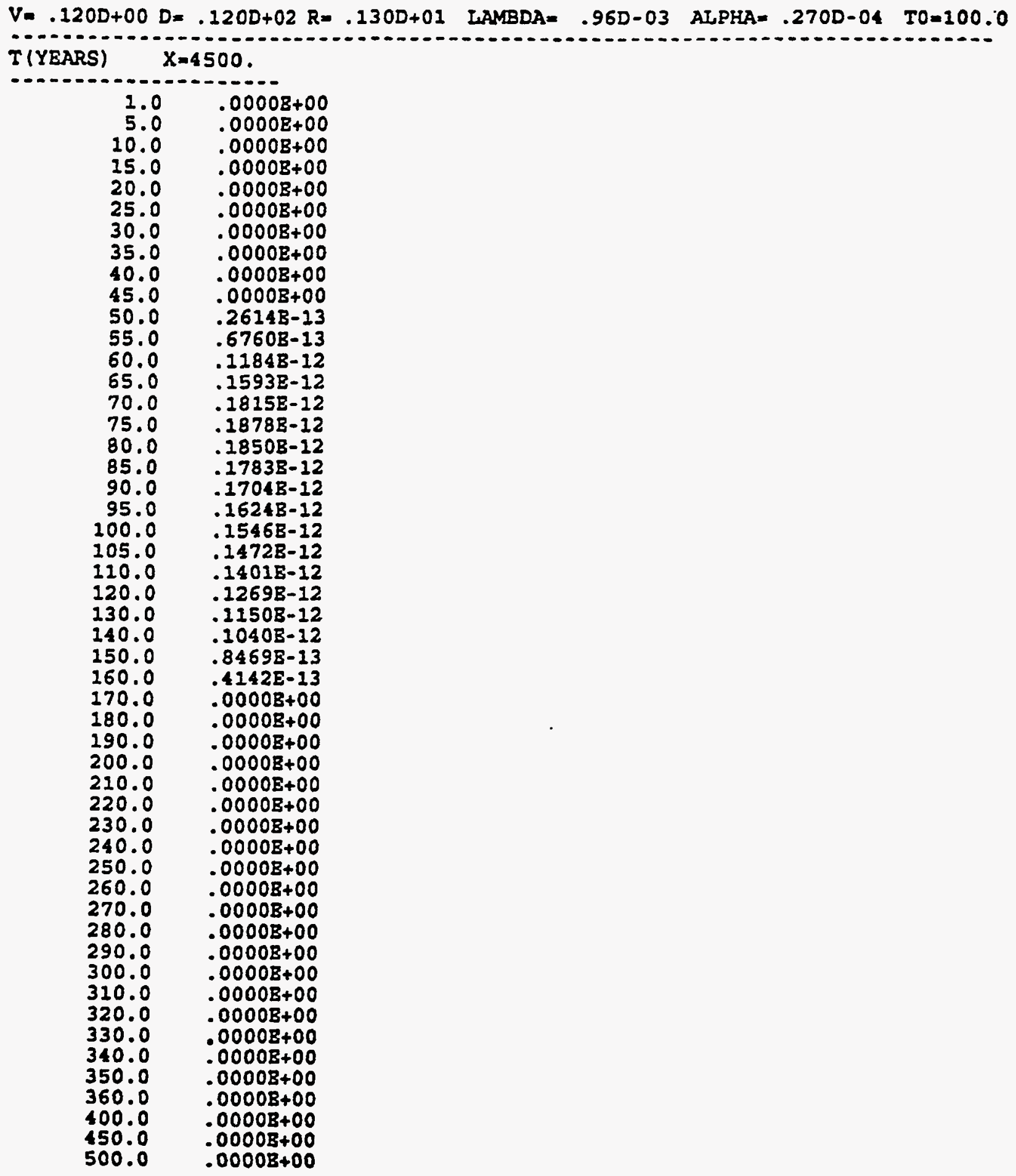


- Contaminant migration from source to receptor

D fact $=1.0000$ Leachace Conc. $(\mathrm{mg} / \mathrm{l})=.1000 \mathrm{D}+0 \mathrm{i}$

NORMALIZED CONCENTRATION AT A DISTANCE FROM THE SOURCE

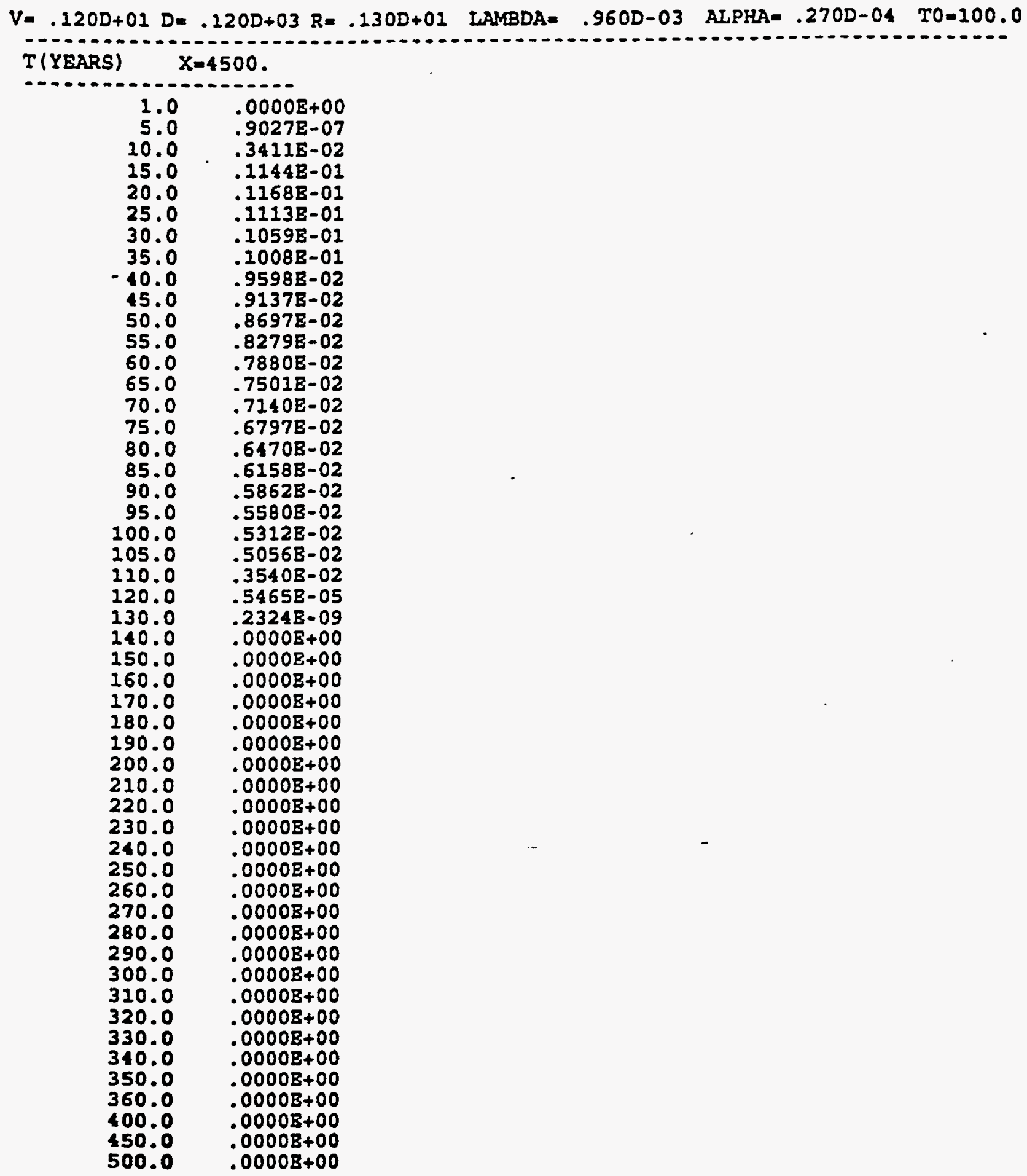


- Contaminant migration from source to receptor

D fact $=1.0000$ Leachate Conc. $(\mathrm{mg} / 1)=.10000+01$

NORMALIZED CONCENTFATION AT A DISTANCE EROM THB SOURCE

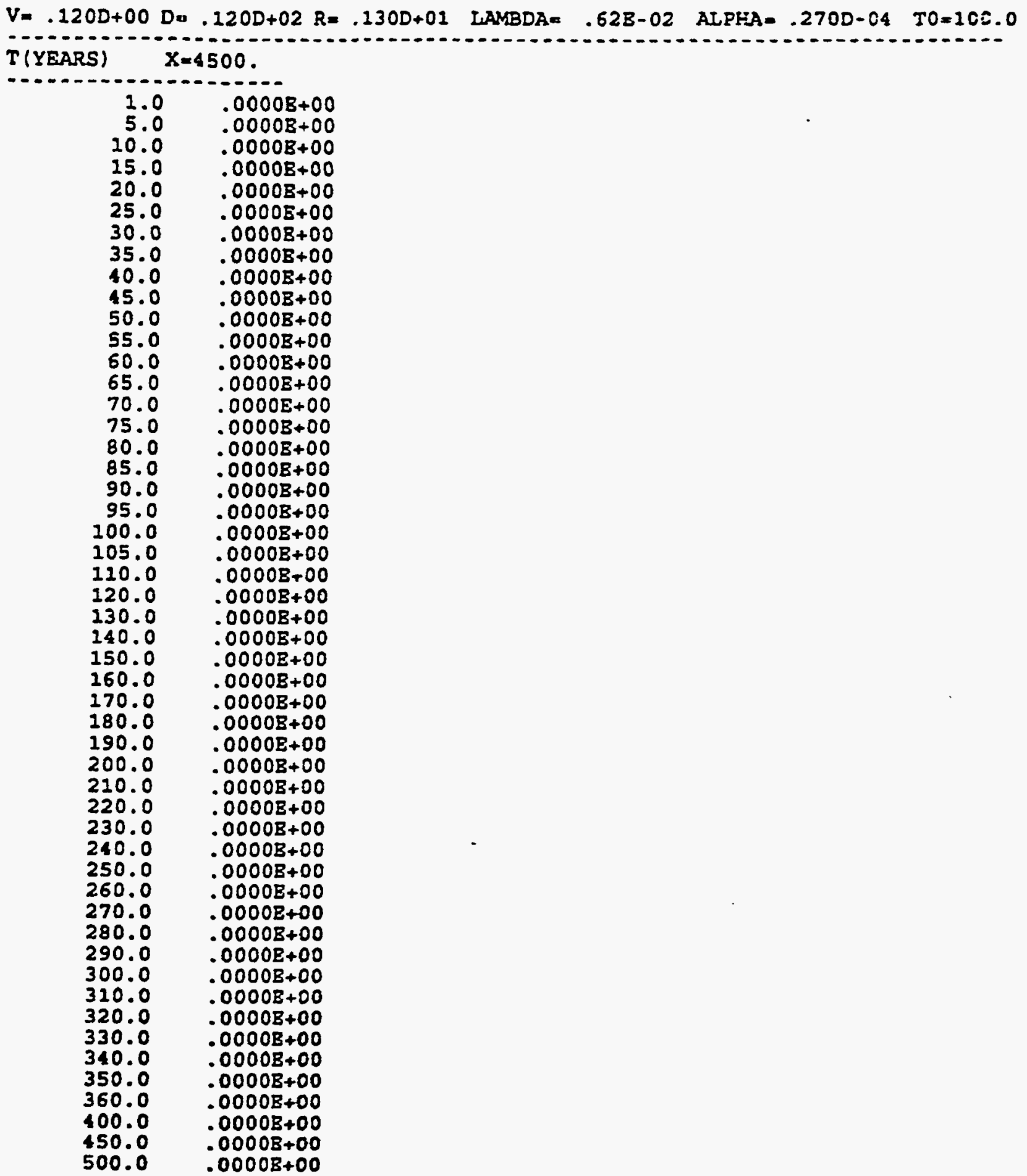




\section{DISTRIBUTION}

HEALTH, SAFETY, ENVIRONMENT, AND ACCOUNTABILITY ORGANIZATION

D.E. Bohrman (2)

L.L. Cunningham/E.M. Ingram

L.W. McMahon

File - EMD - RC

\section{U.S. DEPARTMENT OF ENERGY}

E.M. Atkins

R.J. Spence/W.G. McMillan

S.R. Lankford

A.K. Lee/DOE-OSTI (2)

Y-12 Central Files

ENVIRONMENTAL COMPLIANCE

ORGANIZATION

S.H. Welch

TENNESSEE DEPARTMENT OF ENVIRONMENT AND CONSERVATION

C. Head

E.C. Leming/J.D. Harless 